\title{
SDGs 세부목표와 인권 연계 수준 분석 \\ : 인권기준 및 취약그룹별 접근을 중심으로
}

목차

I. 서론

II. SDGs와 인권간 연계 필요성

1. SDGs에 있어 인권이 갖는 의미 및 중요성

2. 인권에 있어 SDGs가 갖는 의미 및 중요성

3. SDGs와 인권간 통합적 연계 이해의 필요성

III. SDGs 세부목표별 인권기준 연계 현황 분석

1. 분석 방법 및 대상

2. 분석 결과

IV. SDGs 세부목표별 취약그룹 연계 현황 분석

1. 분석 방법 및 대상

2. 분석 결과

V. 향후 활용 방안 및 의의

참고문헌

[부록 1] SDGs 각 세부목표별 국제인권기준 연계 현황 총괄표

[부록 2] SDGs 각 목표별 취약그룹 연계 현황 총괄표 


\section{요 약}

인권과 지속가능발전은 상호의존적이며 함께 강화될 수 있는 관계에 놓여 있다. 따라서 하나의 통합된 방식으로 인권과 지속가능발전을 함께 추구할 수 있도록 두 영역간의 노력과 의무사항들을 하나로 연계함으로써 좀 더 명확하게 할 필요가 있다. 갈수록 증대되는 글로벌 불평등 위기에 대응하여 평등과 비차별(equality and non-discrimination) 인권원칙을 실현하고, '그 누구도 소외되지 않도록(leaving no one behind)' '지속가능 개발을 위한 2030 의제(Transforming our world: the 2030 agenda for sustainable development, 2030 의제)를 현실적으로 이행하기 위해서는, 인권 의무(obligation) 이행과 지속가능개발목표(Sustainable Development Goals, 이하SDGs) 달성 노력(commitments)이 반드시 함께 이루어질 수 있도록 해야 한다.

이러한 문제의식에 공감하여 국제사회에서는 SDGs와 인권간의 통합된 이행방안 마련의 중요성에 대해 국제적 합의가 이루어짐에 따라 두 메커니즘간의 연계를 통한 하나의 접근 방안 모색을 위해 다양한 국제적 시도가 이루어지고 있다.

이에 동 연구에서는 이러한 국제사회의 SDGs와 인권간 연계 노력 의 일환으로서, 덴마크 인권연구소(Danish Institute for Human Rights)가 구축한 데이터베이스를 활용하여 SDGs와 주요 인권기준(human rights instruments)간의 연계성과 함께 SDGs와 주요 취약계층간의 연계성이 어떠한지에 대해 살펴보고자 한다.

동 연구의 목적은 이러한 두 데이터베이스를 활용 및 분석함으로써 SDGs와 인권이 얼마나 상호 긴밀히 연결되어 있는지를 SDGs 세부목표(target) 차원에서 살펴보고, 이를 통해 실제 우리가 인권에 기반한 SDGs 이행 전략을 수립 및 운영하는데 있어 고려하는 각 세부목표가 국제인권기준들과는 어떻게 연결되어 있는지에 대해 살펴봄으로써 SDGs와 인권의 통합적 이해를 도모하는데 있다. 


\section{I . 서론}

인권(human rights)과 지속가능발전(sustainable development)은 상호의존적이며 함께 강화될 수 있는 관계에 놓여 있다. 이에 2015년 9월 국제사회는 오랜 논의를 거쳐 '지속가능개발을

위한 2030 의제(Transforming our world: the 2030 agenda for sustainable development, 이하 2030 의제)'를 공식채택하면서, 동 의제의 가장 주요한 내용 중의 하나로 '그 누구도 소외되지 않도록(leaving no one behind)'하는 동시에 '가장 소외된 사람들에게 가장 최우선적으로 수혜가 갈 수 있도록(reach the furthest behind first)' 함으로써 모두의 인권을 보호하고 증진하는데 전세계의 협력을 도모할 것을 강조하였다. 더욱이 2030 의제는 세계인권선언을 비롯한 인권협약에 의거하여 수립된 바, 2030 의제 자체가 보편적 인권(universal human righs)에 기반하여 수립되었다고 할 수 있다.

아울러 모든 인권은 상호 유기적인 관계를 가지고 있으며, 오늘날 주요하게 도래하고 있는 대양오염 및 기후변화 등과 같은 이슈들 또한 인권의 범주와 연계하여 고려되어야한다는 인식이 확산됨에 따라 인권에 대한 다면적이고 포괄적인 고려와 함께, 이러한 인권이슈에 어떻게 접근 하고 해결할 것인가에 대한 고민 또한 함께 높아지고 있다. 사실상 이러한 이슈들은 대부분 인권 시스템 밖에서 체결된 협정(convention)에 근거하여 다루어진다는 점에서 2030의제는 이러한 기존의 인권시스템을 벗어나 있는 다양한 국제 인권 이슈들을 다루기 위한 하나의 '인권 실현 계획 또는 수단'으로 역할 가능하다.

따라서 갈수록 증대되는 글로벌 불평등 위기에 대응하여 평등과 비차별(equality and nondiscrimination) 인권원칙을 실현하고, '그 누구도 소외되지 않도록(leaving no one behind)' 2030 의제를 현실적으로 이행하기 위해서는, 인권 의무(obligation) 이행과 지속가능개발목표 (Sustainable Development, 이하 SDGs) 달성 노력(commitments)이 반드시 함께 이루어 질 수 있도록 해야 한다.

이러한 문제의식에 공감하여 국제사회에서는 SDGs와 인권간의 통합된 이행방안 마련의 중요성에 대해 국제적 합의가 이루어짐에 따라 두 메커니즘간의 연계를 통한 하나의 접근방안 모색을 위해 다양한 국제적 시도가 이루어지고 있다. 이러한 통합된 연계를 바탕으로 인권기반 접근법을 SDGs 이행에 접목시키는 작업은 결국 SDGs의 달성 노력 자체가 곧 국제인권의무를 이행하는 것과 일치할 수 있도록 하는 방안이기 때문이다. 따라서 이러한 통합된 접근법 마련을 위해서는 국제개발협력 사업 기획 단계에서부터 SDGs 각 세부목표가 어떠한 주요인권기준들에 기반하고 있는지에 대한 사전 이해를 바탕으로 종합적으로 구성해야하며, 이것이 가능할 때 
하나의 일관된 사업 구성 및 운영, 모니터링 및 평가까지도 가능해지는 것이다.

하지만 이러한 연계 시도 자체가 현재로서는 초기 단계이며, 국내 각 국가들의 SDGs 이행 전략 내에 인권 기반 접근을 접목시키는 작업 자체도 현재로서는 초기단계에 있다고 할 수 있다. 현재 덴마크인권연구소(Danish Institute for Human Rights)는 이러한 국제사회의 노력의 일환으로 '인권의 개선과 보호가 SDGs 달성에 어떠한 기여를 하는지, 그리고 SDGs 달성은 위한 노력은 인권실현에 어떻게 기여하는지'에 주목하여 SDGS와 인권간의 연계수준에 대한 일련의 데이터베이스를 구축하였다. 이에 동 연구에서는 덴마크인권연구소가 구축한 데이터 베이스를 활용하여 SDGs와 주요 인권기준(human rights instruments)간의 연계성과 함께 $\mathrm{SDGS}$ 와 주요 취약계층간의 연계성이 어떠한지에 대해 살펴보고자 한다. 물론 동 연구소가 제공하는 데이터베이스의 결과가 자체가 완벽하다고는 할 수 없다. 하지만 이러한 두 메커니즘 간의 연계 작업은 반드시 이루어져야 하며, 이에 대한 국제사회의 노력은 앞으로도 계속 개선되어 가는 과정에 있다는 점에서 현재의 노력 현황을 살펴보고 우리가 SDGS와 인권에 대한 통합적 전략 또는 이행 지침을 마련하거나 사업에 적용하고자 할 때 필요에 따라 적절하게 활용할 수 있어야할 것이다.

이에 동 데이터베이스의 활용을 바탕으로 한 본 연구의 목적은 SDGs와 인권이 얼마나 상호 긴밀히 연결되어 있는지를 SDGs 세부목표(target) 차원에서 살펴봄으로써 실제 우리가 인권에 기반한 SDGs 이행 전략을 수립 및 운영하는데 있어 고려하는 각 세부목표가 국제인권기준들과는 어떻게 연결되어 있는지에 대해 보다 입체적인 고려를 할 수 있도록 하는 것이다. 사실상 현재 국내에서 SDGs의 효과적인 이행을 위해 정부부처 및 실행기관 차원에서의 인권기반접근법을 어떻게 활용하고 정책화, 전략화해가야할지에 대해서는 활발한 논의가 시작되었으나, 사실상 이러한 논의에 앞서 SDGs 메커니즘과 국제인권메커니즘이 그 구성상 얼마나 상호부합하는지에 대한 사전 진단이 보다 구체적으로 먼저 이루어진다면 SDGs 틀 내에서 범이슈로서 인권을 보다 전략적이고 효과적으로 반영할 수 있을 것이기 때문이다.

이에 본 연구는 먼저 왜 SDGs와 인권을 상호 연계하여 이해하고 함께 이행해나가야하는지에 대한 그 필요성을 먼저 살펴보고, 덴마크인권연구소가 제공하는 데이터베이스에 기반하여 $\mathrm{SDGs}$ 와 주요 인권기준간의 연계성, SDGs와 취약계층간의 연계성을 세부목표 수준에서 살펴 본 후 동 분석 결과를 앞으로 어떻게 활용하면 될지에 대해 간략하게 소개하는 순서로 논의를 진행하고자 한다. 


\section{SDGs와 인권간 연계 필요성}

\section{SDGs에 있어 인권이 갖는 의미 및 중요성}

2015년 9월 그간 오랜 논의를 거쳐 공식 채택된 '지속가능개발을 위한 2030 의제(Transforming our world: the 2030 agenda for sustainable development, 이하 2030 의제)'의 가장 주요한 내용 중의 하나가 바로 '그 누구도 소외되지 않도록(leaving no one behind)' 하는 동시에 '가장 소외된 사람들에게 가장 최우선적으로 수혜가 갈 수 있도록(reach the furthest behind first)' 함으로써 모두의 인권을 보호하고 증진하는데 전세계의 협력을 도모하는 것이다. SDGs 출범 이전 전세계가 이행하였던 새천년개발목표(Millennium Development Goals, MDGs)에서는 소외계층에 대한 고려 및 인권 보호가 많이 취약하였다는 반성에 따라 동 2030 의제의 경우 출범 이전부터 SDGs 내 인권 보호 및 증진 내용을 반영하기 위해 다양한 논의 및 노력이 이루어졌으며, 이를 위해 10개 유엔인권협약기구(UN Treaty Bodies)는 2015년 1월 UN총회에서 SDGs가 세계인권선언(Universal Declaration of Human Rights)에 기반을 두어야 한다고 강조한 바 있다(UN, 2015a).

이러한 배경에 따라 2030의제는 지속가능발전을 위해 환경, 사회, 경제적 측면을 하나로 묶음으로써 SDGs 달성을 위한 전세계 다양한 활동 주체들의 헌신적인 노력을 강조하는 동시에 이러한 포괄적인 내용의 발전을 다루면서도 그 중심에는 인권보호 및 증진을 위한 전세계의 협력의 중요성 또한 함께 강조하고 있다. 따라서 '그누구도 소외되지 않도록(leaving no one behind)'해야 한다는 SDGs의 기본 원칙은 2030 의제에서 보여지는 가장 변혁적인(transformative) 요소 중의 하나라고 할 수 있으며, 이는 인권기본원칙 중의 하나인 '평등(equality) 및 비차별 (non-discrimination)' 원칙이 상당히 반영한 부분이라고 할 수 있다(Danish Institute for Human Rights, 2018).

따라서 '그 누구도 소외되지 않도록(leaving no one behind)'하는 동시에 '가장 소외된 사람들에게 가장 최우선적으로 수혜가 갈 수 있도록(reach the furthest behind first)'함으로써 2030 의제는 차별과 불평등 해소에 적극적으로 기여할 수 있으며, 이는 취약계층을 포함한 모든 사회구성원들에게 공평한 발전의 기회를 제공하는 기제로서도 효과적으로 작동할 수 있는 것이다. 이에 2030의제에서는 불평등과 차별(inequality and discrimination) 문제에 대한 적극적인 해결을 위해 SDGs 목표(goals)와 세부목표(targets) 상에 불평등과 차별 이슈를 명시적으로 다루고 있다. 가령 SDG5에서는 성평등을 목표로 설정하고 있으며, SDG10에서는 각국간 또는 
일국 내에서의 불평등 감소를 목표로 하고 있으며, 세부목표 차원에서 보면 SDG5.c, 10.3, 16.b에서 비차별을 위한 법규와 정책 마련 및 강화의 필요성을 강조하고 있다.1)

아울러 이러한 인권에 기반한 2030의제의 특성은 2030의제 내용상에서도 명시적으로 확인된다. 2030의제 전문(preemble)에서는 'SDGs가 모두를 위한 인권 실현을 지향(SDGs aim to "realize the human rights of all”)'한다는 점이 명시되어 있으며, SDGs 세부목표(targets)의 대다수가 세계인권선언(Universal Declaration of Human Rights, UDHR)을 비롯한 주요 국제인권 협약에 근거하고 있는 바,2) 2030의제와 인권은 상호보완적인 관계에 놓여 있음을 확인할 수 있다.3) 특히 인권 협약의 경우 비준을 통해 법적구속력이 발생한다는 점에서 2030 의제가 이러한 법적 구속력이 있는 인권 협약에 근거하고 있다는 것은 인권 규범 및 메커니즘이 2030 의제 이행에 있어 하나의 방향 설정 및 지침으로서 역할할 수 있다고 할 수 있다. 또한 2030 의제가 기반하는 인권 기준(instruments)은 세계인권선언, 국제인권협약(international human rights treaties) 등과 같은 '국제(international)' 차원 뿐만 아니라 지역(regional) 차원에서의 기준들 또한 포괄적으로 포함하고 있으며4) 이러한 국제 및 지역 차원에서의 목표 및 기준들을 국가 정책 및 이행 차원에서도 효과적으로 반영될 수 있도록 촉구하고 있다.5)

1) 각 세부목표의 내용은 다음과 같다. [5.c] 모든 수준에서 성평등과 여성 및 여아의 자력화가 가능하도록 견고한 정책과 시행가능한 법안을 채택하고 강화한다(Adopt and strengthen sound policies and enforceable legislation for the promotion of gender equality and the empowerment of all women and girls at all levels), [10.3] 차별적인 법규,정책, 관례를 철폐하고, 이와 관련한 적절한 법, 정책 및 활동을 증진하는 등의 노력을 포함하여 평등한 기회를 보장하고 결과의 불평등을 감소한다 (Ensure equal opportunity and recude inequalities of outcome including by eliminating discriminatory laws and practices and promoting appropirate legislation, policies and action in this regard), [16.b] 지속가능발전을 위한 비차별적 법규와 정책을 증진하고 강화한다(Promote and enforce non-discriminatory laws and policies for sustainable development).

2) 2030 의제 10항은 다음과 같다. [10항] 이 새로운 의제는 국제법에 대한 완전한 존중을 포함하여, 유엔 헌장의 목적과 원칙에 따른다. 이것은 세계인권선언, 국제인권조약, 새천년선언 및 2005년 세계정상회의 결과에 기반하며, 발전에 대한 권리선언과 같은 기타 국제적 선언문서의 내용에 입각한다 (10. The new Agenda is guided by the purposes and principles of the Charter of the United Nations, including full respect for international law. It is grounded in the Universal Declaration of Human Rights, international human rights treaties, the Millennium Declaration and the 2005 World Summit Outcome. It is informed by other instruments such as the Declaration on the Right to Development.)

3) 이성훈 (2017)에서는 2030 의제 문서 상에서의 인권 언급 현황을 세부적으로 정리하여 소개하고 있다. 따라서 각 동 의제 문서상의 조항별 인권 언급현황에 대한 내용은 이성훈(2017) pp.10-13을 참조하기 바란다.

4) 해당 2030 의제 내 해당 조항은 다음과 같다. [21] 우리는 지속가능발전을 위한 지역차원 뿐만 아니라 지역하위 (subregional) 차원의 고려 또한 중요하게 생각한다. 아울러 지속가능발전을 위한 지역경제 통합 및 상호 연계성 또한 중요하게 인식한다. 지역 및 지역하위 수준의 프레임워크는 국별수준에서 지속가능발전을 위한 정책을 구체적인 행동으로 연결시키는데 주요한 촉진제 역할을 할 수 있다. (We acknowledge also the importance of the regional and subregional dimensions, regional economic integration and interconnectivity in sustainable development. Regional and subregional frameworks can facilitate the effective translation of sustainable development policies into concrete action at the national level.)

5) 해당 2030 의제 내 해당 조항은 다음과 같다. [55] 지속가능개발목표는 통합적이고 불가분하며, 국제적이며 보편적으로 적용가능하고, 서로 다른 국가 적 현실, 역량 및 개발수준을 고려하며, 국가의 정책과 우선순위를 존중한다. 세부목표는 
이렇듯 2030의제 및 SDGs 자체가 보편적 인권 정신에 입각한 다양한 인권협약 및 기준에 의거하여 수립되었다는 점에서 SDGs를 효과적으로 이행하고 달성하기 위해서는 우선적으로 SDGs의 각 목표(goals) 및 세부목표(targets)가 어떠한 인권 요소들과 연계되어 있는지에 대한 기본 이해가 필요하다. 가령 빈곤을 다루고 있는 SDG1이 UN경제사회문화권리위원회

(UN Committee on Economic Social and Cultural Rights, 이하 UNCESCR)에 의해 제시된 '빈곤(poverty)'의 다면적 개념에 기반하여 수립되었으며,6) 기아와 식량에 대해 다루고 있는 SDG2는 UNCESCR이 강조한 '충분한 음식을 섭취할 인간의 권리(rights to adequate food) 보장'에 기반하여 수립되었다7)는 그 배경을 이해할 경우 동 목표의 달성을 위한 이행 전략 및 사업 구상시 각 사업내용이 어떻게 인권 증진 및 보호에 기여할 수 있는지에 대한 종합적이고 통합된 이해 및 접근이 가능한 것이다. 이러한 SDGs와 인권간의 연계를 통해 SDGs 이행시 인권 의무(obligation)와 이행노력(commitments)이 효과적으로 이루어질 때, 갈수록 증대되는 불평등 위기를 해소하고 평등과 비차별을 실현하면서 '그 누구도 소외되지 않도록' 하는 방법으로 SDGs를 현실적으로 이행할 수 있을 것이다.

\section{2. 인권에 있어 SDGs가 갖는 중요성}

유엔헌장(UN Charter)에서는 서문(preemble)에서 UN 4대 기본 축(pillars)으로 '평화와 안보(peace and security)', '법치(rule of law)', '개발(development)'와 함께 '인권(human rights)'을 설정하고 있다. 이러한 4가지 축은 상호 연결되어 있으며, 상호 연계없이 특정 하나의 축만을 달성할 수는 없다고 강조하고 있으며, 이러한 4 가지 축은 UN이 행하는 모든 활동의 기본을 이루는 가치라 할 수 있다.

하지만 대양오염 및 기후변화 등과 같이 현 세대에서 주요하게 도래하고 있고, 인권 또한 이러한 이슈들과 긴밀하게 연결되어 고려되어야한다는 목소리가 높아지고 있음에도 불구하고

각 정부가 국제 수준에서의 지침에 의거하여 국가적 목표를 설정하면서도 국가적 상황을 염두에 둠에 따라 야심차며 국제적으로 정의된다. 각 정부는 또한 이 국제적인 세부목표를 어떤 식으로 국가 계획 과정, 정책 및 전략과 통합해야 하는 지 결정 할 것이다. 이는 지속가능발전과 다른 경제, 사회, 환경 분야에서 진행중인 과정과의 관련성을 인식하는 데 있어 중요하다(Targets are defined as aspirational and global, with each Government setting its own national targets guided by the global level of ambition but taking into account national circumstances. Each Government will also decide how these aspirational and global targets should be incorporated into national planning processes, policies and strategies. It is important to recognize the link between sustainable development and other relevant ongoing processes in the economic, social and environmental fields).

6) $\mathrm{E} / \mathrm{C} .12 / 2001 / 10(2001)$.

7) No. 12, E/C.12/1999/5 (1999). 
사실상 이러한 이슈들은 대부분 인권 시스템 밖에서 체결된 협정(convention)에 근거하여 다루어지고 있다. 이러한 점에서 2030의제는 이러한 기존의 인권시스템을 벗어나 있는 다양한 국제 인권 이슈들을 다루기 위한 하나의 '인권 실현 계획 또는 수단'으로 역할 가능하다. 따라서 SDGs는 발전권(right to development) 뿐만 아니라 경제권, 사회권, 문화권 등 모든 형태의 인권을 실현하기 위한 일종의 ‘행동계획(operational plan)' 이라고도 볼 수 있는 것이다(URG, 2017).

이처럼 SDGs을 인권실현을 위한 일련의 '이행수단' 으로 생각한다면, 반대로 '평등 및 비차별 (equality and non-discrimination), 참여 및 포용성(participation and inclusiveness), 그리고 책무성(accountability)'에 기반한 인권기본원칙(human rights principle)은 각국이 $\mathrm{SDGs}$ 이행시 고려해야할 주요 기준 및 방향을 제시하는 일련의 기준 틀로 역할한다고 할 수 있다. SDGs의 성공적 이행여부가 궁극적으로 '그 누구도 소외되지 않도록(leaving no one behind)' 하면서 실제 '가장 소외된 사람들에게 가장 최우선적으로 수혜가 가도록(reach the furthest behind first)' 얼마나 잘 이행되었는가에 달려있다는 점에서, 2030의제가 다양한 국가의 사정에 맞추어 실제 접목될 수 있도록 하는데 인권원칙이 일종의 프레임워크(framework)로 작동할 수 있는 것이다. 이러한 원칙을 준수함으로써 지속가능성을 개선시키고, 이를 통해 토착민, 장애인, 여성, 성소수자, 이주노동자, 아동 등과 같은 소외계층 및 취약계층들의 인권문제까지도 보다 포괄적으로 다룰 수가 있게 될 것이다.

이에 UN을 중심으로 한 국제사회에서는 전세계 인권 증진을 위해 다양한 노력을 해오고 있으며, 이는 모든 인권 활동의 근간이 되는 UN 세계인권선언(universal declaration of human rights)에 기반하여 인권기반 접근을 강조해오고 있다. 특히 UN의 '인권기반 접근에 대한 공통의 이해(UN Common Understanding on the Rights-Based Approach, 2003)'는 $\mathrm{UN}$ 기구들이 수행해 온 인권관련 협력을 체계화하여 개발관련 국가별 활동에 인권을 주류화 하는데 일조하였으며, UN은 2009년부터 인권 주류화 메커니즘을 설치하여 UN의 주요 정책과 사업에 인권적 관점을 반영하도록 촉진하고 있다(곽재성 외., 2017).

따라서 현재 전세계적으로 다양한 형태로 제기되고 있는 인권 이슈에 효과적으로 대응하기 위해서는 기존의 인권시스템이 갖는 대응력의 한계를 보완하여 보다 실질적인 이행전략으로서의 기제가 필요하고, 이러한 역할이 바로 SDGs가 효과적으로 기여할 수 있는 부분이라 할 수 있다. 이러한 인권과 SDGs간의 긴밀한 연관성에 대한 국제적 공감에 따라 2030 의제 수립 과정에서도 UN 인권협약기구(UN Treaty Bodies)는 SDGs가 세계인권선언(Universal Declaration of Human Rights)에 기반을 두어야한다는 점을 지속적으로 강조하였으며(UN, 2015a), UN 내 인권활동 증진 및 조정 역할을 담당하는 유엔인권최고대표사무소(Office of 
the United Nations High Commissioner for Human Rights, 이하 OHCHR) 또한 활동의 핵심 우선사항으로 SDGs가 국제인권기준(international human rights standards)과 일치 하는 방식으로 이행되도록 하는데 둠으로써 SDGs를 통한 인권실현이 제대로 이루어지도록 하는데 노력을 기울이고 있다.

제I 장

\section{제II장}

포

제표장

있다. 아울러 SDGs가 전세계적인 이행이 필요한 것과 마찬가지로 국제인권기준 또한 전세계적인 이행을 요구하는 분야라는 점에서 '인권의 보편성(universal human rights)'을 보장하기 위해서는 실제 두 메커니즘이 얼마나 부합하여 하나의 동일한 그림을 향해 나아가는 것이 중요하다고 할 수 있다. 즉 인권 메커니즘은 2030 의제 이행을 위한 기본원칙이자 이행 프레임워크로서 역할하는 동시에 SDGs는 인권 실현을 위한 구체적인 이행방안으로 작동함으로써 서로 시너지 효과를 발휘할 수 있는 것이다.

이러한 점에서 보았을 때, SDGs가 이러한 인권협약의 이행을 위한 구체적인 이행방안을 제시하지 못한다면, SDGs 또한 달성이 어려운 것이라 할 수 있다. 따라서 인권 및 지속가능개발 간 상호 연계된 체계를 마련하기 위해서는 책무성, 포용성, 참여, 일관성, 효율성 등을 종합적으로 고려한 통합적 접근이 요구된다. 통합적 접근의 이행을 위해서는 인권 및 2030의제 간 실체적인 연결성은 무엇인지, 그리고 인권 기준 및 매커니즘이 2030의제의 실현에 어떠한 기여를 할 수 있는지, 또한 2030의제가 인권 실현에 가장 효과적으로 기여할 수 있는지에 대한 논의 및 방안 마련이 이루어져야 한다.

아울러 이러한 SDGs와 인권간의 연계를 통한 하나의 통합적 이행방안이 마련될 경우, 첫째, SDGs 사업 이행 시 인권 기준 및 원칙에 의거함으로써 인권기반 사업운영의 정당성 및 체계성 제고, 둘째, 2030의제 이행 시 책무성(accountability) 보장, 셋째, 포용적이고 투명하며 참여적인 SDGs 이행 절차 촉구 가능, SDGs 이행 지침 및 모니터링을 제공할 수 있는 기존 자료 식별 등의 효과를 기대할 수 있을 것이다(Danish Institute for Human Rights, 2018).

이에 'SDGs 세부목표와 인권메커니즘간의 연결성(linkage)'에 대해 지속적으로 분석해온 덴마크인권연구소(Danish Institute for Human Rights)의 분석 결과에 따르면 SDGs 세부 
목표(targets)의 90\%이상이 주요 국제인권협약 및 기준을 반영하고 있음을 알 수 있다. 아울러 취약 계층 권리보유자(rights holders) 그룹별로 어떠한 SDGs 목표(goals) 및 세부목표(targets)들과 연계되는지를 연계성 또한 UN회원국 전체가 제출한 보편적정례검토(Universal Periodic Review, 이하 UPR) 보고서 결과를 바탕으로 도출한 바 있다. 따라서 다음 장에서는 동 연구소가 제공하고 있는 국제인권기준(instruments)와 취약계층별 SDGs 세부목표와의 연결성에 대해 분석 결과를 제시한 데이터베이스(database)를 활용하여 실제 SDGs와 인권 메커니즘이 얼마나 상호 부합 하여 하나의 동일한 그림을 향해 가고 있는지에 대해 살펴보고자 한다. 


\section{SDGs 세부목표별 국제인권기준 연계현황 분석}

\section{1. 분석 방법 및 대상}

본 장에서는 덴마크인권연구소(Danish Institute for Human Rights)에서 수행한 SDGs 169 개 세부목표(targets)에 대해 주요 79개 국제인권협약간의 연관성을 설명한 'The Human Rights Guide to the Sustainable Development Goals' 데이터베이스 (이하 인권기준 데이터베이스)를 주요 분석자료로 한다.8) 동 인권기준 데이터베이스는 목표(goals) 및 세부목표(targets)차원에서의 $\mathrm{SDGS}$ 와 UN회원국들의 국제 및 지역 인권, 노동, 환경 관련 기준(instruments)에 따른 이행의무 간에 얼마나 잘 연결되어있는지를 보여주고 있다.

이러한 분석에 앞서 사실상 국제 인권 기준(instruments)으로 제시되어 있는 원칙(principles) 및 권리(rights)의 개수가 상당히 많기 때문에 동 기준들을 적용할 수 있는 범위 또한 매우 넓어 사실상 SDGs 세부목표들 대부분에 연결된다고 할 수 있다. 따라서 동 데이터베이스에서는 사업 실무자들이 효과적으로 활용할 수 있도록 하는 데 초점을 맞추어 연결 작업을 시도하였다. 즉, 범이슈 또는 포괄적으로 적용가능한 권리 및 원칙 중에서도 SDGs 세부목표와 직접적인 연관성(direct linkage)을 가지는 것들을 중심으로 연결작업을 시도하였다. 이러한 연결 기준 하에 SDGs 세부목표 달성에 실제 기여할 수 있을거라 논의되는 국제기준들의 권리(rights), 조항 (provisions), 의무(obligations)들을 최대한 반영하여 문구상 직접적인 연결성을 가지는지를 판단하였다.

또한 이러한 연결과정에서 주의하여 이루어진 부분은 내용상 SDGs 세부목표의 거의 대부분과 매칭되는 '비차별(non-discrimination)'과 '발전권(right to development)'의 연계 방안이다. 먼저 비차별 원칙의 경우 모든 인권 기준(human rights instruments)에 적용되는 기본원칙 이다. 따라서 SDGs 각 세부목표와의 연계작업에서 가장 주요하게 고려되어야할 부분이기도 하다. 따라서 비차별 원칙은 SDGs 전반에 적용되어야 하지만, 동 데이터베이스에서는 비차별과 관련해서는 '불균등(disparities) 해소' 필요성이 세부목표상에 구체적으로 표현으로 명시되어 있는 경우에만 한정하여 연결작업을 진행하였다. 또한 발전권(right to development)9)의 경우

8) 덴마크인권연구소에서 소개하고 있는 'SDGs-인권규약데이터베이스'는 다음에서 확인가능하다: http://sdg.humanrights.dk/ (접속일: 2018.05.10.)

9) 동 데이터베이스에서는 발전권(right to development)의 경우 아프리카인권헌장(African Charter on Human and People's Rights, ACHPR) 22항(발전권)과 24항(환경권)에 의거한다. [22항] 모든 국가는 발전권을 영위할 권한을 가진다(States shall have the duty, individually or collectively, to ensure the exercise of the right 
에도 거의 모든 SDGs 세부목표와 연관된다. 따라서 이러한 광범위한 적용가능성 및 동 데이터 베이스 활용 효율성을 위해 아래의 기준에 따라 연결대상 인권기준의 범위를 한정하여 연계작업을 실시하였다.

- 세부목표상의 표현 중 개발권(right to development) 또는/그리고 회원국들이 개발권 이행 의무 강화의 필요성을 언급하고 있는 경우,

- 세부목표상의 표현 중 개발에 적합한 환경 조성(general satisfactory environment favourable to their development)을 의도한 구체적인 정책 또는 기타 조치를 언급한 경우 또는 개발에 우호적인 환경 상태 구축과 관련한 내용을 언급한 경우,

- 세부목표상의 표현 중 개발에 우호적인 환경조성을 위한 방안 및 조건들을 언급한 경우.

따라서 상기와 같은 분석 기준 및 방법에 따라 동 인권규약 데이터베이스에서는 주요 인권 기준, 국제 노동기준, 인권적 요소를 포함하고 있는 주요 환경 협정 등을 종합적으로 고려하여 총 79 개 인권기준(human rights instruments)들을 분석대상으로 선정하였다. 이러한 선정기준에 따라 동 데이터베이스에서는 79 개 인권관련 기준(instruments)이 활용되었다. 동 기준들을 세 가지 분류 카테고리별로 적용범위 및 형태에 따라 정리하면 아래 <표 $1>$ 과 같다. 동 표에서 알 수 있는 바와 같이 단순히 2030 의제가 기반하고 있는 유엔인권선언(UN Universal Declaration of Human Rights) 및 9대 인권협약(Human Rights treaties) 만을 고려하는 것이 아니라, 권고안, 의정서, 기타 선언 및 협약 등을 포괄적으로 고려하고 있다. 또한 특이한 점은 SDGs의 이행주체가 단순히 개도국에 국한되지 않고 선진국을 비롯한 개도국, 기업 등 그 범위가 매우 광범위해졌다는 점에서 유럽, 아프리카, 아메리카 등 주요 권역에서 적용되고 있는 인권관련 협약 및 의정서 또한 포함하여 다함께 고려하고 있다는 점이다. 아울러 국제 기준 뿐만 아니라 지역 차원에서의 기준까지 모두 고려해야할 필요성은 2030의제에서도 강조되고 있는데, 21조에서의 ‘국제(international)' 차원 뿐만 아니라 지역(regional) 차원에서의 기준들 또한 포괄적으로 포함해야 한다‘는 부분과’ 25조에서’이러한 국제 및 지역 차원에서의 목표 및 기준들을 국가 정책 및 이행 차원에서도 효과적으로 반영될 수 있도록 해야한다'는 부분이 그러하다.

to development), [24항] (All peoples shall have the right to a general satisfactory environment favourable to their development). 
〈표 1〉 분석 대상

\begin{tabular}{|c|c|c|}
\hline 분류 & 적용범위 & 형태 \\
\hline \multirow{2}{*}{$\begin{array}{l}\text { 1. 주요 인권 기준 } \\
\text { (human rights instruments) } \\
\text { (총 32개) }\end{array}$} & $\begin{array}{c}\text { 국제 기준 } \\
\text { (international instruments) }\end{array}$ & 선언, 협약, 의정서, 권고안 \\
\hline & $\begin{array}{c}\text { 지역 기준 } \\
\text { (regional instruments) } \\
\text { 유럽, 아프리카, 아메리카 지역 }\end{array}$ & 헌정, 협약, 의정서 \\
\hline $\begin{array}{l}\text { 2. 노동기준 } \\
\text { (international labour standards) } \\
\text { (37개) }\end{array}$ & 국제 & 협약, 의정서, 권고안 \\
\hline $\begin{array}{l}\text { 3. 인권 관련 주요 환경 규약 } \\
\text { (key environmental instruments - } \\
\text { some of which have human rights } \\
\text { dimensions) (10개) }\end{array}$ & 국제 & 협약, 의정서 \\
\hline
\end{tabular}

제 I 장

\section{제II장}

출처: SDGs-인권기준데이터베이스(sdg.humanrhights.dk/) (접속일: 2018.05.10.) 바탕으로 저자 재구성

하단의 <표 2>는 79 개 인권기준 구성에 대한 이해를 돕기 위해 3가지 카테고리별로 세부주제를 정리한 표이다. 세부주제 선정 기준은 각 기준(instruments)명에서 직접 제시되어 있는 용어들로 선정하였다. 가령 아동의 권리에 관한 협약(Convention on the Rights of the Child, $\mathrm{CRC)}$ 의 경우 '아동' 으로, UN원주민권리선언(United Nations Declaration on the Rights of Indigenous Peoples, UNDRIP)의 경우 ‘원주민’으로 표기하였다.

\section{〈표 2〉 79개 인권기준 카테고리별 세부주제}

\begin{tabular}{l|l}
\hline \multicolumn{1}{c|}{ 분류 } & \multicolumn{1}{c}{ 세부주제 } \\
$\begin{array}{l}\text { 1. 주요 인권 기준 } \\
\text { (총 32개) }\end{array}$ & $\begin{array}{l}\text { 기본권, 정치권, 사회권, 인권과 의무, 인종차별, 아동, 여성, 장애, 이주 } \\
\text { 노동자, 원주민, 소수민족, 고문방지, 실종방지, 기업인권, 반부패, 조직범죄, } \\
\text { 집단살해죄, 담배규제 등 }\end{array}$ \\
\hline $\begin{array}{l}\text { 2. 노동기준 } \\
\text { (37개) }\end{array}$ & $\begin{array}{l}\text { 강제근로, 근로감독, 취업이주, 결사 및 단결권, 노동조항, 임금보호, 단체 } \\
\text { 교섭권, 동등보수, 노동최저기준, 노동최저연령, 최저임금, 균등대우(고용 } \\
\text { 차별), 고용정책, 인적자원, 산업안전, 가족부양근로자, 사회보장권, 장애인 } \\
\text { 고용, 삼자협의, 소수자(토착민 및 부족민, 여성, 아동) 노동권, 근로조건, } \\
\text { 직업소개소, 해사노동, 어선근로, 중소기업 등 }\end{array}$ \\
\hline $\begin{array}{l}\text { 3. 인권 관련 } \\
\text { 주요 환경 규약 (10개) }\end{array}$ & \begin{tabular}{l} 
환경, 생물다양성, 기후변화 등 \\
\hline
\end{tabular}
\end{tabular}

출처: 저자 작성

동 표에서 알 수 있는 바와 같이, 인권관련 기준은 총 32개, 노동 관련 세계노동기구(International Labour Organisation, 이하 ILO) 기준은 37개, 환경관련 협약은 10 개로 구성되어 있음을 알 수 있다. 특히 2030 의제 또한 이러한 9 개 인권 협약에 근거하고 있으며, SDGs의 광범위한 
17 개 목표에 부합하는 인권 통합방안을 마련하기 위해서는 인권 내에서의 사회권, 자유권, 여성 및 아동, 장애인 권리 뿐만 아니라 노동권 및 환경분야에서 거론되는 인권 분야까지 포괄적으로 고려되어야 한다는 점에서 상기와 같이 종합적인 부문에서의 인권 관련 기준을 고려하는 것은 적절하다고 할 수 있다.

아래 <표 3>은 상기의 이러한 분류기준에 따라 분석대상으로 선정된 총 79 개 인권 기준 (instruments)에 대한 총괄표이다. 


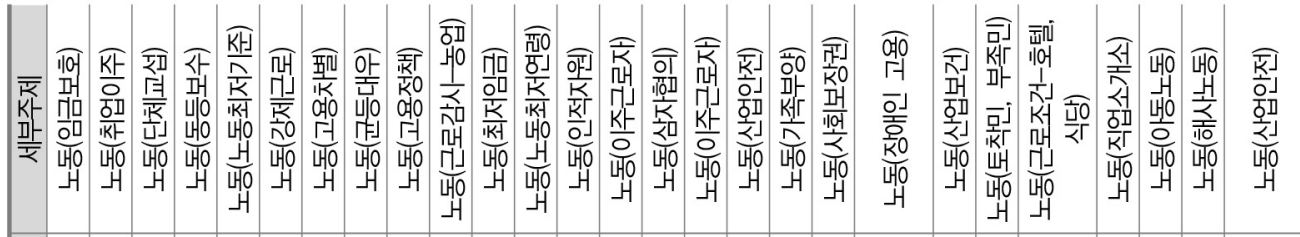
輻

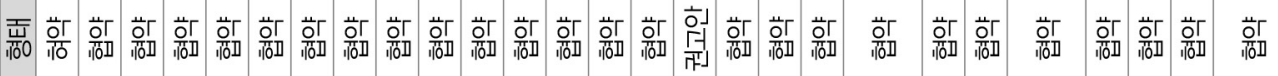

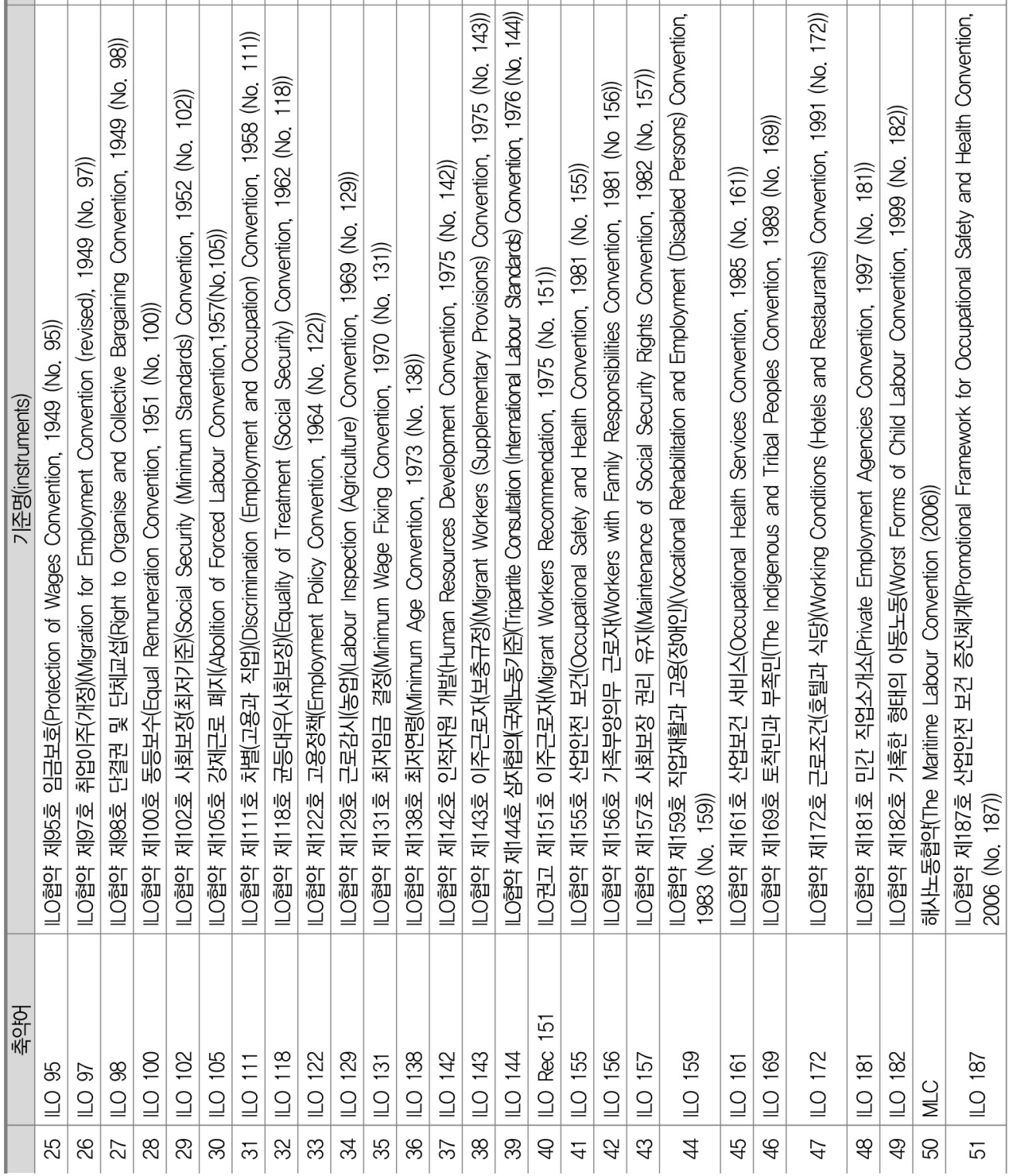




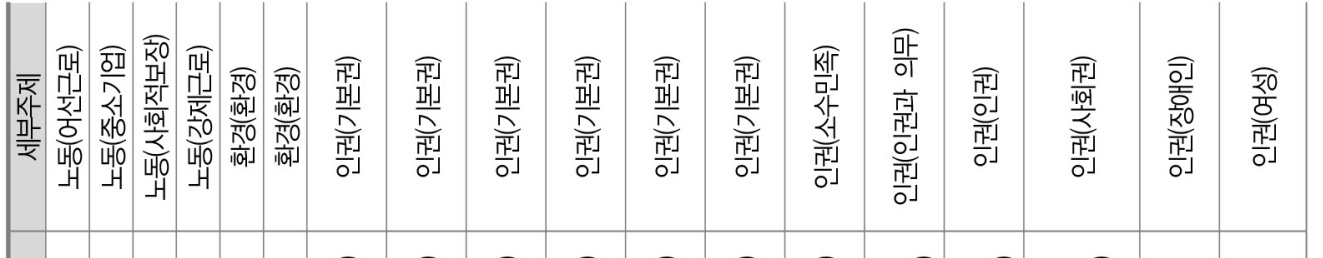

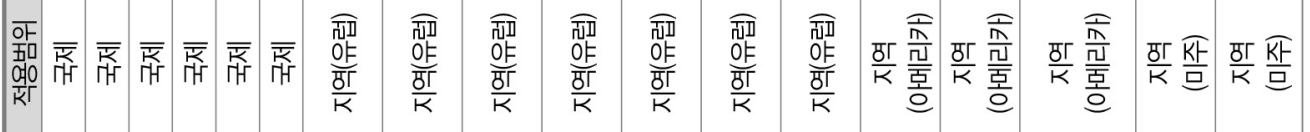

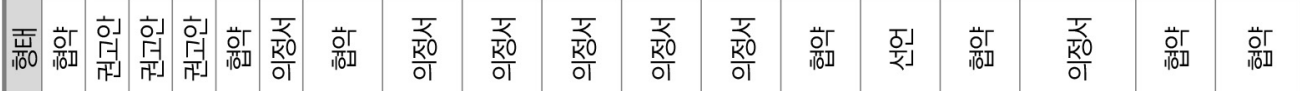

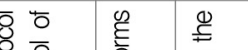

\begin{tabular}{|c|c|c|c|c|c|c|}
\hline 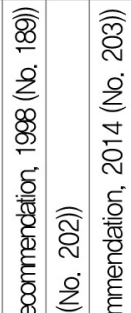 & 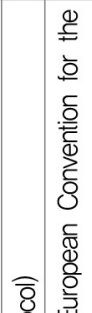 & 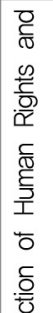 & 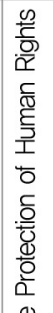 & 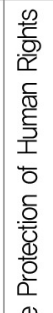 & 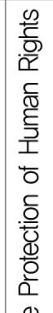 & 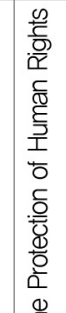 \\
\hline
\end{tabular}

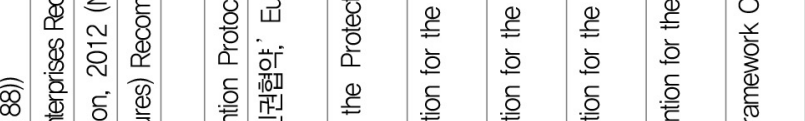

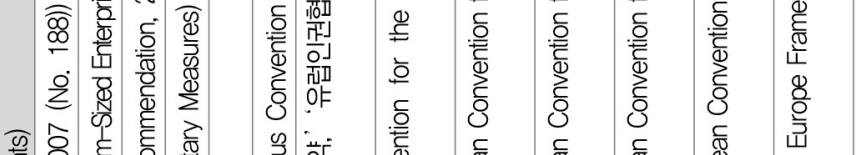

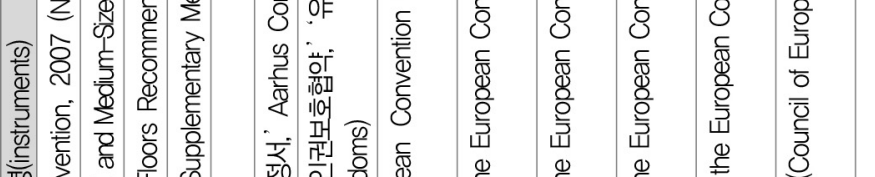

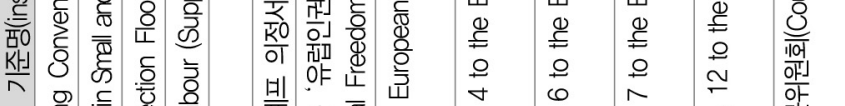

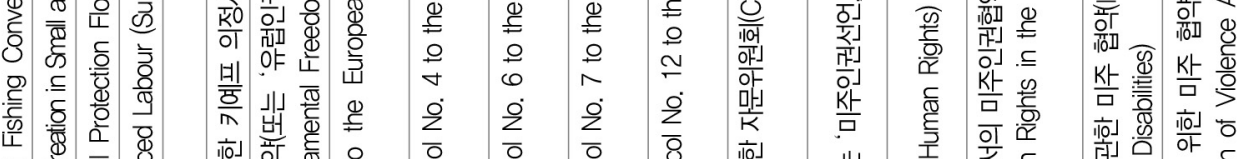

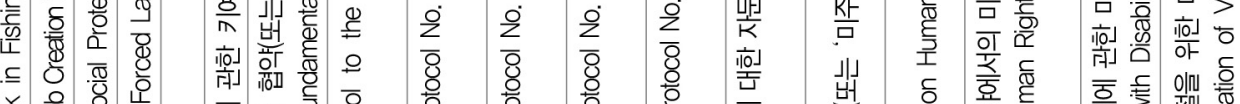

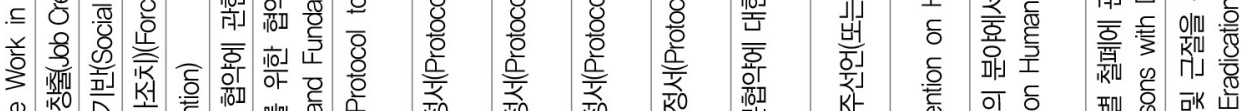

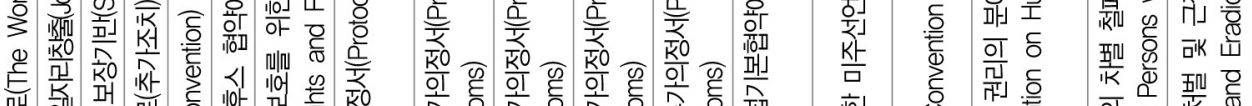

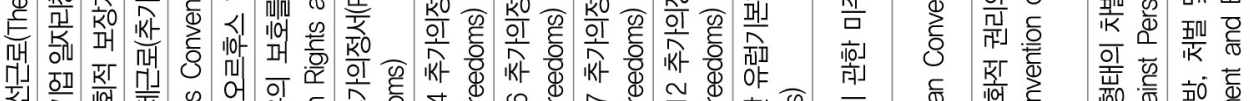

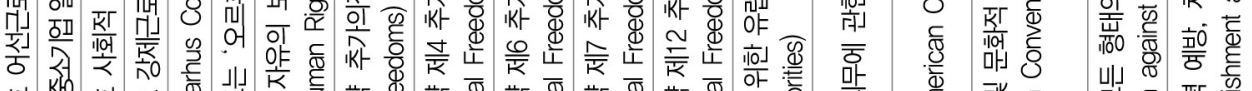

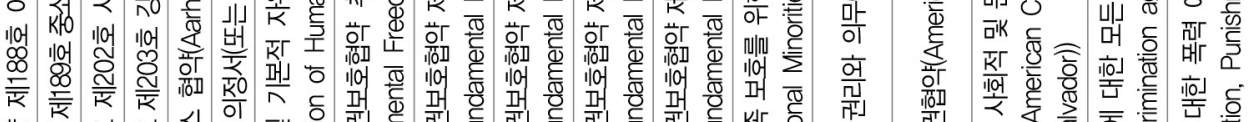

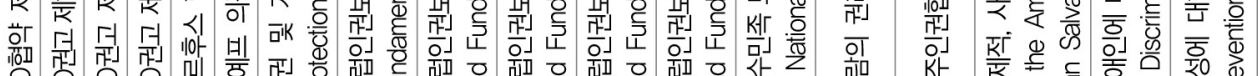

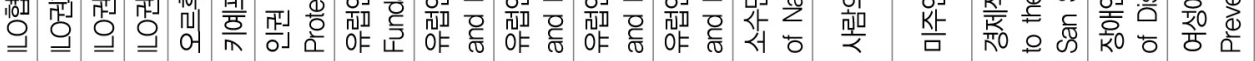

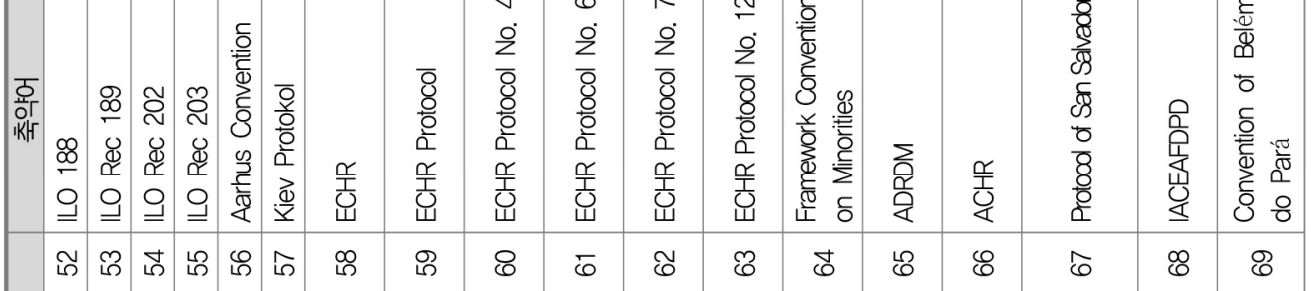

제 I 장

제II 장

섹

터

포

커

제표장 


\begin{tabular}{|c|c|c|c|c|c|c|c|c|c|c|c|}
\hline & 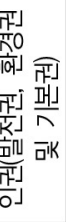 & 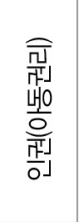 & 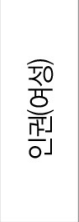 & 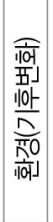 & 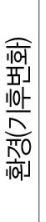 & 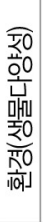 & 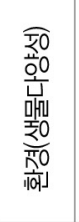 & 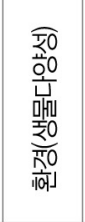 & 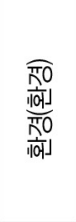 & 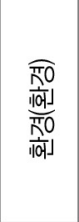 & \\
\hline 㓤 & 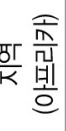 & 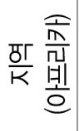 & $\frac{\text { 胥 }}{\mathrm{K}}$ & $\underset{\text { 疍 }}{\bar{r}}$ & $\begin{array}{l}\text { 蛋 } \\
\text { | }\end{array}$ & $\sqrt{\sqrt{⿱ 乛 龰}}$ & 蛋 & $\underset{\text { 疍 }}{\text { 严 }}$ & $\underset{\text { 蛋 }}{\text {. }}$ & 疍 & \\
\hline$\frac{1}{100}$ & 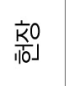 & 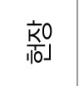 & $\frac{\bar{\Sigma}}{\frac{\bar{K} 0}{O O}}$ & $\mid \begin{array}{l}\frac{1}{0} \\
\text { or } \\
\text { ibl }\end{array}$ & \begin{tabular}{|l|l} 
\\
\\
or
\end{tabular} & 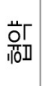 & 落 & 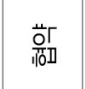 & 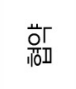 & 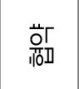 & \\
\hline 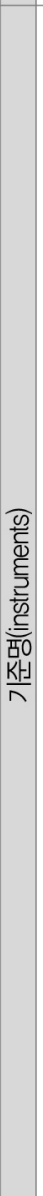 & 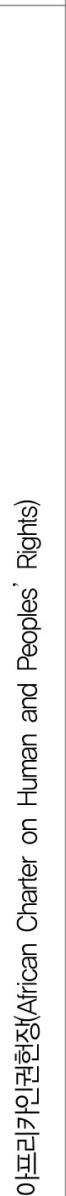 & 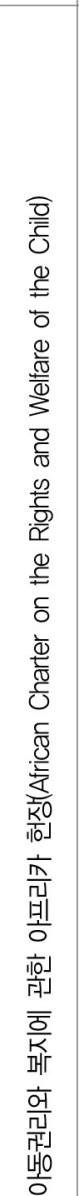 & 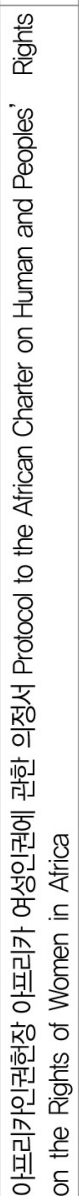 & 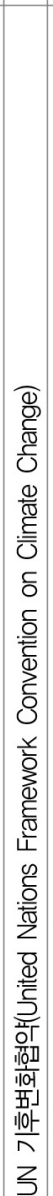 & 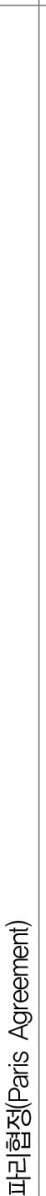 & 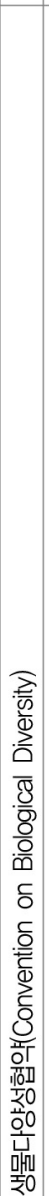 & 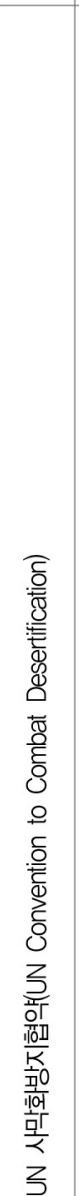 & 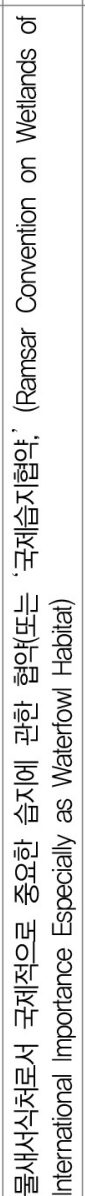 & 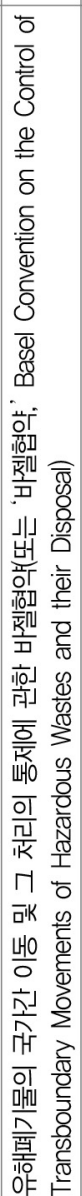 & 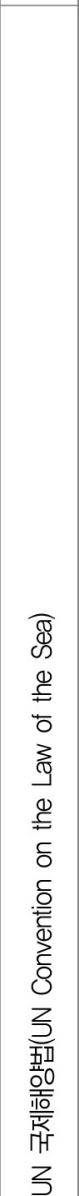 & 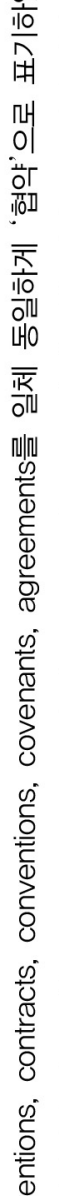 \\
\hline 용 & $\frac{\frac{r}{0}}{\frac{1}{0}}$ & 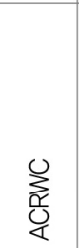 & 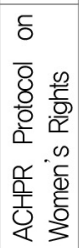 & 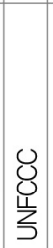 & 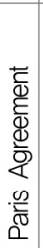 & & 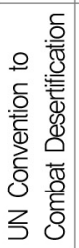 & 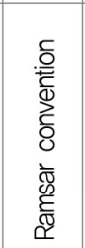 & 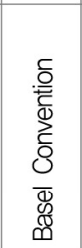 & 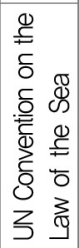 & 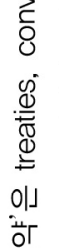 \\
\hline & $R$ & $\Sigma$ & $\mathbb{N}$ & $\mathfrak{N}$ & $\pi$ & | & $\stackrel{Q}{\curvearrowright}$ & $\kappa$ & $\stackrel{\infty}{\stackrel{\infty}{~}}$ & R & \\
\hline
\end{tabular}




\section{2. 분석 결과}

1) SDGs 목표별 국제인권기준 연계 현황

〈표 4〉SDGs 목표별 79 개 국제인권기준 반영 현황

\begin{tabular}{|c|c|c|c|c|}
\hline $\mathrm{SDG}$ 목표 & $\begin{array}{c}\text { 인권 반영 } \\
\text { 세부목표 개수 }\end{array}$ & $\begin{array}{c}\text { 인권 미반영 } \\
\text { 세부목표 개수 }\end{array}$ & $\begin{array}{l}\text { 총 세부목표 } \\
\text { 개수 }\end{array}$ & $\begin{array}{c}\text { 인권 미반영 } \\
\text { 세부목표 }\end{array}$ \\
\hline \multirow{2}{*}{1 (빈곤) } & 7 & 0 & 7 & \\
\hline & $(4.1 \%)$ & $(0.0 \%)$ & $(4.1 \%)$ & \\
\hline \multirow{2}{*}{2 (기아) } & 8 & 0 & 8 & \\
\hline & $(4.7 \%)$ & $(0.0 \%)$ & $(4.7 \%)$ & \\
\hline \multirow{2}{*}{3 (보건) } & 13 & 0 & 13 & \\
\hline & $(7.7 \%)$ & $(0.0 \%)$ & $(7.7 \%)$ & \\
\hline \multirow{2}{*}{4 (교육) } & 10 & 0 & 10 & \\
\hline & (5.9\%) & $(0.0 \%)$ & (5.9\%) & \\
\hline \multirow{2}{*}{5 (성평등) } & 9 & $0(0 \%)$ & 9 & \\
\hline & $(5.3 \%)$ & $(0.0 \%)$ & $(5.3 \%)$ & \\
\hline \multirow[b]{2}{*}{6 (물) } & 8 & 0 & 8 & \\
\hline & $(4.7 \%)$ & $(0.0 \%)$ & $(4.7 \%)$ & \\
\hline \multirow{2}{*}{7 (에너지) } & 5 & 0 & 5 & \\
\hline & $(3.0 \%)$ & $(0.0 \%)$ & $(3.0 \%)$ & \\
\hline \multirow{2}{*}{8 (일자리) } & 11 & 1 & 12 & 8.1 \\
\hline & (6.5\%) & $(0.6 \%)$ & $(7.1 \%)$ & \\
\hline \multirow{2}{*}{9 (산업) } & 8 & 0 & 8 & \\
\hline & $(4.7 \%)$ & $(0.0 \%)$ & $(4.7 \%)$ & \\
\hline \multirow{2}{*}{10 (불평등) } & 9 & 1 & 10 & 10.5 \\
\hline & $(5.3 \%)$ & $(0.6 \%)$ & $(5.9 \%)$ & \\
\hline \multirow{2}{*}{11 (도시) } & 10 & 0 & 10 & \\
\hline & (5.9\%) & $(0.0 \%)$ & (5.9\%) & \\
\hline \multirow{2}{*}{12 (생산과 소비) } & 11 & 0 & 11 & \\
\hline & $(6.5 \%)$ & $(0.0 \%)$ & $(6.5 \%)$ & \\
\hline \multirow{2}{*}{13 (기후변화) } & 5 & 0 & 5 & \\
\hline & $(3.0 \%)$ & $(0.0 \%)$ & $(3.0 \%)$ & \\
\hline \multirow{2}{*}{14 (해양생태계) } & 10 & 0 & 10 & \\
\hline & (5.9\%) & $(0.0 \%)$ & (5.9\%) & \\
\hline \multirow{2}{*}{15 (육상생태계) } & 12 & 0 & 12 & \\
\hline & $(7.1 \%)$ & $(0.0 \%)$ & $(7.1 \%)$ & \\
\hline \multirow{2}{*}{16 (평화거버넌스) } & 12 & 0 & 12 & \\
\hline & $(7.1 \%)$ & $(0.0 \%)$ & $(7.1 \%)$ & \\
\hline \multirow{2}{*}{17 (파트너십) } & 19 & 0 & 19 & \\
\hline & $(11.2 \%)$ & $(0.0 \%)$ & $(11.2 \%)$ & \\
\hline \multirow{2}{*}{ 합계 } & 167 & 2 & 169 & \\
\hline & (98.8\%) & $(1.2 \%)$ & $(100.0 \%)$ & \\
\hline
\end{tabular}

출처: SDGs-인권기준데이터베이스(http://sdg.humanrights.dk/) 바탕으로 저자 작성 (접속일: 2018.05.10.) 
상기 <표 4>는 SDGs-인권기준 연계 데이터베이스를 활용하여, SDGs 169 개 세부목표들 중 국제인권기준이 1 개라도 반영된 세부목표의 개수를 SDGs 17 개 목표 차원에서 살펴본 표이다. 동 표에서 알 수 있는 바와 같이, SDGs 각 세부목표들을 대상으로 국제인권기준 반영정도를 살펴보면 총 169 개 중 2 개10)를 제외한 175 개 세부목표가 인권기준과 연계되어 있음을 알 수 있다. 이는 앞서 말한 바와 같이 SDGs 세부목표 대다수가 인권과 긴밀히 연결되어 있음을 다시 한번 보여주는 결과이다.

또한 전체적으로 동 데이터베이스 상에서 SDGs의 세부목표와 인권기준간의 연결 구조를 보면 다음과 같다. 먼저, 156 개 세부지표는 국제인권기준(international human rights instruments)과 노동기준(labour standards)와 연결되어 있으며, 132 개는 미주간 지역인권기준(inter-American regional human rights instruments)과, 135 개 세부목표는 아프리카 지역 인권기준과, 68 개 세부목표는 유럽지역 인권기준과 연결되어 있다. 또한 79개 세부목표는 국제 환경 및 기후변화 기준(international environmental and climate change instruments)과 연결되어 있다.

〈그림 1〉SDGs 목표별 79개 국제인권기준 연계 비중

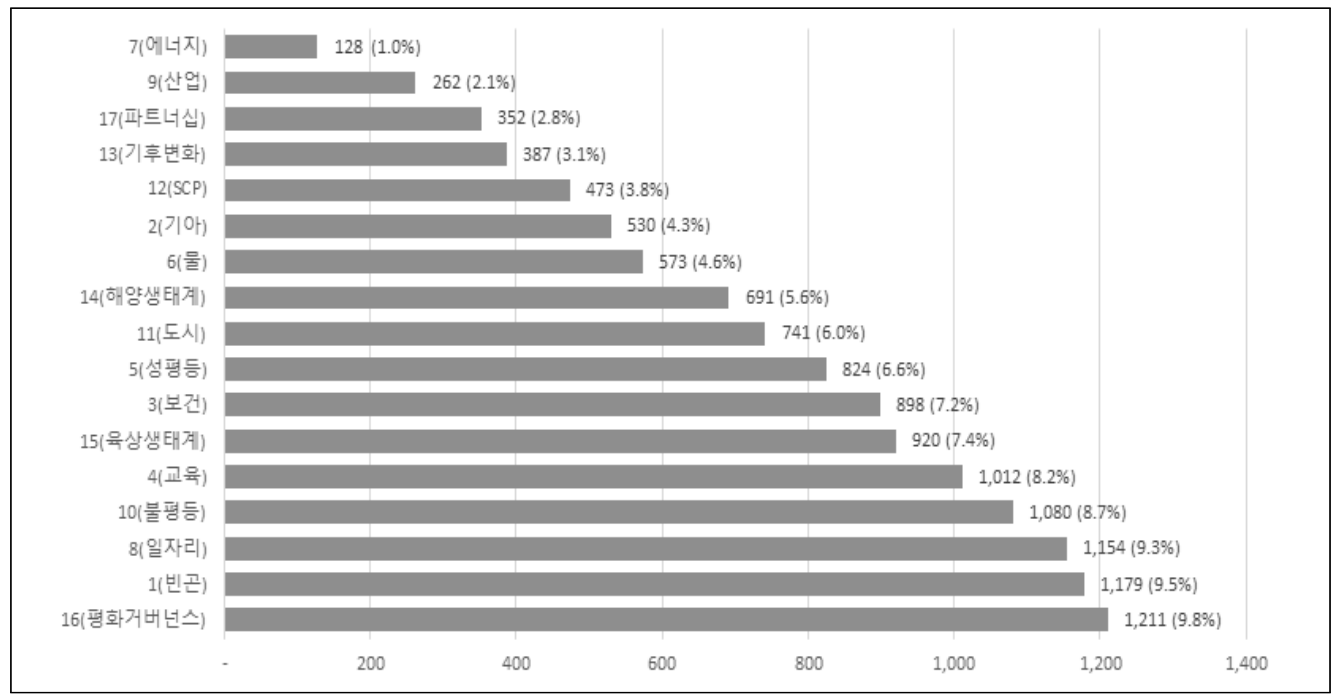

출처: SDGs-인권기준데이터베이스(http://sdg.humanrights.dk/) 바탕으로 저자 작성 (접속일: 2018.05.10.)

10) 인권기준이 반영되지 않은 2 개 세부목표(targets)는 다음과 같다. (1) [8.1] 국가별 상황에 따라 1 인당 경제성장을 지속하고, 특히 최빈개도국에서는 최소 연 7\%의 국내총생산 성장을 지속한다(Sustain per capita economic growth in accordance with national circumstances and, in particular, at least 7 per cent gross domestic product growth per annum in the least developed countries). (2) [10.5] 전세계 금융시장과 기구들의 규제와 모니터링을 개선하고 이와 같은 규제의 이행을 강화한다(Improve the regulation and monitoring of global financial markets and institutions and strengthen the implementation of such regulations). 
아울러 79 개의 인권 기준(instruments)의 각 조항(articles)을 펼쳐놓고 보면 12,415 개 인권 기준 조항이 SDGs 세부목표와 연계될 수 있다. 이렇게 각 기준 조항 수준에서 세밀하게 SDGs 세부목표와 어떠한 연계성을 갖는지 살펴보면 상기 <그림 1 >과 같다. 동 그림에 서 보이는 바와 같이 SDG16(평화 및 거버넌스)가 세부목표 차원에서 살펴볼 때 인권기준 조항 1,211 개와 매핑됨에 따라 가장 높은 연계성을 가지며, 그 뒤로 SDG1(빈곤), SDG8(일자리), SDG10(불평등), $\mathrm{SDG} 4$ (교육) 순으로 높은 매핑율을 보인다.

이러한 매핑결과를 실제 전략 수립 및 사업 기획 단계에서 활용하기 위해서는 각 세부목표별로 어떠한 인권기준들과 연결되며, 각 기준들에서도 어떠한 조항(article)에 근거하여 있는지에 대한 내용(description) 확인이 이루어져야 한다. 동 분석에서는 지면의 한계상 각 세부목표별로 어떠한 조항(article)들과 연결되는지까지는 소개하지 못하였으나, [붙임1]에서 각 SDGs 세부목 표별로 연결되어 있는 각 인권기준들의 조항 개수를 종합정리하여 표기하였다. 각 연결된 상세 조항들의 내용은 동 데이터베이스에 접속하여 확인가능하다.11)

가령 농촌개발 사업을 기획시 사업의 세부목표로 SDG2.3을 반영하여 하단의 <표 5>에서와 같이 '농경생산이나 소작농의 소득을 2 배로 증대' 한다는 세부목표를 사업 목표 중의 하나로 설정한다고 할 경우, 동 목표와 관련한 다양한 인권기준들의 내용을 고려하여 인권 요소를 사업 활동의 내용 및 방향 설정, 측정 내용 구성 과정 등에 접목시킬 수 있다 즉 SDG2 자체가 '적당한 음식과 적당한 생활수준을 영위하도록 한다'는 식량권과 관련하여 ICESCR에 의해 수립된 목표라는 점에서 동 세부목표의 이행 자체가 ICESCR 인권 규약의 이행에 또한 기여한다는 점에서 동 사업이 인권요소를 고려한 사업운영의 보다 명확한 명분 및 근거를 제시할 수 있는 것이다. 아울러 농경사업을 운영하는 과정에서 자칫 간과되기 쉬운 취약계층, 즉 여성, 토착민, 소작농 등과 같은 취약계층의 권리가 어떠한 측면에서 특히 보호되어야하는지, 그리고 관련 노동 및 환경 인권은 어떠한 것들을 점검해야하는지 에 대한 고려 기준 중의 하나로 활용할 수 있을 것이다.

11) 동 데이터베이스(http://sdg.humanrights.dk/en)에서 각 SDGs 목표 및 세부목표별로 연결되는 인권관련 기준 (instruments) 및 관련 조항(article)에 대해 구체적으로 소개하고 있다. 
〈표 5〉SDGs 세부 목표와 인권 연계 이해 (예시)

\begin{tabular}{|c|c|}
\hline G2 & 틱식, 식량안보와 영양 개선 달성 및 지 \\
\hline SDG2.3 & $\begin{array}{l}\text { 30년까지 토지 및 기타 생산 자원과 투입요소, 지식, 금융서비스, 시장 } \\
\text { 추롸 비농업부문 고용 기회에 대한 안전하고 평등한 접근을 통하여 } \\
\text { 난자, 특히 여성, 토착민, 가족농, 목축민 및 어민의 농업생산성과 소득 }\end{array}$ \\
\hline & $\begin{array}{c}\text { 조항/설명 } \\
\text { (article/description) }\end{array}$ \\
\hline $\begin{array}{l}\text { 경제적- } \\
\text { 문화적 구 } \\
\text { 국제규으 }\end{array}$ & $\begin{array}{l}\text { 11조2항 이 규약의 당사국은 기아로부터의 해방이라는 모든 사람의 기본적인 권리를 } \\
\text { 인정하고, 개별적으로 또는 국제협력을 통하여 아래 사항을 위하여 구체적 계획을 } \\
\text { 포함하는 필요한 조치를 취한다. } \\
\text { (a) 과학·기술 지식을 충분히 활용하고, 영양에 관한 원칙에 대한 지식을 보급하고, } \\
\text { 천연자원을 가장 효율적으로 개발하고 이용할 수 있도록 농지제도를 발전시키거나 } \\
\text { 개혁함으로써 식량의 생산, 보존 및 분배의 방법을 개선할 것. }\end{array}$ \\
\hline $\begin{array}{l}\text { UN 원주민 권리 } \\
\text { 선언 } \\
\text { (UNDRIP) }\end{array}$ & $\begin{array}{l}\text { 26조1항 원주민은 본인들이 전통적으로 소유 또는 차지해왔거나, 그렇지 않을 } \\
\text { 경우 실질적 의미에서 사용 및 점유해온 토지, 영토, 자원에 대한 권한을 가진다. } \\
\text { 26조2항 원주민들은 전통적으로 오랜 기간 동안 소유 또는 획득, 이용해온 토지 } \\
\text { 및 영토, 자원 등에 대해 소유, 이용, 개발, 통제할 권한을 가진다. }\end{array}$ \\
\hline $\begin{array}{l}\text { 유엔사막화 } \\
\text { 방지협약 } \\
\text { (UN Convention to } \\
\text { Combat } \\
\text { Desertification) }\end{array}$ & $\begin{array}{l}\text { 4조(공통적의무-당사국의무) (c) 빈곤퇴치전략을 사막화방지 및 한발피해완화를 } \\
\text { 위한 노력에 통합시켜야 한다. } \\
5 \text { 조(피해당사국의 의무) (c) 사막화의 기저에 있는 원인에 대처하여, 사막화 과정을 } \\
\text { 조장하는 사회경제적 요인에 특별한 주의를 기울일 것 } \\
10 \text { 조(국가실천계회) } 3 \text { 항. 국가실천계획은 한발피해에 대비하고 피해를 완화하기 } \\
\quad \text { 위하여 특히 다음의 조치의 일부 또는 전부를 포함할 수 있다. } \\
\text { (d) 한발빈발지역에서 소득원이 될 수 있는 대체생계수단 확보계획의 수립 } \\
\text { (e) 곡물 및 가축을 위한 지속가능한 관개계획의 개발 } \\
10 \text { 조(국가실천계획)4항. 국가실천계획은 각 피해당사국의 특별한 상황과 필요성을 } \\
\text { 고려하여, 적절한 경우, 피해지역의 사막화방지 및 한발피해완화와 그 주민에 } \\
\text { 관련된 조치로서 다음의 우선적 분야의 일부나 전부를 포함한다. } \\
\text { - 빈곤퇴치와 식량확보를 목표로 하는 계획의 강화를 위한 대체생계수단의 } \\
\text { 장려 및 국가경제환경의 개선 } \\
\text { - 인구구성의 변화 } \\
\text { - 천연자원의 지속가능한 관리 } \\
\text { - 지속가능한 농업행위 } \\
\text { - 다양한 에너지 공급원의 개발 및 효율적 사용 } \\
\text { - 법적제도적 장치 } \\
\text { - 수문학적 및 기상학적 서비스를 포함한 평가와 체계적 관찰을 위한 능력의 } \\
\text { 강화 } \\
\text { - 능력형성ㄱㄱㅇ육 및 대중의식제고 }\end{array}$ \\
\hline
\end{tabular}

출처: SDGs-인권기준데이터베이스(http://sdg.humanrights.dk/en/targets2?goal[]=71\&target=2.3) (접속일: 2018.05.10.) 


\section{SDGs 세부목표별 취약그룹 연계 현황 분석}

\section{1. 분석 방법 및 대상}

덴마크인권연구소는 'SDGs-인권기준 데이터베이스'와 함께 'SDGs-UPR 데이터베이스 (UPR-SDG Data Explorer, 이하 UPR 데이터베이스)'12) 또한 구축함으로써 UPR 수검을 받는 UN회원국 전체에 대해 제시된 UPR 권고사항(recommendation)들이 SDGs 목표(goals) 및 세부목표(targets)와 어떻게 연계되는지 보여주고 있다. 아울러 9개의 권리보유자(rightsholders)별 취약계층 그룹을 나누어 SDGs 각 목표 및 세부목표가 취약계층별로 연결하는 작업도 시도하였다.

본래 SDGs가 인권메커니즘과 얼마나 유기적으로 연결되어 있는지를 살펴보는 동시에 이를 통해 SDGs를 보다 인권기반 방식으로 효과적으로 이행하도록 하기 위해서는 UN 회원국들에게 제시된 UPR 권고사항의 내용이 무엇이고 이것이 SDGs 각 목표 및 세부목표와는 어떻게 연계되는지 종합적으로 살펴보아야 한다. 권고사항 자체가 해당 국가의 인권 상황의 개선이 필요한 현 지점이 무엇인지를 나타내는 부분이라는 점에서 권고사항에 대한 분석은 앞으로 보편적 인권을 실현하기 위해 우리가 어떤 부분에 보다 주력해야할지를 판단할 수 있는 기준이 된다고 할 수 있기 때문이다. 하지만 이러한 권고사항은 UPR 체계 도입이후 총 55,000개 이상이 UN 회원국들에게 제시되어 왔다는 점에서 그 방대한 양으로 인해 UPR 권고사항 이행 현황에 대한 체계적인 관리가 사실상 힘든 실정이다. 아울러 2030의제의 채택에 따라 UPR 권고사항들을 SDGs 목표 및 세부목표와 연결시키려는 노력이 지속되고 있으나, 방대한 양의 $\mathrm{SDGs}$ 세부목표들을 UPR 권고사항에 맞추어 하나씩 분류하는 것 또한 현실적으로 어렵다. 따라서 이러한 권고사항을 보다 효과적으로 이행하고 관리하기 위해서는 동 권고사항에 대해 ‘주제별(thematic)'로 범주화하여 분류하고 이를 SDGs 목표 및 세부목표와 연계해보는 시도가 필요하다.

이에 동 데이터베이스에서는 UPR 체제가 시작된 이래 현재까지 총 2 번 진행됨에 따라 UPR 첫 번째(2008-11년) 및 두 번째(2012-16년) 주기의 권고사항 전체를 분석대상으로 하고 있다. 이에 UPR Info가 제공하는 UPR권고사항 데이터베이스(database of recommendations)13)와

12) 덴마크인권연구소의 'SDGs-UPR 데이터베이스'는 다음에서 확인가능하다. http://upr.humanrights.dk/ (접속일: 2018.05.10.)

13) UPR 권고사항 일체에 대해 제공하는 데이터베이스는 다음과 같다. https://www.upr-info.org/database/ (접속일: 2018.05.10.) 
$\mathrm{OHCHR}$ 가 실시하는 보편적인권지수(universal human rights index)14) 결과를 종합하여 UPR 데이터베이스를 구축하였다.

아울러 동 데이터베이스는 $\mathrm{OHCHR}$ 의 보편적인권지수에 포함된 그룹분류기준을 일부 수정 하여 취약계층별 그룹 범주를 하단 <상자 1 >과 같이 아동(children), 인권보호자(human rights defenders), 토착민(Indigenous peoples), 국내실향민(Internally displaced persons, IDPs), 소수집단(members of minorities), 이민자(migrants), 장애인(persons with disabilities), 피난민(refugees and asylum-seekers), 여성과 소녀(women and girls) 등 총 9개로 분류 하였다.

\section{〈상자 1〉 분석대상 취약계층별 구분}

- 아동(children)

- 인권보호자(human rights defenders)

- 토착민(Indigenous peoples)

- 국내실향민(Internally displaced persons, IDPs)

- 소수집단(members of minorities)

- 이민자(migrants)

- 장애인(persons with disabilities)

- 피난민(refugees and asylum-seekers)

- 여성과 소녀(women and girls)

출처: SDGs-UPR데이터베이스(upr.humanrights.dk/groups) 참조 (접속일: 2018.05.10.)

이에 동 UPR 데이터베이스에서는 상기의 9개 취약계층 그룹별로 UPR 총 권고수가 얼마이고, 이 중에서 수검 회원국 내에서 이행 승낙(accept)을 받은 비율은 얼마인지에 대한 매핑 결과와 함께 SDGs와는 얼마나 연결되는지에 대한 결과까지 종합적으로 보여주고 있다. 하지만 이번 연구에서는 연구범위가 'SDGs 자체에 대한 인권기준과 취약계층별 연계성 수준' 으로 국한함에 따라 이번 장에서는 UPR 권고사항 자체에 대한 SDGS와의 연계 시도는 다루지 않고 9개 취약계층 그룹별로 어떠한 연계성을 지니는지 살펴보는 정도로 한정함을 밝힌다. 동 연구에서 ‘취약계층별 SDGs 연계성 수준'을 살펴보는 취지 자체가 사업을 기획할 때 각 취약계층별 인권요소를 어떻게 사업에 접목시킬것인가에 대한 참고예시를 보여주기 위한 것이라는 점을 고려하였을 때, 동 UPR 데이터베이스에서 제공하는 다양한 내용 중 취약계층별 SDGs 연계성 부문에만 국한한다.

14) OCHR의 보편적인권지수(universal human rights index) 결과는 다음에서 확인가능하다. http://uhri.ohchr.org/en (접속일:2018.05.10.) 
이에 저자는 동 분석에서 UPR 데이터베이스가 제공하는 1,2 기 UPR권고사항 55,000 개를 대상 상기 9개 취약계층 분류에 따라 SDGs 목표 및 세부목표를 개괄적으로 살펴보고자 한다. 실제 권고를 받은 회원국이 국내이행 여부를 승낙(accepted) 권고들을 대상으로 SDGs 각 목표별로 얼마나 연결되어 있는지를 살펴보았다. 또한 SDGs 세부목표 차원에서 보았을 때, UPR 권고사항 중에서 가장 많이 연계되어 있는 SDGs 세부목표가 무엇인지를 살펴보기 위해 동 결과를 상위 7개로 제시하였으며, 이는 회원국의 국내적용을 승낙(accepted)한 권고안 뿐만 아니라 아직 적용계획은 없으나 다른 검토국가들로부터 제안 받은(noted) 권고안까지 모두 포함하여 제시하였다.15)

\section{2. 분석 결과}

\section{1) 개괄}

아래 <표 6>은 9개 취약계층이 SDGs 세부목표와 얼마나 연결되어 있는지, 그리고 지난 1,2 기에 걸쳐 UPR에서 제시된 전체 권고안(recommendation) 55,000개를 대상으로 각 취약 계층별로 살펴보았을 때 SDGs 세부목표와 얼마나 연결되는지를 나타낸 표이다. 동 표에서 확인할 수 있는 바와 같이 전체 UPR권고사항을 가지고 분류해봤을 때 인권활동 과정에서 스스로의 인권을 보호받지 못하는 '인권옹호자(human rights defenders)' 그룹을 비롯해 여성과 소녀(women and girls), 아동(children), 소수집단(members of minorities), 토착민 (indigenous people) 그룹은 SDGs 세부목표와 60\%이상의 매핑율을 보인다. 반면 피난민 (Refugees and asylum-seekers) 그룹은 매핑률이 30\% 미만으로, 국내실향민(internally displaced persons), 장애인(persons with disabilities), 이민자(migrants) 등은 40\% 미만의 매핑률을 보인다. 이는 아동, 여성과 소녀 등의 이슈의 경우 별도의 SDG3(보건) SDG4(교육), $\mathrm{SDG5}$ (성평등) 등 직접적인 목표로 제시되는 동시에 일반적으로 인권기반 사업에서 가장 많이 고려되는 그룹이라는 점에서 SDGs세부목표와의 연결성 또한 높게 나온 반면, 실향민, 이민자, 피난민 등의 이슈는 인권이슈와 함께 내정간섭 등의 이슈와도 연계되는 민감한 이슈라는 점에서 $\mathrm{SDGS}$ 와의 연계를 통한 접근 방식 또한 비교적 저조하다고 할 수 있다.

15) 동 연구에서는 지면의 한계상 SDGs 세부목표와 취약계층별 연계성을 상위 7 개 수준으로 제시하였지만, 동 UPR 데이터베이스에서 각 취약계층별 어떠한 SDGs 세부목표와 연계되는지에 대해 csv파일형태로 제공하고 있다. 이는 다음에서 확인가능하다. http://upr.humanrights.dk/groups (접속일: 2018.05.10.) 
〈표 6〉취약계층 기준별 UPR권고사항 및 SDGs 연계 현황16)

\begin{tabular}{|c|c|c|c|}
\hline 취약계층 분류 & $\begin{array}{l}\text { UPR } \\
\text { 총권고수 }\end{array}$ & $\begin{array}{c}\text { 반영률 } \\
\text { (accepted) }\end{array}$ & $\begin{array}{l}\text { SDGs 세부목표 } \\
\text { 매핑율 }\end{array}$ \\
\hline 아동(children) & 7,584 & $88 \%$ & $63 \%$ \\
\hline $\begin{array}{l}\text { 인권옹호자 } \\
\text { (human rights defenders) }\end{array}$ & 435 & $30 \%$ & $78 \%$ \\
\hline 토착민(indigenous people) & 1,245 & $83 \%$ & $63 \%$ \\
\hline $\begin{array}{l}\text { 국내실향민 } \\
\text { ((internally displaced persons) }\end{array}$ & 169 & $86 \%$ & $37 \%$ \\
\hline $\begin{array}{l}\text { 소수집단 } \\
\text { (members of minorities) }\end{array}$ & 4,544 & $82 \%$ & $64 \%$ \\
\hline 이민자(migrants) & 1,589 & $81 \%$ & $39 \%$ \\
\hline $\begin{array}{l}\text { 장애인 } \\
\text { (persons with disabilities) }\end{array}$ & 1,504 & 92\% & $38 \%$ \\
\hline $\begin{array}{l}\text { 피난민 } \\
\text { (Refugees and asylum-seekers) }\end{array}$ & 498 & $79 \%$ & $28 \%$ \\
\hline 여성과 소녀(women and girls) & 11,302 & $89 \%$ & $77 \%$ \\
\hline
\end{tabular}

출처: SDGs-UPR데이터베이스(upr.humanrights.dk/groups) (접속일: 2018.05.10.)

동 취약계층별 분석 결과는 각 SDGs 목표(goals)와의 연계현황 및 높은 연결성을 보이는 세부목표 상위 7개를 개괄적으로 읽어주는 수준으로 제시함으로써 각 취약계층별 SDGs 연계성에 대한 전반적인 이해를 도모하고자 한다.

\section{2) 아동(children)}

먼저 첫 번째, 아동(children)의 경우를 보면 1,2 기 전체에 걸쳐 제기된 총 UPR권고수는 7,584 개에 달한다. 아래 <그림 2>에서와 같이 아동 그룹과 가장 높은 연계성을 보이는 목표는 $\mathrm{SDG} 16$ (평화 및 거버넌스), SDG8(일자리), SDG4(교육), SDG5(성평등) 등의 목표가 높은 연관성을 보이는 동시에 권고안에 대한 이행 승낙(accept) 비율도 높음을 알 수 있다. 반면 $\mathrm{SDG} 7$ (에너지), SDG12(생산과 소비), SDG14(해양생태계), SDG15(육상상태계)에서는 아동 관련 UPR 권고사항이 제시되지 않음에 따라 SDGs 세부목표와의 연계가 '0'으로 나타났다.

16) 또한 동 데이터베이스에서 각 취약그룹별로 제시하고 있는 UPR 총권고수(recommendation) 및 반영률(accepted)의 수치와 실제 제시되어 있는 그래프상의 수치 합산이 일치하지 않음에 따라 동 표는 실제 그래프상의 수치를 기준으로 작성하였음을 밝힌다. 동 표에 대한 상세 총괄표는 '[붙임2] SDGs 각 세부목표별 취약그룹 연계 현황 총괄표'를 참조하기 바란다. 
〈그림 2〉SDGs 목표별 '아동' 그룹 관련 연결 분포

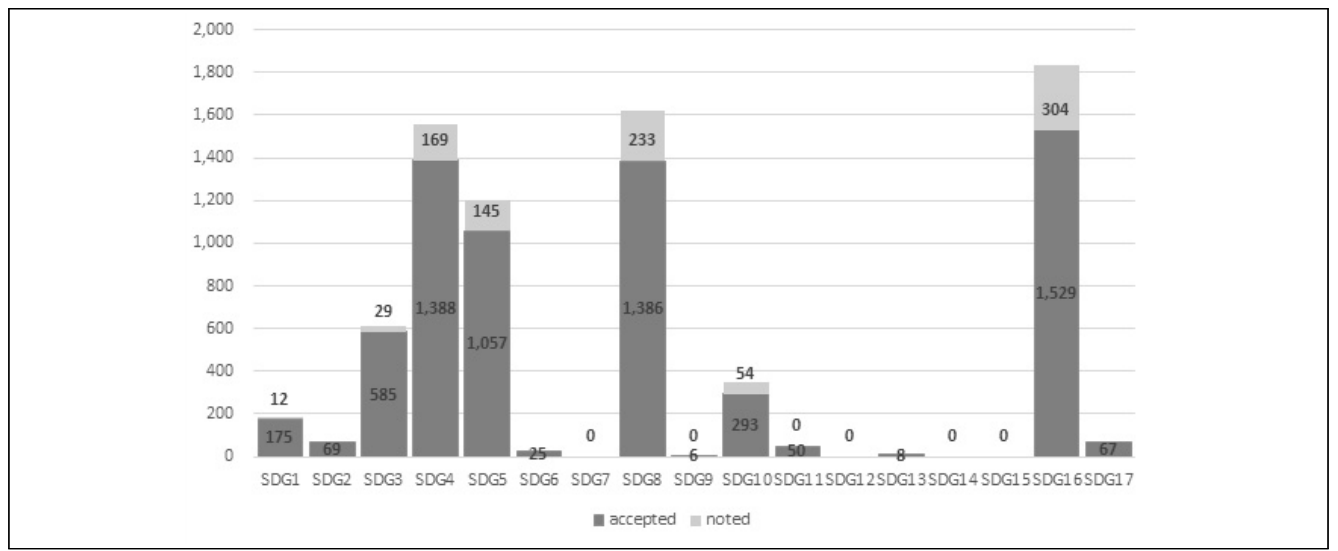

출처: SDGs-UPR데이터베이스(upr.humanrights.dk/groups) 바탕으로 저자 재구성 (접속일: 2018.05.10.)

반면 아래 <그림 $3>$ 에서와 같이 세부목표 차원에서 보면 가장 높은 연계성을 보이는 상위 7 개 세부목표 중 4개가 SDG4(교육)과 연관됨을 알 수 있다. 모든 학습자가 지속가능 개발 촉진에 필요한 지식과 기술을 획득하도록 보장하고(4.7), 모든 소녀와 소년이 양질의 초등 및 중등 교육을 이수하도록 보장(4.1)하며, 아동을 비롯한 모두를 위한 안전하고 비폭력적이며 포용적이고 효과적인 학습환경 제공(4.a)해야한다는 내용이 UPR 권고안 중에서 가장 많이 제시된 것이다. 아울러 모든 여성과 소녀에 대한 모든 형태의 폭력 근절(5.2), 아동에 대한 모든 형태의 폭력과 고문 종식(16.2), 모든 형태의 아동노동 종식(8.7)이 그 다음으로 가장 많은 연관성을 보이는 등, 상위 7 개 세부목표가 취약계층 중에서도 아동 관련 인권개선을 위해서 가장 우선적으로 해결되어야 할 부분이라고 할 수 있다.

〈그림 3〉 '아동' 그룹 관련 UPR 권고안 대상 연결도 상위 7개 SDGs 세부목표

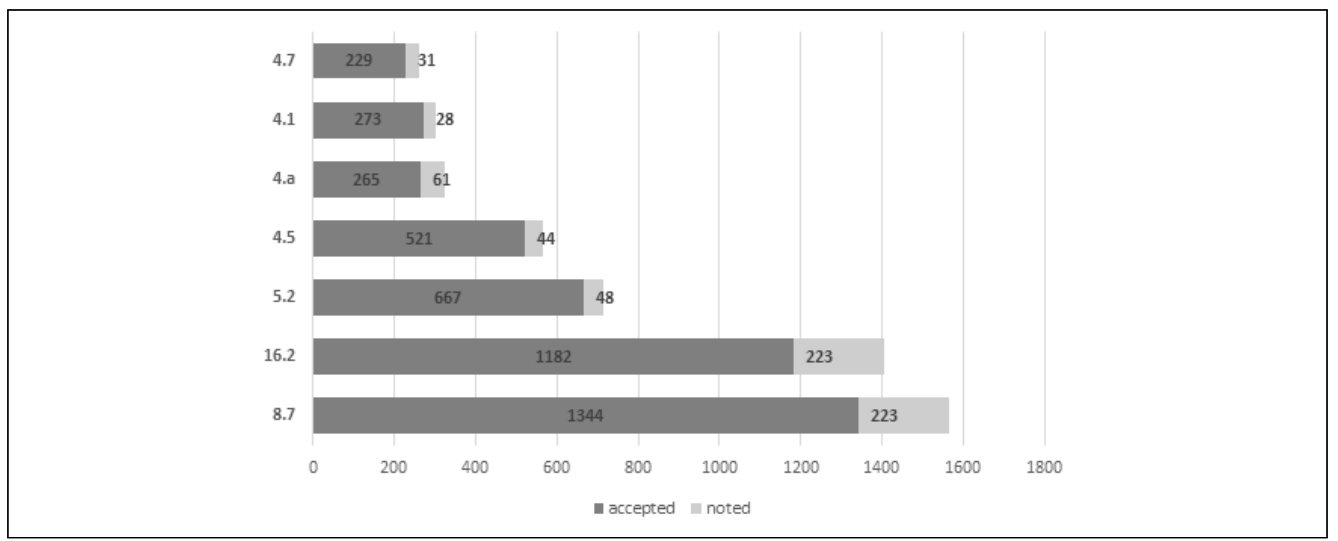

출처: SDGs-UPR데이터베이스(upr.humanrights.dk/groups) 바탕으로 저자 재작성 (접속일: 2018.05.10.) 


\section{3) 인권옹호자(human rights defenders)}

인권옹호자 그룹의 경우 총 435 의 UPR 권고안이 1,2 기 동안 제기되었으며, 아래 <그림 $4>$ 에서와 같이 동 그룹은 $80 \%$ 이상의 권고안이 SDG16(평화와 거버넌스)와 연관되어 있음을 알 수 있다. 이 외에도 SDG8(일자리), SDG5(성평등), SDG10(불평등) 목표와도 낮은 정도지만 연결성을 보이고 있다.

\section{〈그림 4〉 SDGs 목표별 '인권옹호자' 그룹 관련 연결 분포}

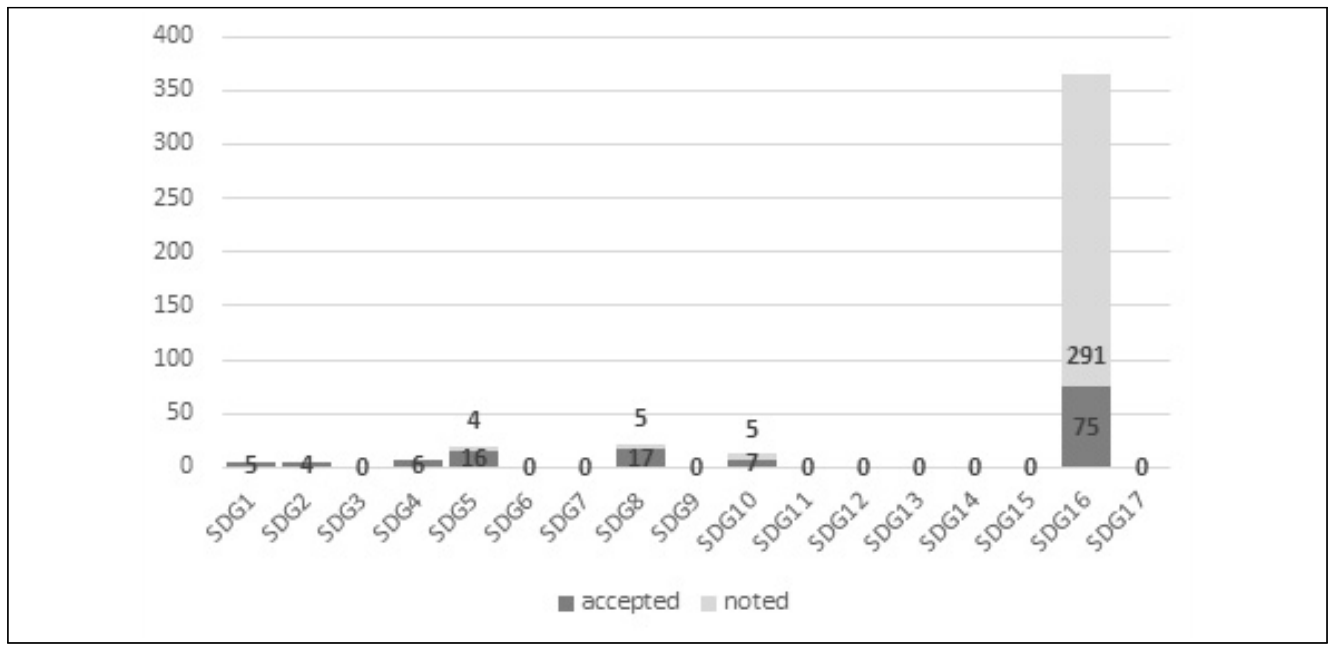

출처: SDGs-UPR데이터베이스(upr.humanrights.dk/groups) 바탕으로 저자 재작성 (접속일: 2018.05.10.)

동 '인권옹호자' 그룹의 경우 높은 연계성을 보이는 상위 7개 세부목표 중 5개가 모두 SDG16 (평화와 인권)과 연계되어 있으며, 관련하여 제기된 UPR권고안의 대다수가 SDG6.10 (국내법과 국제협정에 따라 정보에 대한 대중의 접근을 보장하고, 기본적 자유를 보호)에 해당함을 알 수 있다. 이 외에도 법치를 증진하고 모두에게 정의에 대한 평등한 접근 보장(16.3), 포용적이며 참여적이고 대표성 있는 의사결정 보장(16.7), 모든 형태의 폭력 및 관련 사망률 감축(16.1), 개도국 내 폭력 및 테러, 범죄 예방을 위한 역량 구축(16.a), 모든 여성과 소녀에 대한 모든 형태의 폭력 근절(5.2), 이주노동자를 비롯한 모든 근로자의 노동권 보호 및 안정적 근로환경 증진(8.8) 등이 인권 옹호 활동자들의 활동에 있어 상대적으로 가장 많은 UPR 권고사항으로 제기되었으며, SDGs에서도 이러한 세부목표들을 중심으로 연계되어 있음을 알 수 있다. 
〈그림 5〉 '인권옹호자' 그룹 관련 UPR 권고안 대상 연결도 상위 7개 SDGs 세부목표

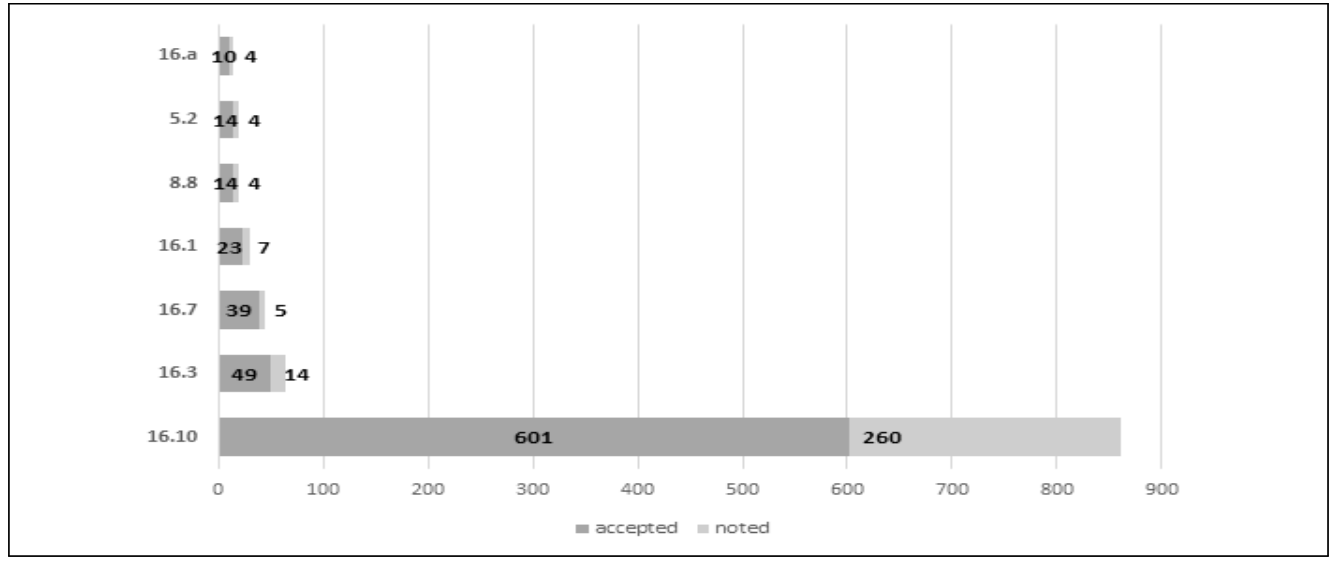

출처: SDGs-UPR데이터베이스(upr.humanrights.dk/groups) 바탕으로 저자 재작성 (접속일: 2018.05.10.)

\section{4) 토착민((Indigenous people)}

토착민 그룹과 관련한 UPR 권고안은 총 1,245 개가 제기되었으며, 동 이슈는 SDGs의 다양한 목표들에 비교적 골고루 연계되어 있다. 하단의 <그림 6>에서와 같이 토착민 그룹은 SDG16 (평화 및 거버넌스)와 가장 높은 연계를 보이지만 나머지 목표들인 SDG1(빈곤), SDG2(기아), $\mathrm{SDG} 10$ (불평등), SDG4(교육), SDG5(성평등)을 비롯해 기타 목표들에도 상대적으로 높은 연관성을 보이고 있다. 반면 SDG7(에너지), SDG9(산업), SDG14(해양생태계), SDG15(육상 생태계)에서는 관련 UPR 권고사항이 제기되지 않았음을 알 수 있다.

〈그림 6〉'토착민' 그룹 대상 SDGs 목표(goals) 연결 분포

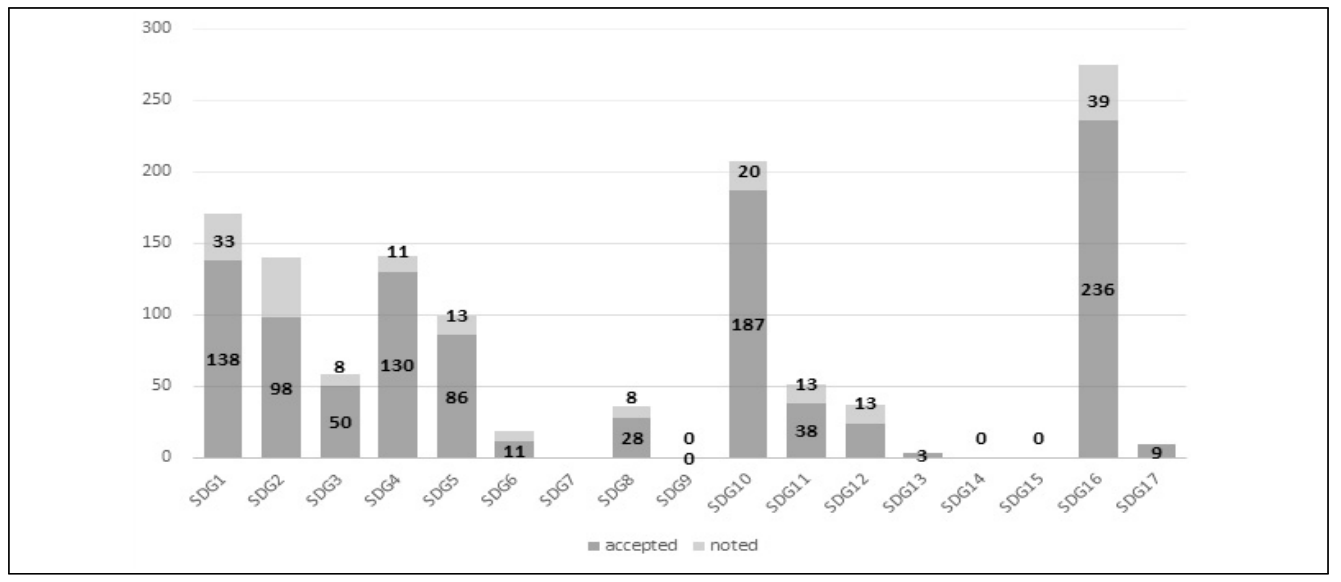

출처: SDGs-UPR데이터베이스(upr.humanrights.dk/groups) 바탕으로 저자 재작성 (접속일: 2018.05.10.) 
$\mathrm{SDGS}$ 세부목표 차원에서 보면 SDG10.3(차별적 법 및 정책근절을 통해 평등한 기회 보장 및 결과의 불평등 완화)와 관련하여 토착민에 적용될 수 있는 UPR 권고사항이 가장 많이 제기되었음을 알 수 있다. 이 외에도 모든 수준에서 포용적이고 참여적이며 대표성 있는 의사결정권 보장 (16.7), 토착민을 비롯한 취약계층의 농업생산성 및 소득을 두배 증대(2.3), 모든 남성과 여성의 금융서비스에 대한 접근성 보장(1.4), 토착민을 비롯한 취약계층에 대해 모든 수준의 교육 및 직업훈련에 대한 평등한 접근권 보장(4.5), 모두에 대한 필수의약품 및 백신에 대한 접근을 비롯한 보편적 의료보장 달성(3.8), 모든 여성과 소녀에 대한 모든 형태의 폭력 근절(5.2) 등이 토착민 그룹과 관련하여 SDGs와 높은 연관성을 보이고 있다.

\section{〈그림 7〉 '토착민' 그룹 대상 연계도 기준, 상위 7개 SDGs 세부목표}

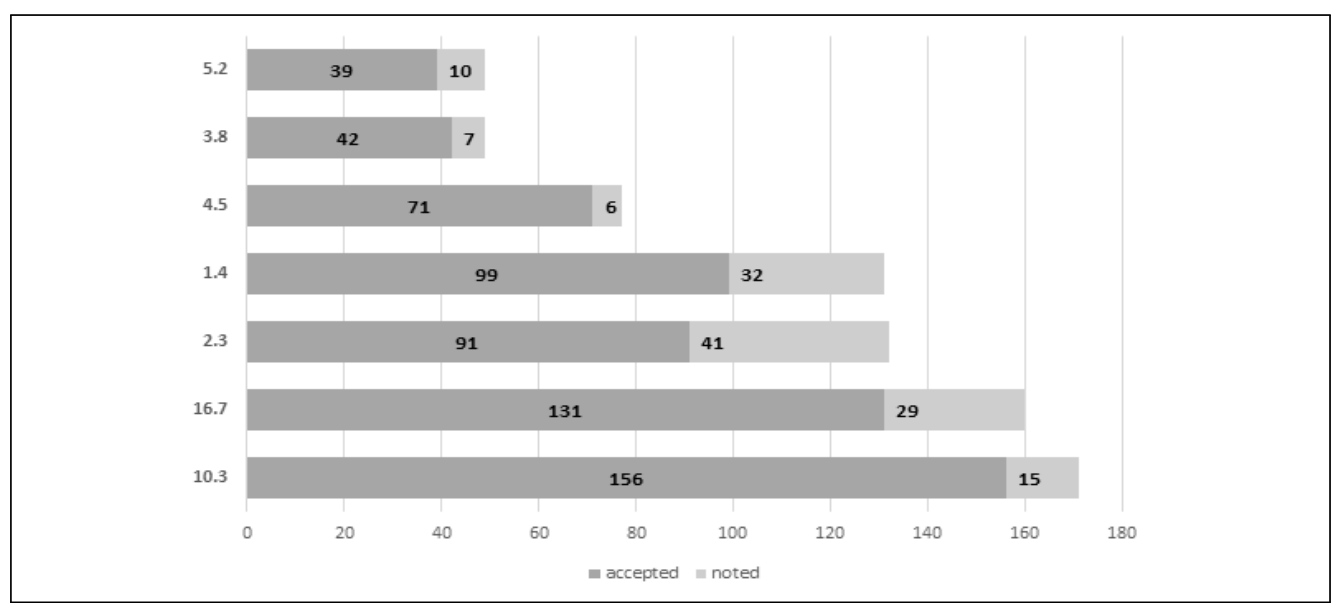

출처: SDGs-UPR데이터베이스(upr.humanrights.dk/groups) 바탕으로 저자 재작성 (접속일: 2018.05.10.)

\section{5) 국내실향민(Internally Displaced Persons, IDP)}

국내실향민 그룹과 관련해서는 전체 UPR권고사항 중에서 169 개가 제기되었으며, 제기된 전체 권고안 개수는 많지 않으나 동 이슈 또한 SDGs 세부목표들과 비교적 골고루 연계되어 있음을 알 수 있다. 하단 <그림 8>에서와 같이 국내실향민 그룹의 경우 SDG16(평화와 거버넌스)와 $\mathrm{SDG} 11$ (도시)와 가장 높은 연관성을 보이고 있으며 이 외에도 SDG1(빈곤), SDG5(성평등), $\mathrm{SDG10}$ (불평등)과도 비교적 뚜렷한 연관성을 보이고 있다. 반면 SDG7(에너지), SDG12(생산과 소비), SDG14(해양생태계), SDG15(육상생태계)와 관련해서는 별도의 UPR 권고안이 제기되지 않았음이 확인된다. 
〈그림 8〉 '국내실향민' 그룹 대상 SDGs 목표(goals) 연결 분포

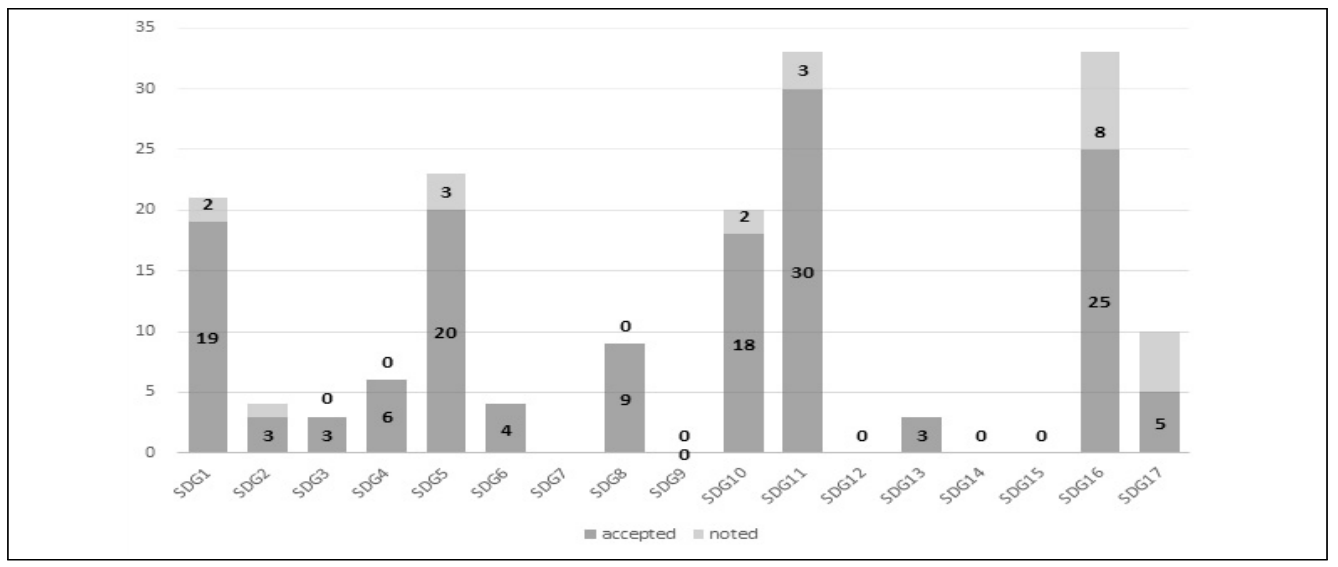

제I장

\section{제II장}

섹

터

포

커

$\underline{\underline{ }}$

제피장

출처: SDGs-UPR데이터베이스(upr.humanrights.dk/groups) 바탕으로 저자 재작성 (접속일: 2018.05.10.)

하단 <그림 9>에서 확인되는 바와 같이, SDGs 세부목표 차원에서 보면 총 33개 UPR권고안이 연관성을 보였던 SDG11(도시) 중에서 29개 권고안이 SDG11.1(2030년까지 모두가 저렴한 주택 및 기초서비스에 대한 접근을 보장하고 빈민가 개선)과 관련함을 알 수 있다. 또한 SDG5(성평등)과 관련해서도 총 23 개 권고안이 제기되었는데 이 중 18 개가 모든 여성과 소녀에 대한 모든 형태의 폭력 근절(5.2)와 연결되고 있다. 이 외에도 모든 남성과 여성, 특히 빈곤층과 취약계층은 금융 서비스에 대한 동등한 접근권을 보장(1.4), 2030년까지 출생신고를 비롯해 모두에게 법적 정체성 부여(16.9), 2030년까지 모든 사람의 사회, 경제, 정치적 포용을 강화하고 증진(10.2), 모든 형태의 아동노동 종식(8.7), 아동에 대한 모든 형태의 폭력과 고문 종식(16.2)이 국내 실향민 그룹과 관련하여 주요하게 제기되었다.

\section{〈그림 9〉 '국내실향민' 그룹 대상 연계도 기준, 상위 7개 SDGs 세부목표}

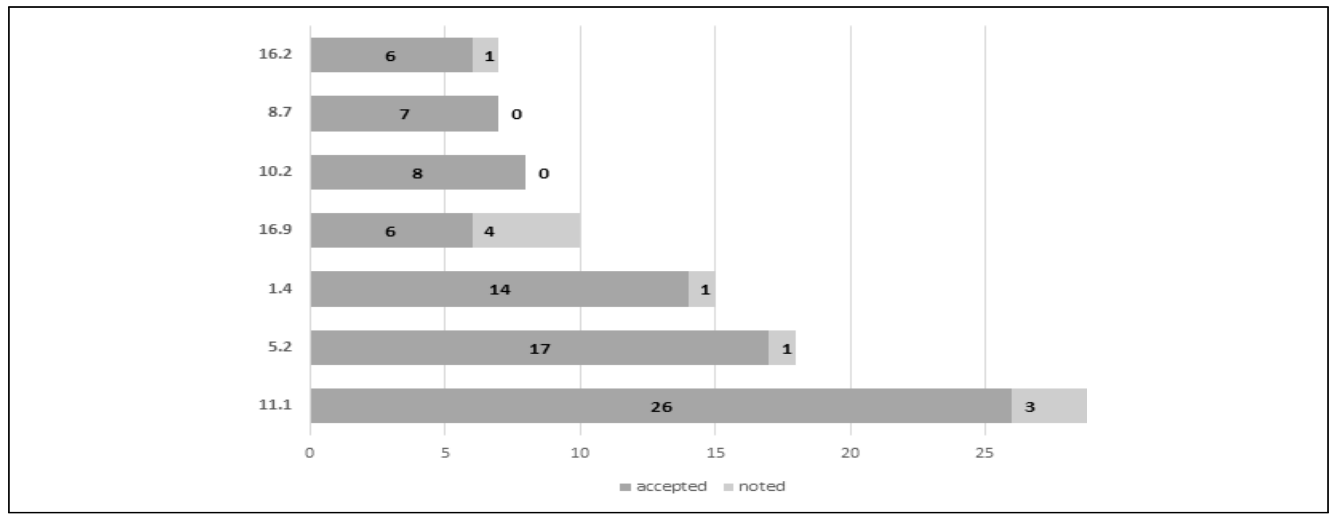

출처: SDGs-UPR데이터베이스(upr.humanrights.dk/groups) 바탕으로 저자 재작성 (접속일: 2018.05.10.) 


\section{6) 소수집단(members of minorities)}

다음으로 소수집단(members of minorities) 그룹을 보면, 총 4,555개의 UPR 권고안이 제기되었는데 이는 총 9 개 그룹 중 3 번째에 이를 만큼 높은 비중을 차지한다고 할 수 있다. 그 중에서도 특히 소수집단과 관련한 UPR권고안은 SDG10(불평등)과 가장 높은 연계성을 뚜렷하게 보이고 있으며 이는 약 50\%의 비율을 차지하고 있다. 이 외에도 SDG4(교육), SDG16(평화 및 거버넌스)와 관련하여 어느정도 연관성을 보이는 반면, SDG7(에너지), SDG9 (산업), SDG12(생산과 소비), SDG13(기후변화), SDG14(해양생태계), SDG15(육상생태계)와 관련해서는 별도 UPR권고안이 제기된 바 없음을 알 수 있다.

\section{〈그림 10〉 '소수집단' 그룹 대상 SDGs 목표(goals) 연결 분포}

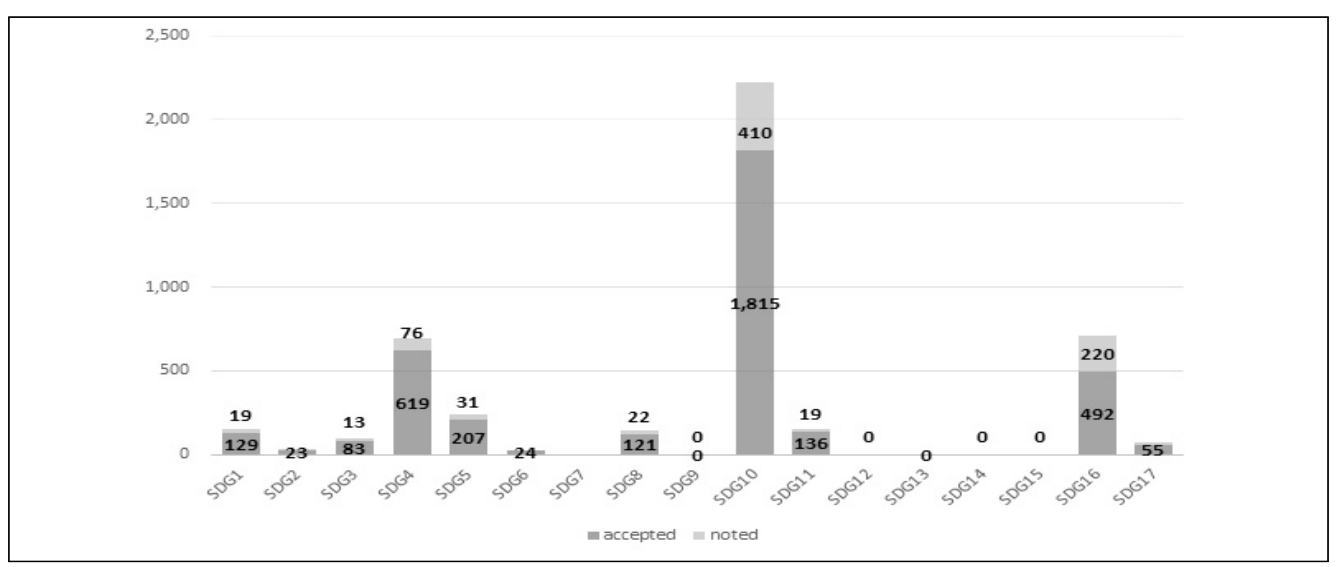

출처: SDGs-UPR데이터베이스(upr.humanrights.dk/groups) 바탕으로 저자 재작성 (접속일: 2018.05.10.)

$\mathrm{SDGs}$ 세부목표 차원에서 살펴보면 가장 높은 연관성을 보였던 SDG10(불평등)의 세부목표 10.3 (차별적 법 근절을 통해 평등한 기회를 보장하고 결과의 불평등 완화)가 압도적인 비중으로 높은 연관성을 보이고 있다. SDG10 차원에서도 85\% 이상의 UPR권고안이 SDG10.3과 연관 되어 있는 것이다. 이 외에는 미비한 비율이긴 하지만 아동을 포함한 취약계층에 대해 모든 수준의 교육 및 직업훈련에 대한 평등한 접근 보장(4.5), 모든 사람들의 사회, 경제, 정치적 포용을 강화 및 증진(10.2), 모든 학습자가 지속가능 개발 촉진을 위한 지식과 기술을 획득할 수 있도록 보장(4.7), 국내법과 국제법 정보에 대한 대중의 접근 보장 및 기본적 자유 보호 (16.10), 모두를 위한 안전하고 포용적이고 효과적인 학습 환경 제공(4.a), 모두에게 저렴한 주택 및 기초서비스에 대한 접근성을 보장하고 빈민가를 개선(11.1)이 가장 높은 연관성을 보이고 있다. 


\section{〈그림 11〉 '소수집단' 그룹 대상 연계도 기준, 상위 7개 SDGs 세부목표}

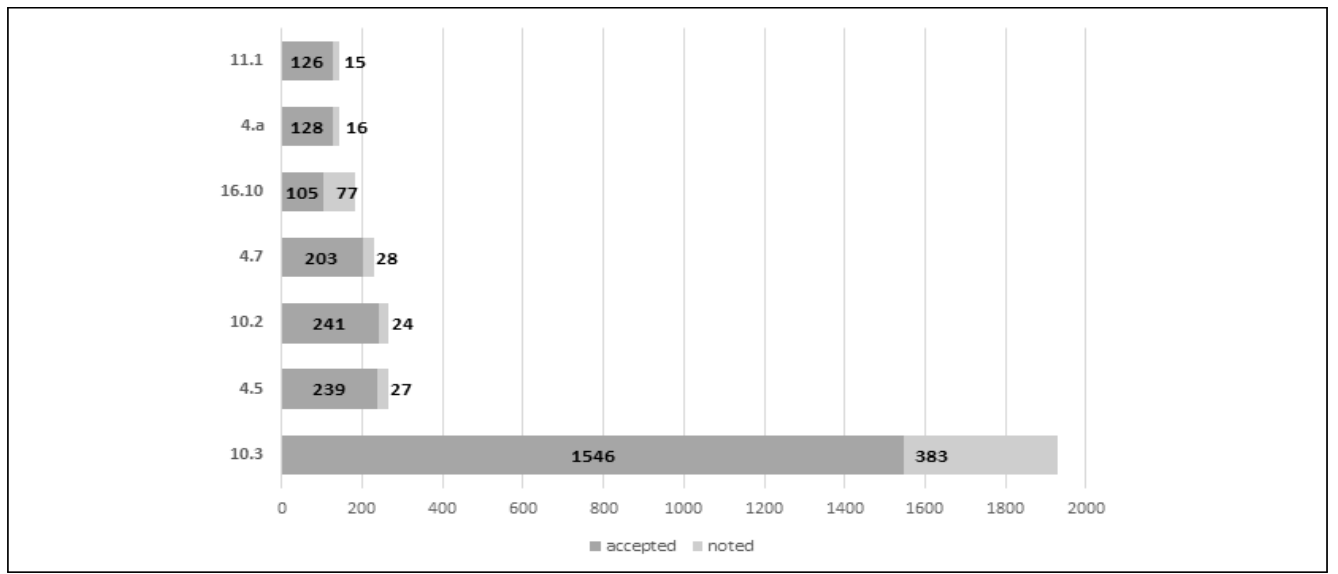

\section{제 I 장}

\section{제II장}

섹

터

포

커

$\underline{\underline{ }}$

제피장

출처: SDGs-UPR데이터베이스(upr.humanrights.dk/groups) 바탕으로 저자 재작성 (접속일: 2018.05.10.)

\section{7) 이민자(migrants)}

이민자(migration) 그룹의 경우 전체 UPR 권고사항 중 1,589 개가 관련하여 제시되었으며, <그림 12>에서와 같이 SDGs와 관련해서는 SDG10(불평등), SDG8(일자리)와 관련하여 가 장 높은 연관성을 보인다. 특히 이민자 그룹과 관련한 전체 UPR 권고사항 중 두 목표가 차지하 는 비중은 2/3에 이르는 수준이다. 이 외에도 SDG16(평화와 거버넌스), SDG4(교육), SDG5 (성평등), SDG1(빈곤) 등의 기타 목표와도 연관성을 보인다. 반면 SDG7(에너지), SDG12(생 산과 소비), SDG14(해양생태계), SDG15(육상생태계)에 대해서는 이민자 그룹과 관련하여 제시된 $\mathrm{UPR}$ 권고사항이 없다.

\section{〈그림 12〉'이민자' 그룹 대상 SDGs 목표(goals) 연결 분포}

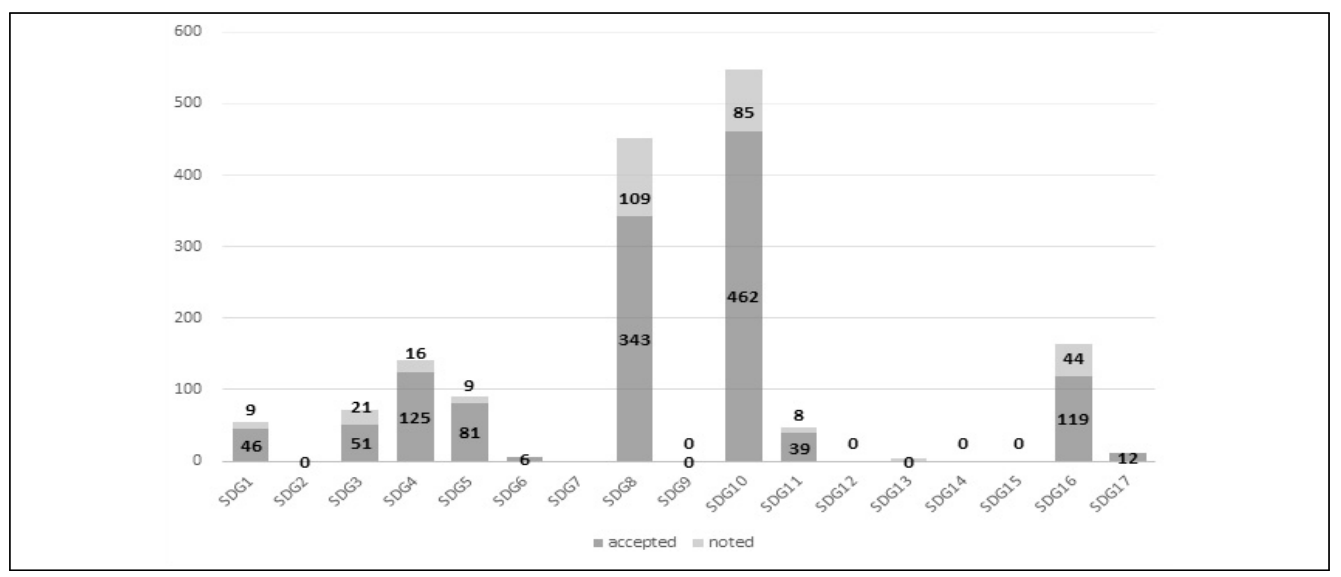

출처: SDGs-UPR데이터베이스(upr.humanrights.dk/groups) 바탕으로 저자 재작성 (접속일: 2018.05.10.) 
$\mathrm{SDGS}$ 세부목표 차원에서 보면 역시 SDG10(불평등)과 SDG8(일자리)와 관련하여 SDG10.3 (차별적 법 및 정책 근절을 통한 평등한 기회 보장 및 결과의 불평등 완화)와 SDG8.8(이주근로자를 포함한 모든 근로자의 노동권을 보호하고, 안정적인 근로환경 증진)이 가장 높은 연관성을 보이고 있다. 이 외에도 잘 계획된 이주정책 이행을 통해 사람들의 안전하며 책임있는 이주와 이동 촉진(10.7), 모든형태의 아동노동 종식(8.7), 모든 취약계층에 대해 교육 및 직업훈련에 대한 평등한 접근권 보장(4.5), 모두에게 양질의 저렴한 필수 의약품과 백신에 대한 접근을 비롯한 보편적 의료보장달성(3.8), 모든 여성과 소녀에 대한 모든 형태의 폭력 근절(5.2)가 이민자 그룹 관련하여 가장 많이 제기된 UPR 권고사항이다.

〈그림 13〉 '이민자' 그룹 대상 연계도 기준, 상위 7개 SDGs 세부목표

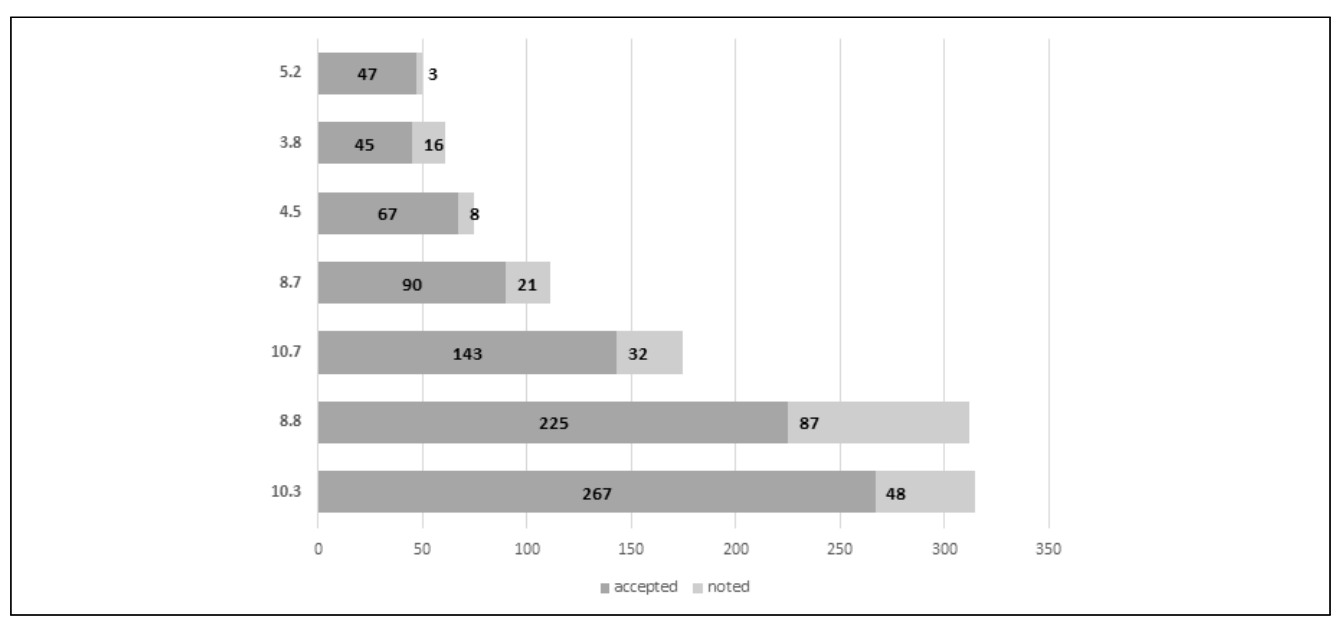

출처: SDGs-UPR데이터베이스upr.humanrights.dk/groups) 바탕으로 저자 재작성 (접속일: 2018.05.10.)

\section{8) 장애인(persons with disabilities)}

장애인 그룹 관련 UPR권고사항은 총 1,504 개가 제기되었으며, 아래 <그림 14 >에서와 같이 SDGs 목표(goals) 중에서 가장 높은 연관성을 보이는 것은 SDG4(교육)이다. 이 외에도 SDG10 (불평등), SDG8(일자리), SDG16(평화와 거버넌스)가 비교적 높은 연관성을 보이며, 반대로 $\mathrm{SDG7}$ (에너지), SDG12(생산과 소비), SDG14(해양생태계), SDG15(육상생태계)와 관련해서는 별도 UPR 건고사항이 제시되지 않았다. 
〈그림 14〉 '장애인' 그룹 대상 SDGs 목표(goals) 연결 분포

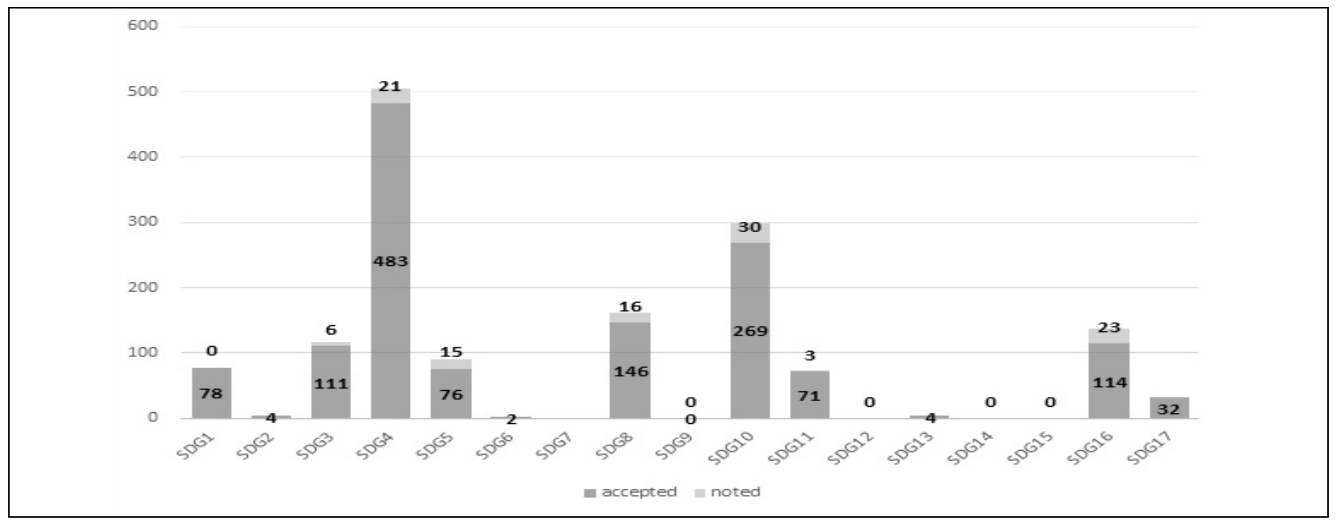

출처: SDGs-UPR데이터베이스(upr.humanrights.dk/groups) 바탕으로 저자 재작성 (접속일: 2018.05.10.)

$\mathrm{SDGs}$ 세부목표 차원에서 보면 장애인 그룹 관련하여 제기된 UPR 권고사항 중에 가장 높은 연계율을 보이는 세부목표 두 개 모두 SDG4(교육)과 관련하고 있다. SDG4.5(장애인을 포함한 모든 취약계층에 대한 교육 및 직업훈련에 대한 평등한 접근 보장) 및 SDG4.a(아동, 장애, 성 인지적 교육시설을 구축하고 포용적인 학습환경 조성)이 전체 장애인 그룹 관련 UPR 권고사항 수 대비 30\%정도를 차지한다. 그 외에도 차별적 법 및 정책 근절을 통한 평등한 기회를 보장하고 결과의 불평등 완화(10.3), 장애를 비롯한 모든 사람의 사회, 경제, 정치적 포용을 강화 및 증진(10.2), 모든 사람이 저렴한 필수 의약품과 백신에 대한 접근을 포함한 보편적 의료보장 달성(3.8), 모든 형태의 아동노동 종식(8.7) 등이 장애인 그룹 관련하여 제시된 UPR 권고사항 중에서 SDGs 와 가장 높은 연관성을 보이고 있다.

〈그림 15〉 '장애인' 그룹 대상 연계도 기준, 상위 7개 SDGs 세부목표

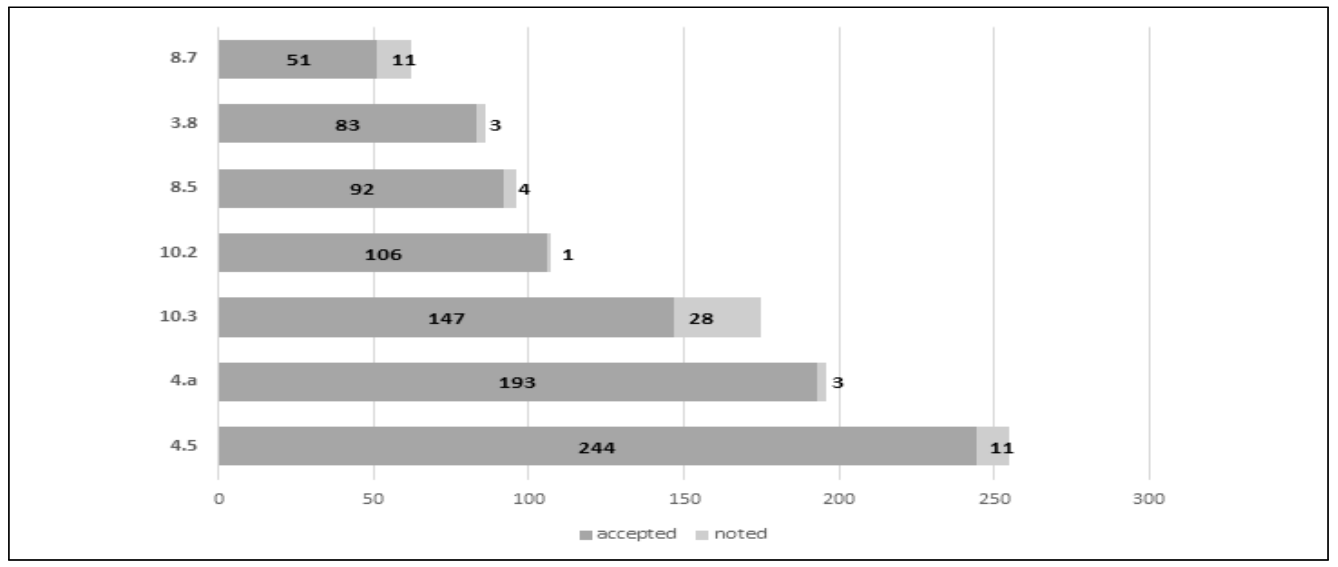

출처: SDGs-UPR데이터베이스(upr.humanrights.dk/groups) 바탕으로 저자 재작성 (접속일: 2018.05.10.) 


\section{9) 피난민(refugees and asylum-seekers)}

피난민 그룹과 관련해 제기된 전체 UPR 권고사항의 수는 498개로 그 수는 전체 권고안 총 수 대비 많지 않은 편이다. 하지만 <그림 $16>$ 에서와 같이, 피난민 그룹 자체에 대해 제시된 $\mathrm{UPR}$ 권고사항을 보면 SDG10(불평등)과 SDG16(평화 및 거버넌스)에 대해 매우 뚜렷한 연결성을 보이고 있다. 이 외에도 SDG1(빈곤), SDG3(보건), SDG4(교육), SDG5(성평등), SDG8(일자리), $\mathrm{SDG} 11$ (도시) 또한 피난민의 인권 개선을 위해 앞으로 해결해나가야할 주요 목표로서 함께 제시되고 있다. 하지만 이에 반해 SDG7(에너지), SDG9(산업), SDG12(생산과 소비), SDG14 (해양생태계), SDG15(육상생태계)와 관련해서는 피난민의 인권 개선과 관련한 UPR 권고사항이 별도로 제기되지 않았다.

〈그림 16〉'피난민' 그룹 대상 SDGs 목표(goals) 연결 분포

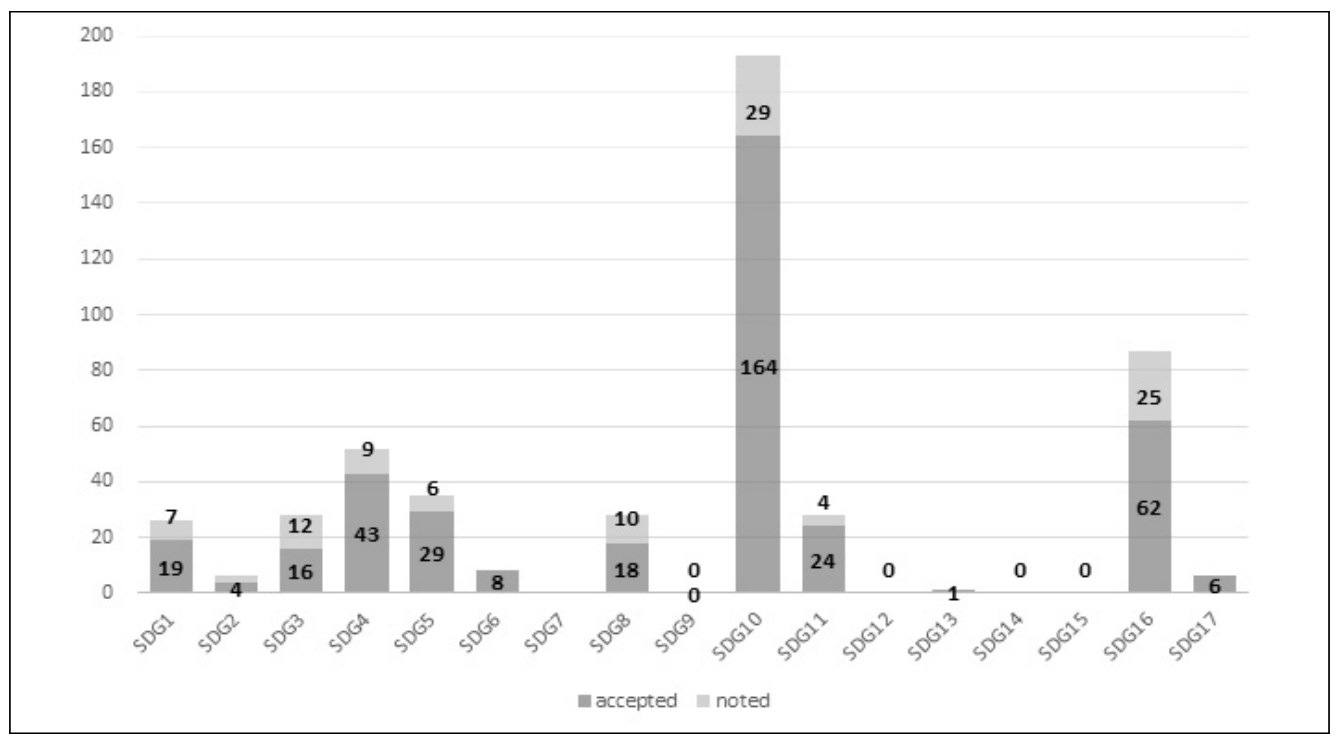

출처: SDGs-UPR데이터베이스 (upr.humanrights.dk/groups) 바탕으로 저자 재작성 (접속일: 2018.05.10.)

$\mathrm{SDGs}$ 세부목표 차원에서 보면 가장 높은 연관성을 보였던 SDG10(불평등)에서 역시 세부 목표 차원에서도 가장 높은 연관성을 보인다. SDG10.3(차별적 법 및 정책 근절을 통해 평등한 기회를 보장하고 결과의 불평등 완화), SDG10.7(잘 계획된 이주정책의 이행을 통해 사람들의 안전하고 책임있는 이주와 이동 촉진), 10.2 (민족, 출신, 종교 등 신분에 관계없이 모든 사람의 사회, 경제, 정치적 포용을 강화 및 증진)이 피난민 그룹과 관련하여 제기된 전체 UPR 권고사항 대비 약 $40 \%$ 의 비중을 차지한다. 그 외에도 취약계층에 대해 교육 및 직업훈련에 대한 평등한 접근 보장(4.5), 모두에 저렴한 주택 및 기초서비스에 대한 접근을 보장하고 빈민가 개선(11.1), 
출생신고를 포함해 모두에게 법적 정체성 부여(16.9), 모든 여성과 소녀에 대한 모든 형태의 폭력 근절(5.2)이 피난민 그룹 관련 제기된 UPR권고사항 중 SDGs와 가장 높은 연관성을 보인다.

〈그림 17〉 '피난민' 그룹 대상 연계도 기준, 상위 7개 SDGs 세부목표

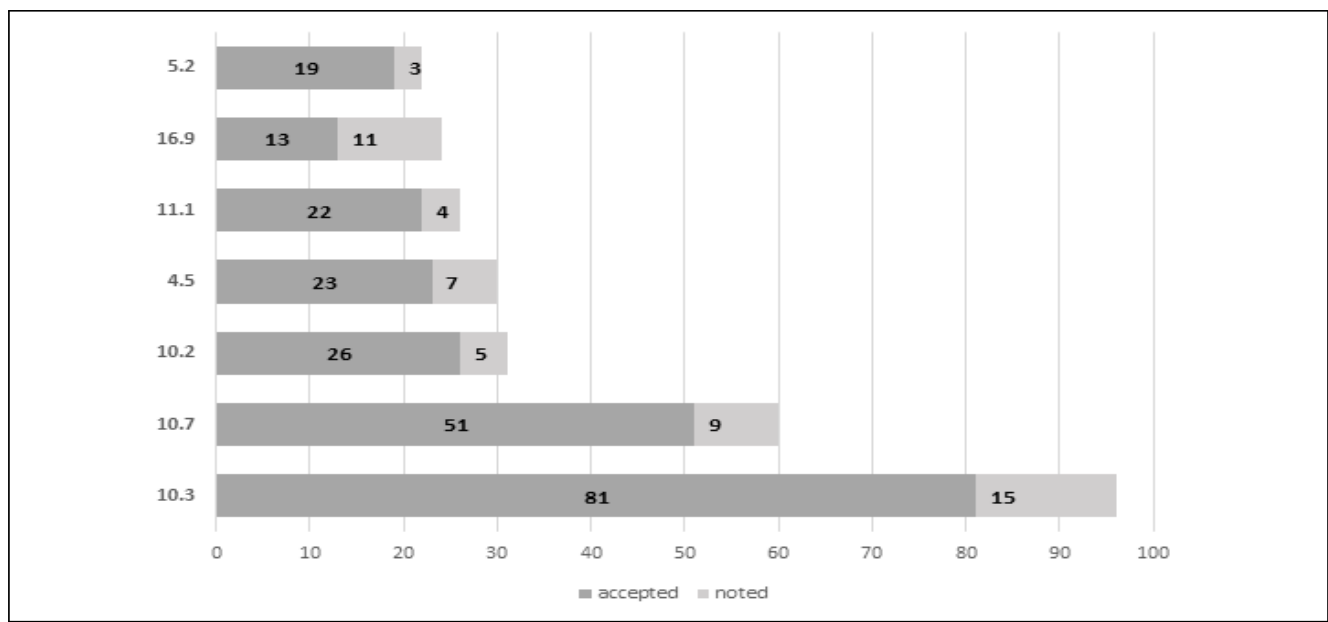

출처: 덴마크인권연구소(upr.humanrights.dk/groups) 바탕으로 저자 재작성 (접속일: 2018.05.10.)

10) 여성과 소녀(women and girls)

〈그림 18〉 '여성과 소녀' 그룹 대상 SDGs 목표(goals) 연결 분포

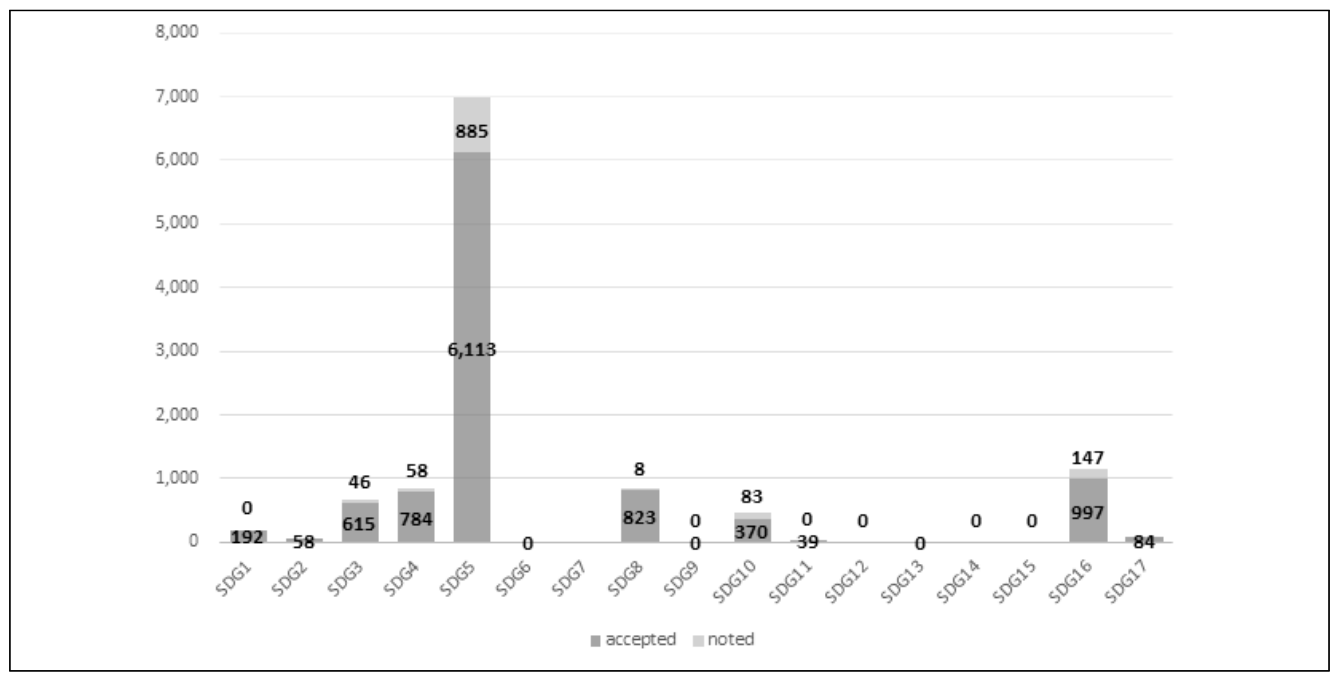

출처: SDGs-UPR 데이터베이스(upr.humanrights.dk/groups) 바탕으로 저자 재작성 (접속일: 2018.05.10.) 
마지막으로 여성과 소녀(women and girls) 그룹은 전체 취약계층 그룹 중 UPR 권고사항과 가장 높은 연계성을 보인 그룹으로, 총 11,302 개의 UPR권고사항이 여성과 소녀에 관한 내용이다. 동 이슈의 특성상 SDGs에서도 SDG5(성평등)에 압도적인 연관성을 보이며, 동 비중은 전체 대비 약 $60 \%$ 에 해당한다. 이 외에도 미비한 비중이기는 하나 SDG3(보건), SDG4(교육), SDG8(일 자리), SDG10(불평등), SDG16(평화와 거버넌스)와 관련하고 있으며, 반면 SDG6(물), SDG7 (에너지), SDG12(생산과 소비), SDG13(기후변화), SDG14(해양생태계), SDG15(육상생태계)와 관련해서는 별도로 여성과 소녀와 관련하여 제기된 UPR 권고사항이 없다.

\section{〈그림 19〉 '여성과 소녀' 그룹 대상 연계도 기준, 상위 7개 SDGs 세부목표}

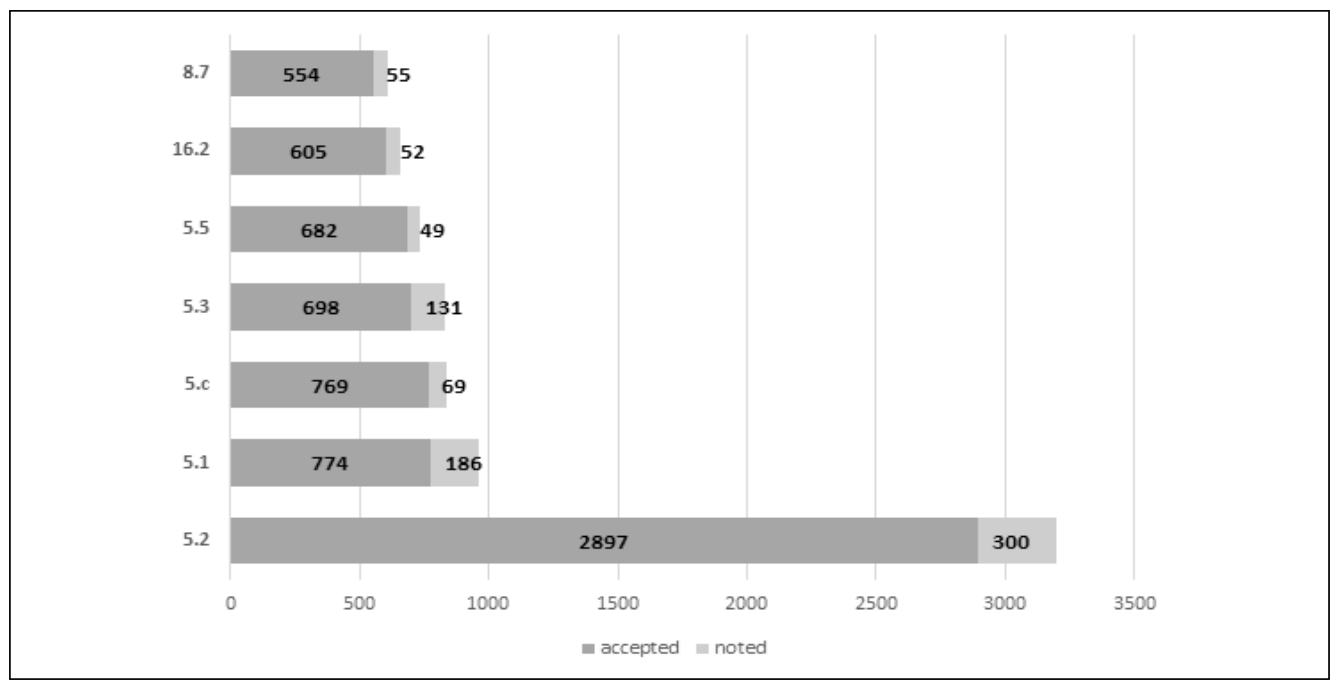

출처: SDGs-UPR데이터베이스(upr.humanrights.dk/groups) 바탕으로 저자 재작성 (접속일: 2018.05.10.)

SDGs 세부목표 차원에서 보면 상기 <그림 19 >와 같이 높은 연관성을 보이는 세부목표 역시도 SDG5(성평등)에 치중되어 있음을 알수 있다. 그 중에서도 가장 높은 연관성을 보이는 세부목표는 SDG5.2(모든 여성과 소녀에 대한 모든 형태의 폭력근절)이며, 5.1(모든 여성과 소녀에 대한 모든 형태의 차별 종식), 5.c(모든 수준에서의 양성평등 및 모든 여성과 소녀의 권익신장을 위한 정책 및 법 채택), 5.3(아동 결혼, 조혼 및 강제결혼, 여성 할례와 같은 모든 유해한 관습 근절), 5.5(정치, 경제, 공직생활 등 모든 의사결정 수준에서 여성의 참여 및 리더십 을 위한 평등한 기회 보장)이 모두 SDG5와 관련하여, 이 외에도 SDG16.2(아동에 대한 모든 형태의 폭력과 고문 종식), SDG8.7(모든 형태의 아동노동 종식) 또한 여성과 소녀 그룹과 관련해 높은 연관성을 보인다. 


\section{V. 향후 활용 방안 및 의의}

동 연구의 가장 큰 목적은 SDGs와 인권이 얼마나 상호 연계되었는지에 대해 SDGs 세부목표

(target) 수준에서 살펴봄으로써 SDGs와 인권의 통합적 이해를 도모하고자 하는 것이다. 최근 들어 국내에서 SDGs 내 인권기반접근법 적용의 필요성 및 국내 국제개발협력 정책 및 전략,

논의에 앞서 SDGs가 기본적으로 전제하고 있는 '보편적 인권(universal human rights)' 의 정신을 얼마나 잘 반영하고 있는지, SDGS에서 말하는 인권과 국제인권기준에서 말하는 인권이 얼마나 상호 부합되는지, 실제 상호 통합된 접근법(integrated approach)로 운영가능한 것인지에 대한 보다 기초적이고 세부적인 분석이 선제해야함에도 불구하고 이에 대한 논의는 활발하지 않은 것이 사실이다. 물론 SDGs와 인권을 연결하는 것은 국제사회에서도 주요 관심사이지만 그 작업 자체가 쉽지 않기 때문에 이에 대해 논의를 하는 것도 어려운 것이 사실이다. 하지만 본 고에서는 이러한 어려움에 대해 공감하지만 현재 국내에서 활발하게 논의가 되고 있는 인권 기반 접근법과 국제개발 정책 및 전략상의 인권 주류화 논의에 앞서 두 메커니즘이 얼마나 연결성을 가지는지에 대한 기초적인 접근을 현재 가능한 수준에서나마 시도해보고자 하였다.

덴마크인권연구소가 진행한 SDGs와 인권기준간의 연계작업이나 SDGs와 UPR 연계작업 시도 및 결과 자체가 완벽하다고는 할 수 없다. 하지만 이러한 두 메커니즘간의 연계 작업은 반드시 이루어져야 하며, 이에 대한 국제사회의 노력은 앞으로도 지속되어갈 것이다. 다만 국제사회에서의 이러한 연계 시도 자체도 현재는 초기 단계이고, 국내 각 국가들의 SDGs 이행 전략 내에 인권 기반 접근을 접목시키는 작업 자체도 현재로서는 초기단계에 있다고 할 수 있다. 따라서 앞으로 두 메커니즘을 하나의 통합된 방식으로 이행해나가기 위해서는 많은 시행착오 및 상호학습을 통한 개선과 보완작업이 지속적으로 이루어져야할 것이다. 이를 위해서는 각 국가 차원에서도 현재 국제사회에서 이루어지고 있는 연계시도의 흐름을 파악하고 국내 인권기반 SDGs 이행 전략 수립시 적극적으로 적용 가능성을 고려하고 평가함으로써 자국의 정책 및 전략의 개선을 위해 지속적으로 노력해나가야 한다. 또한 국가들이 이러한 노력을 지속해 나갈 때 전략 수립 및 사업 기획 과정을 넘어 향후 이행, 모니터링, 평가, 보고 등 일련의 과정에 대해서도 보다 하나의 통합된 접근방식을 가짐으로써 보다 실무적으로 시너지효과를 내는 동시에 국제인권의무 이행과 $\mathrm{SDGs}$ 이행 또한 보다 성공적으로 해낼 수 있게 될 것이다.

이러한 점에서 보았을 때, 본 고에서 시도한 두 메커니즘간의 연계성 고찰 시도는 단순히 취약계층에 대한 인권 고려, SDGs 내 인권기반 접근 반영 등과 같이 자칫 모호하게 논의될 
수 있는 주제들을 비교적 명확한 기준들을 바탕으로 보다 구체적으로 연결시켜 이해할 수 있는 출발점이자 기초자료(background paper)로 활용되기를 바란다. 


\section{〈참고 문헌〉}

곽재성 외 8인. 2017. 『KOICA사업의 취약계층 포괄적 접근 현황 평가』. 성남: 한국국제 협력단.

이성훈. 2017. “지속가능발전목표(SDGs)와 인권기반 개발협력” 『국제개발협력』2017-4호: 3-38.

Danish Institute for Human Rights. 2018. "Human Rights and the 2030 Agenda for Sustainable Development: Lessons learned and next step”. Copenhagen: Danish Institute for Human Rights.

UN. 2015a. "The road to dignity by 2030: ending poverty, transforming all lives and protecting the planet”. Synthesis Report of the Secretary-General on the Post-2015 Agenda (A/69/700). New York: United Nations (UN), available at http://www.un.org/en/development/desa/publications/files/2015/01/Synth esisReportENG.pdf (접속일: 2018.05.10.)

_. 2015b. "Transforming our world: the 2030 agenda for sustainable development" (A/RES/70/1). New York: United Nations, available at https://sustainable development.un.org/post2015/transformingourworld (접속일: 2018.05.10.)

URG. 2017. "Human Rights and the SDGs: Pursuing Synergies". Geneva: Universal Rights Group (URG), available at https://www.universal-rights.org/ wp-content/uploads/2017/12/RAPPORT_2017_HUMAN-RIGHTS-SDGSPURSUING-SYNERGIES_03_12_2017_digital_use_spread.pdf (접속일: 2018.05.10.)

덴마크인권연구소: http://humanrights.dk. (접속일:2018.05.10.)

'SDGs-인권연계 데이터베이스'(The Human Rights Guide to the Sustainable Development Goals): http://sdg.humanrights.dk/ (접속일: 2018.05.10.) 'SDGs-UPR 데이터베이스'(UPR-SDGs Data Explorer): http://upr.humanrights.dk/ (접속일: 2018.05.10.) 


\section{[부록 1] SDGs 각 세부목표별 국제인권기준 연계 현황 총괄표17)}

\section{- SDG1: 모든 곳에서 모든 형태의 빈곤 종식}

-SDG1 세부목표 중 인권기준 반영률: $100 \%$

\begin{tabular}{|c|c|c|c|c|c|c|c|c|c|}
\hline \multirow{2}{*}{ 인권기준명 } & \multirow{2}{*}{ 세부주제 } & \multicolumn{8}{|c|}{ SDG1 세부목표(targets) } \\
\hline & & 1.1 & 1.2 & 1.3 & 1.4 & 1.5 & 1.a & 1.b & 합계 \\
\hline ACHPR & 인권(기본권) & 2 & 4 & - & 4 & 4 & 3 & 12 & 29 \\
\hline $\begin{array}{l}\text { ACHPR Protocol on } \\
\text { Women's Rights }\end{array}$ & 인권(여성) & 30 & 30 & 6 & 60 & 8 & - & 78 & 212 \\
\hline $\mathrm{ACHR}$ & 인권(인권) & 2 & 4 & - & 12 & 2 & 3 & 18 & 41 \\
\hline ACRWC & 인권(아동권리) & 12 & 12 & 8 & 46 & 4 & - & 24 & 106 \\
\hline ADRDM & 인권(인권과 의무) & 4 & 4 & 2 & 6 & 2 & - & 6 & 24 \\
\hline CBD & 환경(생물다양성) & - & - & - & 10 & - & - & - & 10 \\
\hline CEDAW & 인권(여성) & 4 & 4 & 6 & 24 & - & - & 12 & 50 \\
\hline $\begin{array}{l}\text { Convention of Belém } \\
\text { do Pará }\end{array}$ & 인권(여성) & - & - & - & - & 4 & - & - & 4 \\
\hline CRC & 인권(아동) & & & 8 & 18 & & 3 & 6 & 35 \\
\hline CRPD & 인권(장애) & 4 & 4 & 2 & 32 & 4 & 9 & 18 & 73 \\
\hline DEVAW & 인권(여성폭력) & - & - & - & - & 2 & - & - & 2 \\
\hline ECHR Protc & 인권(기본권) & - & - & - & 2 & - & - & - & 2 \\
\hline $\begin{array}{l}\text { Framework Convention } \\
\text { on Minorities }\end{array}$ & 인권(소수민족) & - & - & - & 2 & - & 9 & 24 & 35 \\
\hline CCPR & 인권(정치권) & - & - & - & 2 & 2 & - & - & 4 \\
\hline ICERD & 인권(인종차별) & 2 & 2 & - & 10 & - & - & 12 & 26 \\
\hline ICESCR & 인권(사회권) & 8 & 4 & 2 & 16 & 2 & 15 & 30 & 77 \\
\hline ICRMW & 인권(이주노동자) & - & - & 6 & 8 & 7 & - & - & 16 \\
\hline ILO 102 & 노동(노동최저기준) & - & - & 2 & - & - & - & - & 2 \\
\hline ILO 118 & 노동(균등대우) & - & - & 2 & - & - & - & - & 2 \\
\hline ILO 157 & 노동(사회보장권) & - & - & 2 & - & - & - & - & 2 \\
\hline ILO Rec 202 & 노동(사회적보장) & - & - & 2 & - & - & - & - & 2 \\
\hline IACDPD & 인권(장애인) & 8 & 12 & 6 & 18 & 12 & 15 & 30 & 101 \\
\hline Paris Agreement & 환경(기후변화) & - & 8 & - & - & 48 & - & - & 56 \\
\hline $\begin{array}{l}\text { Protocol of San } \\
\text { Salvador }\end{array}$ & 인권(사회권) & 12 & 12 & 8 & 56 & 4 & 9 & 18 & 119 \\
\hline UDHR & 인권 & 2 & 2 & 2 & 4 & 2 & & 6 & 18 \\
\hline $\begin{array}{l}\text { UN Convention to } \\
\text { Combat Desertification }\end{array}$ & 환경(생물다양성) & - & - & - & 24 & 64 & - & - & 88 \\
\hline UNDRIP & 인권(원주민) & 4 & 4 & 2 & 12 & - & 3 & 6 & 31 \\
\hline UNFCCC & 환경(기후변화) & - & - & - & - & 12 & - & - & 12 \\
\hline 합계 & & 94 & 106 & 66 & 366 & 178 & 69 & 300 & 1,179 \\
\hline
\end{tabular}

17) 각 SDGs 세부목표별로 연결된 인권기준의 해당 세부 조항 및 내용은 다음에서 확인가능하다. http://sdg.humanrights.dk/ (접속일: 2018.05.10.) 또한 [붙임1]은 일괄 덴마크인권사무소 'SDGs-Human Rights Database'(http://sdg. humanrights.dk/)를 바탕으로 작성하였음을 밝힌다. 
- SDG2: 기아종식, 식량안보와 영양상태 개선 달성 및 지속가능한 농업 증진

- SDG2 세부목표 중 인권기준 반영률: $100 \%$

\begin{tabular}{|c|c|c|c|c|c|c|c|c|c|c|}
\hline \multirow{2}{*}{ 인권기준명 } & \multirow{2}{*}{ 세부주제 } & \multicolumn{9}{|c|}{ SDG2 세부목표(targets) } \\
\hline & & 2.1 & 2.2 & 2.3 & 2.4 & 2.5 & 2.a & 2.b & 2.c & 합계 \\
\hline ACHPR & 인권(기본권) & - & - & 2 & 2 & - & 3 & 6 & 6 & 19 \\
\hline $\begin{array}{l}\text { ACHPR Protocol on } \\
\text { Women's Rights }\end{array}$ & 인권(기본권) & 6 & 20 & 26 & 10 & 4 & - & 6 & - & 72 \\
\hline $\mathrm{ACHR}$ & 인권(인권) & 4 & 4 & 6 & 2 & 2 & 3 & - & - & 21 \\
\hline ACRWC & 인권(아동권리) & 12 & 16 & - & - & - & - & - & - & 28 \\
\hline ADRDM & 인권(인권과 의무) & 2 & 2 & 2 & - & - & - & - & - & 6 \\
\hline CBD & 환경(생물다양성) & - & - & 26 & 6 & 60 & 36 & 9 & - & 137 \\
\hline CEDAW & 인권(여성) & - & 2 & - & - & - & - & - & - & 2 \\
\hline $\mathrm{CRC}$ & 인권(아동) & 2 & 4 & - & - & - & - & - & - & 6 \\
\hline CRPD & 인권(장애) & 2 & 2 & - & - & - & - & - & - & 4 \\
\hline ECHR Protocol & 인권(기본권) & - & - & 2 & - & - & - & - & - & 2 \\
\hline $\begin{array}{l}\text { Framework Convention } \\
\text { on Minorities }\end{array}$ & 인권(소수민족) & - & - & 2 & - & - & - & - & - & 2 \\
\hline ICESCR & 인권(사회권) & 4 & 4 & 2 & 2 & - & 6 & 3 & 3 & 24 \\
\hline IACDPD & 인권(장애인) & - & - & 6 & - & - & - & - & - & 6 \\
\hline Paris Agreement & 환경(기후변화) & - & - & - & 26 & - & - & - & - & 26 \\
\hline $\begin{array}{l}\text { Protocol of San } \\
\text { Salvador }\end{array}$ & 인권(사회권) & 12 & 16 & 2 & 4 & - & 3 & 3 & 3 & 43 \\
\hline Ramsar convention & 환경(생물다양성) & - & - & - & 2 & - & - & - & - & 2 \\
\hline $\begin{array}{l}\text { UN Convention to } \\
\text { Combat Desertification }\end{array}$ & 환경(생물다양성) & 10 & 10 & 16 & 20 & 12 & 36 & 6 & 6 & 116 \\
\hline UNDRIP & 인권(원주민) & - & - & 4 & 2 & 2 & - & - & - & 8 \\
\hline UNFCCC & 환경(기후변화) & 2 & - & - & 4 & & - & - & - & 6 \\
\hline 합계 & & 56 & 80 & 96 & 80 & 80 & 87 & 33 & 18 & 530 \\
\hline
\end{tabular}


- SDG3: 모두를 위한 전 연령층의 건강한 삶 보장과 웰빙증진

- SDG3 세부목표 중 인권기준 반영률: $100 \%$

\begin{tabular}{|c|c|c|c|c|c|c|c|c|c|c|c|c|c|c|c|}
\hline \multirow[b]{2}{*}{ 인권기준명 } & \multirow[b]{2}{*}{ 세부주제 } & \multicolumn{14}{|c|}{ SDG3 세부목표(targets) } \\
\hline & & 3.1 & 3.23 & 3.3 & 3.4 & 3.53 & 3.6 & 3.7 & 3.83 & 3.9 & 3.a 3 & $3 . b 3$ & 3.c 3 & 3.d & $\begin{array}{l}\text { 합 } \\
\text { 계 }\end{array}$ \\
\hline ACHPR & 인권(기본권) & 8 & 6 & 6 & 6 & - & 2 & 6 & 4 & 6 & 6 & 3 & 6 & 6 & 65 \\
\hline $\begin{array}{l}\text { ACHPR Protocol on } \\
\text { Women's Rights }\end{array}$ & 인권(기본권) & 22 & - & 6 & 4 & - & - & 22 & 8 & 8 & - & - & - & - & 70 \\
\hline $\mathrm{ACHR}$ & 인권(인권) & 4 & 4 & 2 & 2 & - & 2 & - & - & 2 & - & 3 & 3 & 6 & 28 \\
\hline ACRWC & 인권(아동권리) & 8 & 8 & 2 & 12 & 2 & - & 6 & 18 & 8 & - & - & 12 & - & 76 \\
\hline ADRDM & 인권(인권과 의무) & 6 & 6 & 4 & 4 & - & 2 & 2 & 2 & 4 & - & 3 & - & - & 33 \\
\hline Basel Convention & 환경(환경) & - & - & - & - & - & - & - & - & 18 & - & - & - & - & 18 \\
\hline CEDAW & 인권(여성) & 4 & - & - & - & - & - & 6 & - & - & - & - & - & - & 10 \\
\hline $\begin{array}{l}\text { Convention of Belém do } \\
\text { Pará }\end{array}$ & 인권(여성) & 4 & - & 4 & 4 & - & - & 6 & - & 4 & - & - & - & 6 & 28 \\
\hline $\mathrm{CRC}$ & 인권(아동) & - & 16 & 16 & 16 & 2 & - & 8 & 14 & - & - & - & 3 & & 75 \\
\hline CRPD & 인권(장애) & 4 & 6 & 6 & 6 & - & 2 & 2 & 10 & 2 & - & - & 3 & 6 & 47 \\
\hline DEVAW & 인권(여성폭력) & 2 & 2 & 2 & 2 & - & 2 & - & - & 2 & - & - & - & 3 & 15 \\
\hline FCTC & 인권(담배규제) & 2 & - & - & - & - & - & - & - & - & 3 & - & - & - & 5 \\
\hline $\begin{array}{l}\text { Framework Convention } \\
\text { on Minorities }\end{array}$ & 인권(소수민족) & - & - & - & - & - & - & - & 2 & - & - & - & - & - & 2 \\
\hline ICCPR & 인권(정치권) & 2 & 2 & 2 & 2 & - & 2 & - & - & 4 & - & - & - & 24 & 38 \\
\hline ICESCR & 인권(사회권) & 10 & 10 & 10 & 10 & 2 & - & 6 & 12 & 4 & 6 & 18 & 6 & 151 & 109 \\
\hline ICRMW & 인권(이주노동자) & 6 & 4 & 4 & 4 & - & 2 & - & 4 & 2 & - & - & - & 3 & 29 \\
\hline IACDPD & 인권(장애인) & 12 & - & - & 8 & - & - & 6 & 14 & - & - & 9 & - & - & 49 \\
\hline Protocol of San Salvador & 인권(사회권) & 18 & 18 & 16 & 14 & - & - & 12 & 12 & 16 & 3 & 6 & - & -1 & 115 \\
\hline UDHR & 인권 & 4 & 4 & 4 & 4 & - & 2 & 2 & 2 & 4 & - & 6 & - & 15 & 47 \\
\hline UNDRIP & 인권(원주민) & 6 & 6 & 6 & 6 & - & 2 & - & 4 & 6 & - & - & - & 3 & 39 \\
\hline 합계 & & 122 & 92 & 901 & 104 & 6 & 18 & 84 & 106 & 90 & 18 & 48 & 33 & & 898 \\
\hline
\end{tabular}


- SDG4: 포용적이고 공평한 양질의 교육 보장 및 모두를 위한 평생학습 기회 증진

- SDG4 세부목표 중 인권기준 반영률: $100 \%$

\begin{tabular}{|c|c|c|c|c|c|c|c|c|c|c|c|c|}
\hline \multirow{2}{*}{ 인권기준명 } & \multirow{2}{*}{ 세부주제 } & \multicolumn{11}{|c|}{ SDG4 세부목표(targets) } \\
\hline & & 4.1 & 4.2 & 4.3 & 4.4 & 4.5 & 4.6 & 4.7 & 4.a & 4.b & 4.c & 합계 \\
\hline ACHPR & 인권(기본권) & 2 & 4 & 4 & 2 & 6 & 4 & 6 & 9 & - & - & 37 \\
\hline $\begin{array}{l}\text { ACHPR Proto } \\
\text { Women's Rigl }\end{array}$ & 인권(기본권) & 20 & - & 14 & 18 & 32 & 4 & 10 & 18 & - & - & 116 \\
\hline $\mathrm{ACHR}$ & 인권(인권) & 2 & 2 & 2 & 2 & 4 & 2 & - & 3 & - & - & 17 \\
\hline ACRWC & 인권(아동권리) & 22 & 8 & 6 & 8 & 16 & 4 & 10 & 15 & - & - & 89 \\
\hline ADRDM & 인권(인권과 의무) & 2 & 2 & 2 & 2 & 4 & 2 & - & 3 & - & - & 17 \\
\hline CBD & 환경(생물다양성) & - & - & - & - & - & - & 6 & - & - & - & 6 \\
\hline CEDAW & 인권(여성) & 16 & 16 & 4 & 4 & 16 & 4 & 4 & - & 6 & - & 70 \\
\hline $\mathrm{CRC}$ & 인권(아동) & 24 & 24 & 4 & 4 & 14 & & 12 & - & 3 & - & 85 \\
\hline CRPD & 인권(장애) & 16 & 16 & 2 & 2 & 16 & 18 & 6 & 6 & - & 3 & 85 \\
\hline ECHR Protocol & 인권(기본권) & 2 & 2 & 2 & & 2 & 2 & 2 & 3 & - & - & 15 \\
\hline $\begin{array}{l}\text { Framework Conv } \\
\text { on Minorities }\end{array}$ & 인권(소수민족) & 18 & - & 10 & 2 & 12 & 16 & 6 & - & - & 9 & 73 \\
\hline ICCPR & 인권(정치권) & - & - & - & - & - & - & 2 & - & - & - & 2 \\
\hline ICERD & 인권(인종차별) & - & - & - & - & - & - & 2 & - & - & - & 2 \\
\hline ICESCR & 인권(사회권) & 12 & 12 & 6 & 6 & 18 & 6 & 2 & 3 & 3 & 3 & 71 \\
\hline ICRMW & 인권(이주노동자) & 2 & 2 & 8 & 8 & 10 & - & - & - & - & - & 30 \\
\hline ILO 142 & 노동(인적자원) & - & - & 2 & 2 & 2 & - & - & - & - & - & 6 \\
\hline ILO 159 & 노동(장애인 고용) & - & - & 2 & 2 & 2 & - & - & - & - & - & 6 \\
\hline ILO 169 & $\begin{array}{l}\text { 노동(토착민, } \\
\text { 부족민) }\end{array}$ & - & - & - & - & 12 & - & - & - & - & - & 12 \\
\hline IACDPD & 인권(장애인) & 18 & - & 10 & 6 & 16 & 16 & 14 & 12 & - & - & 92 \\
\hline Paris Agreement & 환경(기후변화) & - & - & - & - & - & - & 6 & - & - & - & 6 \\
\hline Protocol of San Salvador & 인권(사회권) & 16 & 2 & 12 & 4 & 20 & 8 & 2 & 3 & - & - & 67 \\
\hline UDHR & 인권 & 4 & 4 & 4 & 4 & 2 & 2 & 2 & - & - & - & 22 \\
\hline $\begin{array}{l}\text { UN Convention to } \\
\text { Combat Desertification }\end{array}$ & 환경(생물다양성) & - & - & - & - & - & - & 40 & - & - & - & 40 \\
\hline UNDRIP & 인권(원주민) & 8 & 8 & 2 & 2 & 6 & - & 2 & - & - & - & 28 \\
\hline UNFCCC & 환경(기후변화) & - & - & - & - & - & - & 18 & - & - & - & 18 \\
\hline 법세 & & 184 & 102 & 96 & 78 & 210 & 88 & 152 & 75 & 12 & 15 & 1012 \\
\hline
\end{tabular}


- SDG5: 성평등 달성과 모든 여성 및 여아의 역량 강화

- SDG5 세부목표 중 인권기준 반영률: $100 \%$

\begin{tabular}{|c|c|c|c|c|c|c|c|c|c|c|c|}
\hline \multirow{2}{*}{ 국제인권기준 } & \multirow{2}{*}{ 세부주제 } & \multicolumn{10}{|c|}{ SDG5 세부목표(targets) } \\
\hline & & 5.1 & 5.2 & 5.3 & 5.4 & 5.5 & 5.6 & $5 . a$ & 5.b & 5.c & 합계 \\
\hline ACHPR & 인권(기본권) & 4 & 6 & 6 & 4 & 6 & 6 & 6 & 9 & 6 & 53 \\
\hline $\begin{array}{l}\text { ACHPR Protocol on } \\
\text { Women's Rights }\end{array}$ & 인권(기본권) & 6 & 26 & 30 & 6 & 30 & 22 & 24 & 6 & 18 & 168 \\
\hline $\mathrm{ACHR}$ & 인권(인권) & 4 & 4 & 4 & 2 & 10 & 2 & 15 & 3 & 9 & 53 \\
\hline ACRWC & 인권(아동권리) & 4 & 24 & 12 & 6 & - & 8 & - & - & - & 54 \\
\hline ADRDM & 인권(인권과 의무) & 2 & 4 & 6 & 4 & 4 & 4 & 6 & 6 & 3 & 39 \\
\hline CBD & 환경(생물다양성) & - & - & - & - & - & - & 18 & - & - & 18 \\
\hline CEDAW & 인권(여성) & 20 & - & 2 & 2 & 4 & 10 & 15 & 3 & 12 & 68 \\
\hline $\begin{array}{l}\text { Convention of Belém } \\
\text { do Pará }\end{array}$ & 인권(여성) & 38 & 2 & 14 & - & - & - & - & - & 12 & 66 \\
\hline CRC & 인권(아동) & - & 16 & 6 & - & - & 10 & - & - & - & 32 \\
\hline CRPD & 인권(장애) & - & 6 & - & - & - & 4 & - & 21 & - & 31 \\
\hline DEVAW & 인권(여성폭력) & 2 & 2 & 6 & - & - & & - & - & - & 10 \\
\hline ECHR & 인권(기본권) & 2 & 2 & 2 & - & - & 4 & - & 3 & - & 13 \\
\hline ECHR Protocol & 인권(기본권) & - & - & - & - & 2 & - & 3 & - & - & 5 \\
\hline $\begin{array}{l}\text { Framework } \\
\text { Convention on } \\
\text { Minorities }\end{array}$ & 인권(소수민족) & - & - & - & - & 2 & - & - & 3 & - & 5 \\
\hline ICCPR & 인권(정치권) & 2 & 2 & 2 & - & 4 & 6 & - & 6 & - & 22 \\
\hline ICERD & 인권(인종차별) & - & - & 2 & - & 2 & - & 6 & - & - & 10 \\
\hline ICESCR & 인권(사회권) & 4 & 2 & 4 & 10 & 2 & 6 & 3 & 6 & 6 & 43 \\
\hline ICRMW & 인권(이주노동자) & - & 6 & - & - & - & 4 & - & - & - & 10 \\
\hline ILO 156 & 노동(가족부양) & - & - & - & 2 & - & - & - & - & - & 2 \\
\hline IACDPD & 인권(장애인) & - & - & - & - & - & - & - & 9 & - & 9 \\
\hline $\begin{array}{l}\text { Protocol of San } \\
\text { Salvador }\end{array}$ & 인권(사회권) & 6 & 8 & 6 & 2 & - & 22 & 3 & 3 & 6 & 56 \\
\hline UDHR & 인권 & 2 & 2 & 6 & - & 2 & - & 3 & 6 & - & 21 \\
\hline $\begin{array}{l}\text { UN Convention to } \\
\text { Combat Desertification }\end{array}$ & 환경(생물다양성) & - & - & - & - & 12 & - & 18 & - & - & 30 \\
\hline UNDRIP & 인권(원주민) & 2 & 2 & 2 & - & - & - & - & - & - & 6 \\
\hline 합계 & & 98 & 114 & 110 & 38 & 80 & 108 & 120 & 84 & 72 & 824 \\
\hline
\end{tabular}


- SDG6: 모두를 위한 물과 위생설비의 이용가능성과 지속가능한 유지관리 보장

- SDG6 세부목표 중 인권기준 반영률: $100 \%$

\begin{tabular}{|c|c|c|c|c|c|c|c|c|c|c|}
\hline \multirow{2}{*}{ 국제인권기준 } & \multirow{2}{*}{ 세부주제 } & \multicolumn{9}{|c|}{ SDG6 세부목표(targets) } \\
\hline & & 6.1 & 6.2 & 6.3 & 6.4 & 6.5 & 6.6 & $6 . a$ & $6 . b$ & 합계 \\
\hline ACHPR & 인권(기본권) & 4 & 6 & 6 & 8 & - & 2 & - & - & 26 \\
\hline $\begin{array}{l}\text { ACHPR Protocol on } \\
\text { Women's Rights }\end{array}$ & 인권(기본권) & 4 & 6 & 8 & 4 & - & - & - & 12 & 34 \\
\hline ACRWC & 인권(아동권리) & 4 & 6 & 4 & 4 & - & - & - & 6 & 24 \\
\hline ADRDM & 인권(인권과 의무) & - & 2 & 2 & - & - & - & - & - & 4 \\
\hline Basel Convention & 환경(환경) & - & - & 40 & - & - & - & - & - & 40 \\
\hline $\mathrm{CBD}$ & 환경(생물다양성) & - & - & - & - & - & 60 & - & - & 60 \\
\hline CEDAW & 인권(여성) & 2 & 2 & - & 2 & 2 & - & - & - & 8 \\
\hline $\mathrm{CRC}$ & 인권(아동) & 2 & 2 & - & 2 & 2 & - & 6 & - & 14 \\
\hline CRPD & 인권(장애) & 2 & 2 & - & 2 & 2 & - & 6 & - & 14 \\
\hline $\begin{array}{l}\text { Framework Convention } \\
\text { on Minorities }\end{array}$ & 인권(소수민족) & 2 & 2 & - & - & - & - & - & 3 & 7 \\
\hline ICCPR & 인권(정치권) & - & - & - & - & - & - & - & 3 & 3 \\
\hline ICESCR & 인권(사회권) & 6 & 6 & 4 & 6 & 6 & - & 18 & & 46 \\
\hline ILO 169 & $\begin{array}{l}\text { 노동(토착민, } \\
\text { 부족민) }\end{array}$ & - & - & - & - & - & - & - & 18 & 18 \\
\hline IACDPD & 인권(장애인) & - & - & - & 4 & - & - & - & - & 4 \\
\hline $\begin{array}{l}\text { Protocol of San } \\
\text { Salvador }\end{array}$ & 인권(사회권) & 4 & 8 & 6 & 6 & 2 & 2 & - & - & 28 \\
\hline Ramsar convention & 환경(생물다양성) & - & - & - & 2 & 4 & 10 & - & - & 16 \\
\hline UDHR & 인권 & 2 & 2 & & 2 & 2 & - & 6 & - & 14 \\
\hline $\begin{array}{l}\text { UN Convention on } \\
\text { the Law of the Sea }\end{array}$ & 환경(환경) & - & - & 78 & - & - & 40 & 33 & - & 151 \\
\hline $\begin{array}{l}\text { UN Convention to } \\
\text { Combat Desertification }\end{array}$ & 환경(생물다양성) & 8 & - & - & 12 & 4 & 2 & - & 18 & 44 \\
\hline UNDRIP & 인권(원주민) & - & - & 2 & - & 2 & 2 & 3 & 9 & 18 \\
\hline \multicolumn{2}{|l|}{ 합계 } & 40 & 44 & 150 & 54 & 26 & 118 & 72 & 69 & 573 \\
\hline
\end{tabular}


- SDG7: 모두를 위한 적정가격의 신뢰할 수 있고 지속가능하며 현대적인 에너지에 대한 접근 보장

- SDG7 세부목표 중 인권기준 반영률: $100 \%$

\begin{tabular}{|c|c|c|c|c|c|c|c|}
\hline \multirow{2}{*}{ 국제인권기준 } & \multirow{2}{*}{ 세부주제 } & \multicolumn{6}{|c|}{ SDG7 세부목표(targets) } \\
\hline & & 7.1 & 7.2 & 7.3 & 7.a & 7.b & 합계 \\
\hline ACHPR & 인권(기본권) & 4 & 2 & - & - & 3 & 9 \\
\hline $\begin{array}{l}\text { ACHPR Protocol on } \\
\text { Women's Rights }\end{array}$ & 인권(기본권) & 4 & 4 & 4 & - & - & 12 \\
\hline CEDAW & 인권(여성) & 4 & - & - & - & 6 & 10 \\
\hline CRPD & 인권(장애) & 2 & - & - & - & 3 & 5 \\
\hline ICERD & 인권(인종차별) & 2 & - & - & - & 3 & 5 \\
\hline ICESCR & 인권(사회권) & 2 & - & - & 18 & 3 & 23 \\
\hline IACDPD & 인권(장애인) & 6 & - & - & - & - & 6 \\
\hline Paris Agreement & 환경(기후변화) & - & - & - & 21 & - & 21 \\
\hline $\begin{array}{l}\text { Protocol of San } \\
\text { Salvador }\end{array}$ & 인권(사회권) & - & - & - & 3 & - & 3 \\
\hline UDHR & 인권 & 2 & - & - & 6 & 3 & 11 \\
\hline $\begin{array}{l}\text { UN Convention to } \\
\text { Combat Desertification }\end{array}$ & 환경(생물다양성) & - & 4 & - & - & - & 4 \\
\hline UNDRIP & 인권(원주민) & 4 & - & - & - & 6 & 10 \\
\hline UNFCCC & 환경(기후변화) & - & - & - & 9 & - & 9 \\
\hline \multicolumn{2}{|c|}{ 합계 } & 30 & 10 & 4 & 57 & 27 & 128 \\
\hline
\end{tabular}


- SDG8: 모두를 위한 지속적, 포용적인 경제성장, 완전하고 생산적인 고용과 양질의 일자리 증진

- SDG8 세부목표 중 인권기준 반영률: $91.7 \%$ (미반영 세부목표: 8.1)

\begin{tabular}{|c|c|c|c|c|c|c|c|c|c|c|c|c|c|}
\hline \multirow{2}{*}{ 국제인권기준 } & \multirow{2}{*}{ 세부주제 } & \multicolumn{12}{|c|}{ SDG8 세부목표(targets) } \\
\hline & & 8.2 & 8.3 & 8.4 & 8.5 & 8.6 & 8.7 & 8.8 & 8.9 & 8.10 & $8 . a$ & $8 . b$ & 합계 \\
\hline ACHPR & 인권(기본권) & 2 & 2 & 8 & 8 & 10 & 12 & 14 & - & - & - & - & 56 \\
\hline $\begin{array}{l}\text { ACHPR Protocol on } \\
\text { Women's Rights }\end{array}$ & 인권(기본권) & 6 & 14 & 14 & 36 & 34 & 24 & 42 & - & 4 & - & - & 174 \\
\hline $\mathrm{ACHR}$ & 인권(인권) & 2 & 2 & 2 & 8 & 2 & 22 & 10 & 2 & 2 & - & - & 52 \\
\hline ACRWC & 인권(아동권리) & - & - & - & 20 & 18 & 26 & 10 & - & - & - & - & 74 \\
\hline ADRDM & 인권(인권과 의무) & 2 & - & - & 8 & 6 & 2 & 8 & - & - & - & - & 26 \\
\hline Basel Conv & 환경(환경) & - & - & - & - & - & - & 6 & - & - & - & - & 6 \\
\hline CBD & 환경(생물다양성) & - & - & 18 & - & - & - & - & - & - & - & - & 18 \\
\hline CEDAW & 인권(여성) & - & 2 & 12 & 12 & 14 & 2 & 4 & - & 6 & & 18 & 70 \\
\hline $\begin{array}{l}\text { Convention of Belém } \\
\text { do Pará }\end{array}$ & 인권(여성) & - & - & - & - & - & 6 & 2 & - & - & - & - & 8 \\
\hline $\mathrm{CRC}$ & 인권(아동) & - & - & - & - & - & 20 & & - & - & - & - & 20 \\
\hline CRPD & 인권(장애) & - & - & 18 & 24 & 24 & 4 & 2 & - & - & - & 33 & 105 \\
\hline $\mathrm{ECHR}$ & 인권(기본권) & - & - & - & - & - & 4 & 4 & - & - & - & - & 8 \\
\hline ECHR Protocol No. 4 & 인권(기본권) & - & - & - & - & - & 2 & & - & - & - & - & 2 \\
\hline $\begin{array}{l}\text { Framework Convention } \\
\text { on Minorities }\end{array}$ & 인권(소수민족) & - & 2 & - & 8 & 2 & 2 & 2 & - & - & - & - & 16 \\
\hline ICCPR & 인권(정치권) & - & - & - & - & - & 6 & - & - & - & - & - & 6 \\
\hline ICERD & 인권(인종차별) & - & - & 2 & 2 & 2 & - & - & - & - & - & 3 & 9 \\
\hline ICESCR & 인권(사회권) & 8 & - & 14 & 14 & 16 & 6 & 8 & - & - & 18 & 6 & 90 \\
\hline ICRMW & 인권(이주노동자) & - & - & 2 & 2 & 6 & 4 & 2 & - & - & - & - & 16 \\
\hline ILO 100 & 노동(동등보수) & - & - & 2 & 2 & 2 & - & 2 & - & - & - & - & 8 \\
\hline ILO 105 & 노동(강제근로) & - & - & - & - & - & 2 & 2 & - & - & - & - & 4 \\
\hline ILO 111 & 노동(고용차별) & - & - & 2 & 2 & 2 & - & 2 & - & - & - & - & 8 \\
\hline ILO 122 & 노동(고용정책) & - & - & 2 & 2 & 2 & - & 2 & - & - & - & 3 & 11 \\
\hline ILO 129 & 노동(근로감사농업) & - & - & - & - & - & - & 2 & - & - & - & - & 2 \\
\hline ILO 131 & 노동(최저임금) & - & - & 2 & 2 & 2 & - & - & - & - & - & - & 6 \\
\hline ILO 138 & 노동(노동최저연령) & - & - & - & - & - & 2 & 2 & - & - & - & - & 4 \\
\hline ILO 142 & 노동(인적자원) & - & - & 2 & 2 & 2 & - & - & - & - & - & 3 & 9 \\
\hline ILO 144 & 노동(삼자협의) & - & - & - & - & - & - & 2 & - & - & - & - & 2 \\
\hline ILO 155 & 노동(산업안전) & - & - & - & - & - & - & 2 & - & - & - & - & 2 \\
\hline ILO 159 & 노동(장애인 고용) & - & - & 2 & 2 & 2 & - & - & - & - & - & 3 & 9 \\
\hline ILO 161 & 노동(산업보건) & - & - & - & - & - & - & 2 & - & - & - & - & 2 \\
\hline
\end{tabular}

제 I 장

\section{제II장}

섹 


\begin{tabular}{|c|c|c|c|c|c|c|c|c|c|c|c|c|c|}
\hline \multirow{2}{*}{ 국제인권기준 } & \multirow{2}{*}{ 세부주제 } & \multicolumn{12}{|c|}{ SDG8 세부목표(targets) } \\
\hline & & 8.2 & 8.3 & 8.4 & 8.5 & 8.6 & 8.7 & 8.8 & 8.9 & 8.10 & $8 . a$ & $8 . b$ & 합계 \\
\hline ILO 172 & $\begin{array}{l}\text { 노동(근로조건- } \\
\text { 호텔, 식당) }\end{array}$ & - & - & - & - & - & - & - & 2 & - & - & - & 2 \\
\hline ILO 181 & 노동(직업소개소) & - & - & 2 & 2 & 2 & - & - & - & - & - & 3 & 9 \\
\hline ILO 182 & 노동(아동노동) & - & - & - & - & - & 2 & 2 & - & - & - & - & 4 \\
\hline ILO 187 & 노동(산업안전) & - & - & - & - & - & & 2 & - & - & - & - & 2 \\
\hline ILO 29 & 노동(강제근로) & - & - & - & - & - & 2 & 2 & - & - & - & - & 4 \\
\hline ILO 81 & 노동(근로감독) & - & - & - & - & - & - & 2 & - & - & - & - & 2 \\
\hline ILO 87 & 노동(결사 및 단결권) & - & - & - & - & - & - & 2 & - & - & - & - & 2 \\
\hline ILO 94 & 노동(노동조항) & - & - & 2 & 2 & 2 & - & - & - & - & - & - & 6 \\
\hline ILO 95 & 노동(임금보호) & - & - & 2 & 2 & 2 & - & - & - & - & - & - & 6 \\
\hline ILO 98 & 노동(단체교섭) & - & - & - & - & - & - & 2 & - & - & - & - & 2 \\
\hline ILO Protocol 29 & 노동(강제근로) & - & - & - & - & - & 2 & 2 & - & - & - & - & 4 \\
\hline ILO Rec 189 & 노동(중소기업) & - & - & - & - & - & - & - & 2 & - & - & - & 2 \\
\hline ILO Rec 203 & 노동(강제근로) & - & - & - & - & - & 2 & - & - & - & - & - & 2 \\
\hline IACDPD & 인권(장애인) & - & 12 & 8 & 12 & 12 & - & 14 & - & - & - & 18 & 76 \\
\hline Paris Agreement & 환경(기후변화) & - & - & 16 & - & - & - & - & - & - & - & - & 16 \\
\hline $\begin{array}{l}\text { Protocol of San } \\
\text { Salvador }\end{array}$ & 인권(사회권) & 8 & - & 18 & 26 & 18 & 8 & 12 & - & - & 12 & 6 & 108 \\
\hline UDHR & 인권 & 6 & - & 6 & 6 & 8 & 2 & 8 & - & - & 9 & 3 & 48 \\
\hline $\begin{array}{l}\text { UN Convention on the } \\
\text { Law of the Sea }\end{array}$ & 환경(환경) & - & - & 10 & - & - & - & - & - & - & - & - & 10 \\
\hline $\begin{array}{l}\text { UN Convention to } \\
\text { Combat Desertification }\end{array}$ & 환경(생물다양성) & - & - & 4 & - & - & - & - & - & - & - & - & 4 \\
\hline UNDRIP & 인권(원주민) & - & - & 2 & 2 & 2 & 2 & - & 8 & - & - & - & 16 \\
\hline UNFCCC & 환경(기후변화) & - & - & 6 & - & - & - & - & - & - & - & - & 6 \\
\hline \multicolumn{2}{|l|}{ 합계 } & 34 & 34 & 178 & 206 & 192 & 166 & 180 & 14 & 12 & 39 & 99 & 1,154 \\
\hline
\end{tabular}


- SDG9: 회복력있는 사회기반시설 구축, 포용적이고 지속가능한 산업화 증진 및 혁신 장려

- SDG9 세부목표 중 인권기준 반영률: $100 \%$

\begin{tabular}{|c|c|c|c|c|c|c|c|c|c|c|}
\hline \multirow{2}{*}{ 국제인권기준 } & \multirow{2}{*}{ 세부주제 } & \multicolumn{9}{|c|}{ SDG9 세부목표(targets) } \\
\hline & & 9.1 & 9.2 & 9.3 & 9.4 & 9.5 & $9 . a$ & $9 . \mathrm{b}$ & 9.c & 합계 \\
\hline ACHPR & 인권(기본권) & - & - & - & - & - & - & - & 6 & 6 \\
\hline $\begin{array}{l}\text { ACHPR Protocol on } \\
\text { Women's Rights }\end{array}$ & 인권(기본권) & 4 & - & 4 & - & - & - & - & - & 8 \\
\hline $\mathrm{ACHR}$ & 인권(인권) & - & 2 & 2 & 2 & 2 & - & 3 & 6 & 17 \\
\hline ACRWC & 인권(아동권리) & 2 & - & - & - & - & - & - & - & 2 \\
\hline ADRDM & $\begin{array}{c}\text { 인권 } \\
\text { (인권과 의무) }\end{array}$ & - & - & - & 2 & 2 & - & - & 3 & 7 \\
\hline CBD & $\begin{array}{c}\text { 환경 } \\
\text { (생물다양성) }\end{array}$ & 12 & 6 & - & 6 & - & - & - & - & 24 \\
\hline CEDAW & 인권(여성) & 2 & - & 2 & - & - & - & - & 3 & 7 \\
\hline CRC & 인권(아동) & - & - & - & & 2 & 3 & - & - & 5 \\
\hline CRPD & 인권(장애) & 2 & - & - & 2 & 2 & 3 & 3 & 15 & 27 \\
\hline ECHR & 인권(기본권) & - & - & - & - & - & - & - & 3 & 3 \\
\hline $\begin{array}{l}\text { Framework Convention } \\
\text { on Minorities }\end{array}$ & 인권(소수민족) & 2 & - & - & - & - & - & - & 3 & 5 \\
\hline ICCPR & 인권(정치권) & - & - & - & - & - & - & - & 3 & 3 \\
\hline ICESCR & 인권(사회권) & 2 & - & - & 4 & 12 & 18 & 6 & 3 & 45 \\
\hline ILO Rec 189 & 노동(중소기업) & - & - & 2 & - & - & - & - & - & 2 \\
\hline IACDPD & 인권(장애인) & 8 & - & - & - & - & - & - & - & 8 \\
\hline Paris Agreement & 환경(기후변화) & - & - & - & 10 & - & - & - & - & 10 \\
\hline $\begin{array}{l}\text { Protocol of San } \\
\text { Salvador }\end{array}$ & 인권(사회권) & 4 & - & - & - & 8 & 12 & 9 & 6 & 39 \\
\hline UDHR & 인권 & 2 & - & - & 4 & 6 & 9 & 6 & 9 & 36 \\
\hline UNDRIP & 인권(원주민) & 2 & - & - & - & - & - & - & - & 2 \\
\hline UNFCCC & 환경(기후변화) & - & - & - & 6 & - & - & - & - & 6 \\
\hline 합계 & & 42 & 8 & 10 & 36 & 34 & 45 & 27 & 60 & 262 \\
\hline
\end{tabular}


- SDG10: 국내 및 국가간 불평등 감소

- SDG10: 세부목표 중 인권기준 반영률: $90 \%$ (미반영 세부목표:10.5)

\begin{tabular}{|c|c|c|c|c|c|c|c|c|c|c|c|}
\hline \multirow{2}{*}{ 국제인권기준 } & \multirow{2}{*}{ 세부주제 } & \multicolumn{10}{|c|}{ SDG10 세부목표(targets) } \\
\hline & & 10.1 & 10.2 & 10.3 & 10.4 & 10.6 & 10.7 & 10.a & 10.b & $10 . \mathrm{c}$ & 합계 \\
\hline ACHPR & 인권(기본권) & 10 & 12 & 12 & 8 & - & 16 & 3 & 3 & - & 64 \\
\hline $\begin{array}{l}\text { ACHPR Protocol on } \\
\text { Women's Rights }\end{array}$ & 인권(기본권) & 26 & 72 & 68 & 34 & - & 4 & - & - & - & 204 \\
\hline $\mathrm{ACHR}$ & 인권(인권) & 2 & 12 & 6 & 2 & - & 4 & - & - & - & 26 \\
\hline ACRWC & 인권(아동권리) & 6 & 6 & 4 & 10 & - & 22 & - & - & - & 48 \\
\hline ADRDM & $\begin{array}{c}\text { 인권 } \\
\text { (인권과 의무) }\end{array}$ & 6 & 8 & 2 & 4 & - & - & - & - & - & 20 \\
\hline CEDAW & 인권(여성) & 4 & 30 & 30 & 24 & - & 2 & - & - & - & 90 \\
\hline $\begin{array}{l}\text { Convention of Belém } \\
\text { do Pará }\end{array}$ & 인권(여성) & - & - & - & - & - & 2 & - & - & - & 2 \\
\hline CRC & 인권(아동) & 4 & 12 & 12 & 12 & - & 28 & - & - & - & 68 \\
\hline CRPD & 인권(장애) & 8 & 12 & 14 & 12 & - & 6 & - & - & - & 52 \\
\hline CTOC & 노동(조직범죄) & - & - & - & - & - & 2 & - & - & - & 2 \\
\hline DEVAW & 인권(여성폭력) & - & - & - & - & - & 2 & - & - & - & 2 \\
\hline ECHR & 인권(기본권) & - & 2 & 2 & - & - & 4 & - & - & - & 8 \\
\hline ECHR Protocol & 인권(기본권) & - & 2 & 2 & - & - & - & - & - & - & 4 \\
\hline ECHR Protocol No. 12 & 인권(기본권) & 4 & 4 & 4 & - & - & - & - & - & - & 12 \\
\hline ECHR Protocol No. 4 & 인권(기본권) & - & - & - & - & - & 8 & - & - & - & 8 \\
\hline ECHR Protocol No. 7 & 인권(기본권) & - & - & - & - & - & 10 & - & - & - & 10 \\
\hline $\begin{array}{l}\text { Framework Convention } \\
\text { on Minorities }\end{array}$ & 인권(소수민족) & 2 & 2 & 6 & 2 & - & 8 & - & - & - & 20 \\
\hline ICCPR & 인권(정치권) & 2 & 10 & 10 & - & 2 & 12 & - & - & - & 36 \\
\hline ICERD & 인권(인종차별) & 8 & 10 & 10 & 4 & - & 2 & - & - & - & 34 \\
\hline ICESCR & 인권(사회권) & 6 & 12 & 10 & 12 & 2 & 2 & 9 & 9 & - & 62 \\
\hline ICRMW & 인권(이주노동자) & 2 & 8 & 10 & 10 & - & 6 & - & - & 6 & 42 \\
\hline ILO 100 & 노동(동등보수) & - & - & - & 2 & - & - & - & - & - & 2 \\
\hline ILO 102 & $\begin{array}{c}\text { 노동 } \\
\text { (노동최저기준) }\end{array}$ & - & 2 & 2 & 2 & - & - & - & - & - & 6 \\
\hline ILO 105 & 노동(강제근로) & - & - & - & - & - & 2 & - & - & - & 2 \\
\hline ILO 111 & 노동(고용차별) & - & - & - & 2 & - & - & - & - & - & 2 \\
\hline ILO 118 & 노동(균등대우) & - & 2 & 2 & 2 & - & - & - & - & - & 6 \\
\hline ILO 131 & 노동(최저임금) & - & - & - & 2 & - & - & - & - & - & 2 \\
\hline ILO 143 & $\begin{array}{c}\text { 노동 } \\
\text { (이주근로자) }\end{array}$ & - & - & - & - & - & 2 & - & - & - & 2 \\
\hline
\end{tabular}




\begin{tabular}{|c|c|c|c|c|c|c|c|c|c|c|c|}
\hline \multirow{2}{*}{ 국제인권기준 } & \multirow{2}{*}{ Nㅔ부주제 } & \multicolumn{10}{|c|}{ SDG10 세부목표(targets) } \\
\hline & & 10.1 & 10.2 & 10.3 & 10.4 & 10.6 & 10.7 & $10 . a$ & 10.b & 10.c & 합계 \\
\hline ॥OO 157 & $\begin{array}{c}\text { 노동 } \\
\text { (사회보장권) }\end{array}$ & - & 2 & 2 & 2 & - & - & - & - & - & 6 \\
\hline ॥OO 181 & $\begin{array}{c}\text { 노동 } \\
\text { (직업소개소) }\end{array}$ & - & - & - & - & - & 2 & - & - & - & 2 \\
\hline ILO 182 & 노동(아동노동) & - & - & - & - & - & 2 & - & - & - & 2 \\
\hline ILO 29 & 노동(강제근로) & - & - & - & - & - & 2 & - & - & - & 2 \\
\hline ILO 95 & 노동(임금보호) & - & - & - & 2 & - & & - & - & - & 2 \\
\hline ॥LO 97 & 노동(취업이주) & - & - & - & - & - & 2 & - & - & - & 2 \\
\hline ILO Protocol 29 & 노동(강제근로) & - & - & - & - & - & 2 & - & - & - & 2 \\
\hline ILO Rec 151 & $\begin{array}{c}\text { 노동 } \\
\text { (이주근로자) }\end{array}$ & - & - & - & - & - & 2 & - & - & - & 2 \\
\hline ILO Rec 202 & $\begin{array}{c}\text { 노동 } \\
\text { (사회적보장) }\end{array}$ & - & 2 & 2 & 2 & - & - & - & - & - & 6 \\
\hline ILO Rec 203 & 노동(강제근로) & - & - & - & - & - & 2 & - & - & - & 2 \\
\hline ILO Rec 86 & 노동(취업이주) & - & - & - & - & - & 2 & - & - & - & 2 \\
\hline IACDPD & 인권(장애인) & 6 & 20 & 16 & 6 & - & - & - & - & - & 48 \\
\hline $\begin{array}{l}\text { Protocol of San } \\
\text { Salvador }\end{array}$ & 인권(사회권) & 6 & 14 & 10 & 12 & - & 2 & 6 & 3 & - & 53 \\
\hline UDHR & 인권 & 4 & 10 & 10 & 8 & 2 & 6 & 6 & 6 & - & 52 \\
\hline $\begin{array}{l}\text { UN Convention to } \\
\text { Combat Desertification }\end{array}$ & $\begin{array}{c}\text { 환경 } \\
\text { (생물다양성) }\end{array}$ & - & 12 & - & - & - & - & - & - & - & 12 \\
\hline UNDRIP & 인권(원주민) & 6 & 14 & 14 & 8 & - & 4 & - & - & - & 46 \\
\hline UNGP & 인권(기업인권) & - & - & - & - & - & - & - & 3 & - & 3 \\
\hline 합계 & & 112 & 292 & 260 & 184 & 6 & 172 & 24 & 24 & 6 & 1,080 \\
\hline
\end{tabular}


- SDG11: 포용적이며 안전하고 회복력있고 지속가능한 도시와 주거 보장

- SDG11 세부목표 중 인권기준 반영률: $100 \%$

\begin{tabular}{|c|c|c|c|c|c|c|c|c|c|c|c|c|}
\hline \multirow{2}{*}{ 국제인권기준 } & \multirow{2}{*}{ |부주제 } & \multicolumn{11}{|c|}{ SDG11 세부목표(targets) } \\
\hline & & 11.1 & 11.2 & 11.3 & 11.4 & 11.5 & 11.6 & 11.7 & 11.a & 11.b & 11.c & 합계 \\
\hline ACHPR & 인권(기본권) & 2 & 2 & 4 & 4 & 6 & 4 & 4 & 3 & - & - & 29 \\
\hline $\begin{array}{l}\text { ACHPR Protocol on } \\
\text { Women's Rights }\end{array}$ & 인권(기본권) & 2 & - & 14 & 6 & 6 & 10 & 14 & 3 & 3 & - & 58 \\
\hline $\mathrm{ACHR}$ & 인권( & 2 & 2 & 2 & 2 & 4 & 2 & 2 & 3 & 3 & 3 & 25 \\
\hline ACRWC & 인권(아동권리) & 2 & 2 & 4 & & 4 & 2 & 6 & - & - & - & 20 \\
\hline ADRDM & 인권(인권과 의무) & 2 & 2 & - & 2 & 2 & 2 & - & - & - & - & 10 \\
\hline Basel C & 환경(환경) & - & - & - & - & - & 20 & - & - & - & - & 20 \\
\hline CBD & 환경(생물다양성) & - & - & 4 & 128 & - & - & - & 15 & - & - & 147 \\
\hline CEDAW & 인권(여성) & 2 & 2 & 6 & - & - & - & 2 & - & - & - & 12 \\
\hline $\begin{array}{l}\text { Conventio } \\
\text { do Pará }\end{array}$ & 인권(여성) & - & - & - & - & 6 & - & - & - & - & - & 6 \\
\hline $\mathrm{CRC}$ & 인권(아동) & - & - & 2 & - & 6 & - & 2 & - & - & - & 10 \\
\hline CRPD & 인권(장애) & 4 & 8 & 2 & - & 4 & - & 10 & - & - & - & 28 \\
\hline DEVAW & 인권(여성폭력) & - & - & - & - & 2 & - & - & - & - & - & 2 \\
\hline $\begin{array}{l}\text { Framewo } \\
\text { on Minori }\end{array}$ & 인권(소수민족) & 2 & - & 2 & 28 & - & - & - & - & - & - & 32 \\
\hline ICCPR & 인권(정치권) & - & - & 4 & - & 2 & - & - & - & - & - & 6 \\
\hline ICERD & 인권(인종차별) & 2 & - & 2 & - & - & - & - & - & - & - & 4 \\
\hline ICESCR & 인권(사회권) & 2 & 4 & - & 2 & 4 & 4 & - & - & 6 & 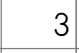 & 22 \\
\hline ICRMW & 인권(이주노동자) & 2 & - & 10 & - & 2 & - & - & - & - & - & 14 \\
\hline IACDPD & 인권(장애인) & 10 & 10 & 2 & - & - & - & 10 & - & - & - & 32 \\
\hline Paris Agre & 환경(기후변화) & - & - & - & - & 6 & 10 & - & - & 36 & - & 52 \\
\hline $\begin{array}{l}\text { Protocol o } \\
\text { Salvador }\end{array}$ & 인권(사회권) & 2 & 8 & 4 & 6 & 4 & 4 & 8 & 3 & 3 & - & 42 \\
\hline Ramsar convention & 환경(생물다양성) & - & - & - & 8 & - & - & - & - & - & - & 8 \\
\hline UDHR & 인권 & 2 & - & 2 & - & 2 & - & - & - & - & - & 6 \\
\hline $\begin{array}{l}\text { UN Convention to } \\
\text { Combat Desertification }\end{array}$ & 환경(생물다양성) & - & - & - & - & 34 & - & - & 9 & 36 & - & 79 \\
\hline UNDRIP & 인권(원주민) & 2 & - & - & 10 & 2 & 2 & - & - & - & - & 16 \\
\hline UNFCCC & 환경(기후변화) & - & - & 4 & 14 & 8 & 8 & - & 6 & 21 & - & 61 \\
\hline 합가 & & 40 & 40 & 68 & 210 & 104 & 68 & 58 & 42 & 105 & 6 & 741 \\
\hline
\end{tabular}


- SDG12: 지속가능한 생산과 소비양식 보장

- SDG12 세부목표 중 인권기준 반영률: $100 \%$

\begin{tabular}{|c|c|c|c|c|c|c|c|c|c|c|c|c|c|}
\hline \multirow{2}{*}{ 국제인권기준 } & \multirow{2}{*}{ |부주제 } & \multicolumn{12}{|c|}{ SDG12 세부목표(targets) } \\
\hline & & 12.1 & 12.2 & 12.3 & 12.4 & 12.5 & 12.6 & 12.7 & 12.8 & $12 . \mathrm{a}$ & 12.b & 12.c & 합계 \\
\hline ACHPR & $\begin{array}{l}\text { 인권 } \\
\text { (기본권) }\end{array}$ & 2 & 12 & - & 4 & 6 & - & - & 4 & - & - & 12 & 40 \\
\hline $\begin{array}{l}\text { ACHPR Protocol on } \\
\text { Women's Rights }\end{array}$ & $\begin{array}{l}\text { 인권 } \\
\text { (기본권) }\end{array}$ & 8 & 8 & - & 6 & 6 & - & - & 8 & - & - & 9 & 45 \\
\hline $\mathrm{ACHR}$ & 인권(인권) & - & - & - & 2 & & - & - & 4 & - & - & - & 6 \\
\hline ACRWC & $\begin{array}{c}\text { 인권 } \\
\text { (아동권리) }\end{array}$ & - & 4 & - & - & 2 & - & - & - & - & - & - & 6 \\
\hline ADRDM & $\begin{array}{c}\text { 인권 } \\
\text { (인권과 의무) }\end{array}$ & - & - & - & 2 & - & - & - & 4 & - & - & 3 & 9 \\
\hline Basel C & 환경(환경) & - & - & - & 2 & 4 & - & - & - & 24 & - & - & 30 \\
\hline CBD & $\begin{array}{c}\text { 환경 } \\
\text { (생물다양성) }\end{array}$ & 18 & 26 & - & - & - & 10 & - & 28 & - & - & - & 82 \\
\hline CEDAW & 인권(여성) & - & - & - & - & - & - & - & 6 & - & - & - & 6 \\
\hline CRPD & 인권(장애) & - & - & - & - & - & - & - & 20 & - & - & - & 20 \\
\hline ECHR & 인권(기본권) & - & - & - & - & - & - & - & 2 & - & - & - & 2 \\
\hline $\begin{array}{l}\text { Framework } \\
\text { on Minorities }\end{array}$ & $\begin{array}{c}\text { 인권 } \\
\text { (소수민족) }\end{array}$ & - & - & - & - & - & - & - & 2 & - & - & - & 2 \\
\hline ICCPR & 권(정치권) & - & 2 & - & - & - & - & - & 4 & - & - & - & 6 \\
\hline ICESCR & 인권(사회권) & - & 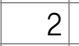 & 6 & 4 & 4 & - & - & 4 & 15 & - & 6 & 41 \\
\hline ILO 169 & $\begin{array}{l}\text { 노동(토착민, } \\
\text { 부족민) }\end{array}$ & - & 6 & - & - & - & - & - & - & - & - & - & 6 \\
\hline ILO 172 & $\begin{array}{l}\text { 노동(근로조건 } \\
\text {-호텔, 식당) }\end{array}$ & - & - & - & - & - & - & - & - & - & 3 & - & 3 \\
\hline ILO Rec 189 & $\begin{array}{c}\text { 노동 } \\
\text { (중소기업) }\end{array}$ & - & - & - & - & - & - & - & - & - & 3 & - & 3 \\
\hline Paris Agre & $\begin{array}{c}\text { 환경 } \\
\text { (기후변화) }\end{array}$ & - & 6 & - & - & - & - & - & - & - & - & 6 & 12 \\
\hline $\begin{array}{l}\text { Protoco } \\
\text { Salvadc }\end{array}$ & 인권(사회권) & - & 4 & 2 & 10 & 6 & - & - & 2 & 9 & - & 9 & 42 \\
\hline UDHR & 인권 & - & - & - & - & - & - & - & 8 & 6 & - & - & 14 \\
\hline $\begin{array}{l}\text { UN Convention on } \\
\text { the Law of the Sea }\end{array}$ & 환경(환경) & - & 2 & - & 30 & - & - & - & - & - & - & - & 32 \\
\hline $\begin{array}{l}\text { UN Convention to } \\
\text { Combat Desertification }\end{array}$ & $\begin{array}{c}\text { 환경 } \\
\text { (생물다양성) }\end{array}$ & - & 16 & - & - & - & - & - & - & - & - & - & 16 \\
\hline UNDRIP & 인권(원주민) & - & 6 & - & 4 & 4 & - & - & 2 & & 12 & - & 28 \\
\hline UNFCCC & $\begin{array}{c}\text { 환경 } \\
\text { (기후변화) }\end{array}$ & 12 & - & - & - & - & - & - & - & - & - & - & 12 \\
\hline UNGP & $\begin{array}{c}\text { 인권 } \\
\text { (기업인권) }\end{array}$ & - & - & - & - & - & 4 & 6 & - & - & - & - & 10 \\
\hline 합계 & & 40 & 94 & 8 & 64 & 32 & 14 & 6 & 98 & 54 & 18 & 45 & 473 \\
\hline
\end{tabular}


- SDG13: 기후변화와 그 영향에 대응하는 긴급행동

- SDG13 세부목표 중 인권기준 반영률: $100 \%$

\begin{tabular}{|c|c|c|c|c|c|c|c|}
\hline \multirow{2}{*}{ 국제인권기준 } & \multirow{2}{*}{ 세부주제 } & \multicolumn{6}{|c|}{ SDG13 세부목표(targets) } \\
\hline & & 13.1 & 13.2 & 13.3 & 13.a & 13.b & 합계 \\
\hline ACHPR & 인권(기본권) & 4 & 2 & 8 & 3 & 24 & 41 \\
\hline $\begin{array}{l}\text { ACHPR Protocol on } \\
\text { Women's Rights }\end{array}$ & 인권(기본권) & 4 & 2 & 4 & - & - & 10 \\
\hline $\mathrm{ACHR}$ & 인권(인권) & 2 & - & 2 & - & - & 4 \\
\hline ACRWC & 인권(아동권리) & 4 & - & 8 & - & 6 & 18 \\
\hline ADRDM & $\begin{array}{c}\text { 인권 } \\
\text { (인권과 의무) }\end{array}$ & 2 & - & 4 & - & - & 6 \\
\hline CBD & $\begin{array}{c}\text { 환경 } \\
\text { (생물다양성) }\end{array}$ & 4 & 20 & - & - & - & 24 \\
\hline CEDAW & 인권(여성) & - & - & 10 & - & 12 & 22 \\
\hline $\begin{array}{l}\text { Convention of Belém } \\
\text { do Pará }\end{array}$ & 인권(여성) & 4 & - & - & - & - & 4 \\
\hline CRC & 인권(아동) & 6 & - & 2 & - & 3 & 11 \\
\hline CRPD & 인권(장애) & 4 & - & 22 & - & 24 & 50 \\
\hline DEVAW & 인권(여성폭력) & 2 & - & & - & - & 2 \\
\hline ECHR & 인권(기본권) & & - & 2 & - & 3 & 5 \\
\hline $\begin{array}{l}\text { Framework Convention } \\
\text { on Minorities }\end{array}$ & 인권(소수민족) & - & - & 2 & - & - & 2 \\
\hline ICCPR & 인권(정치권) & 2 & - & 8 & - & 12 & 22 \\
\hline ICERD & 인권(인종차별) & & - & 2 & - & 3 & 5 \\
\hline ICESCR & 인권(사회권) & 2 & - & 4 & 3 & 21 & 30 \\
\hline ICRMW & $\begin{array}{c}\text { 인권 } \\
\text { (이주노동자) }\end{array}$ & 2 & - & 10 & - & 15 & 27 \\
\hline Paris Agreement & 환경(기후변화) & 2 & 2 & 2 & 3 & 3 & 12 \\
\hline $\begin{array}{l}\text { Protocol of San } \\
\text { Salvador }\end{array}$ & 인권(사회권) & 4 & 4 & 4 & - & 3 & 15 \\
\hline UDHR & 인권 & 2 & & 10 & - & 9 & 21 \\
\hline $\begin{array}{l}\text { UN Convention to } \\
\text { Combat Desertification }\end{array}$ & $\begin{array}{c}\text { 환경 } \\
\text { (생물다양성) }\end{array}$ & 22 & 2 & - & - & - & 24 \\
\hline UNDRIP & 인권(원주민) & 2 & & 6 & - & 6 & 14 \\
\hline UNFCCC & 환경(기후변화) & 2 & 2 & 2 & 6 & 6 & 18 \\
\hline 합계 & & 76 & 34 & 112 & 15 & 150 & 387 \\
\hline
\end{tabular}


- SDG14: 지속가능발전을 위한 대양, 바다, 해양자원의 보존과 지속가능한 사용

- SDG14 세부목표 중 인권기준 반영률: $100 \%$

\begin{tabular}{|c|c|c|c|c|c|c|c|c|c|c|c|c|}
\hline \multirow{2}{*}{ 국제인권기준 } & \multirow{2}{*}{ 세부주제 } & \multicolumn{11}{|c|}{ SDG14 세부목표(targets) } \\
\hline & & 14.1 & 14.2 & 14.3 & 14.4 & 14.5 & 14.6 & 14.7 & 14.a & 14.B & 14.c & 합계 \\
\hline ACHPR & 인권(기본권) & 6 & 4 & 6 & 2 & 2 & 2 & 2 & 3 & 3 & 9 & 39 \\
\hline $\begin{array}{l}\text { ACHPR Proto } \\
\text { Women's Rig }\end{array}$ & 인권(기본권) & 6 & 2 & 2 & - & 2 & - & - & - & - & 9 & 21 \\
\hline ADRDM & $\begin{array}{c}\text { 인권 } \\
\text { (인권과 의무) }\end{array}$ & 2 & - & - & - & - & - & - & 3 & - & - & 5 \\
\hline CBD & $\begin{array}{c}\text { 환경 } \\
\text { (생물다양성) }\end{array}$ & 22 & 92 & 20 & 34 & 28 & 12 & 16 & 33 & 15 & - & 272 \\
\hline ICCPR & 인권(정치권) & - & 2 & - & - & - & 2 & 2 & - & - & 3 & 9 \\
\hline ICESCR & 인권(사회권) & 4 & 4 & 4 & 8 & & 2 & 2 & 12 & - & 3 & 39 \\
\hline ILO 111 & $\begin{array}{c}\text { 노동 } \\
\text { (고용차별) }\end{array}$ & - & - & - & - & - & - & - & - & 3 & - & 3 \\
\hline ILO 188 & $\begin{array}{c}\text { 노동 } \\
\text { (어선근로) }\end{array}$ & - & - & - & - & - & - & - & - & 3 & 3 & 6 \\
\hline MLC & $\begin{array}{c}\text { 노동 } \\
\text { (해사노동) }\end{array}$ & - & - & - & - & - & - & - & - & - & 3 & 3 \\
\hline $\begin{array}{l}\text { Protocol of San } \\
\text { Salvador }\end{array}$ & 인권(사회권) & 4 & 4 & 4 & 2 & 2 & 2 & - & 12 & - & 3 & 33 \\
\hline Ramsar convention & $\begin{array}{c}\text { 환경 } \\
\text { (생물다양성) }\end{array}$ & - & 12 & - & - & 12 & - & - & - & - & - & 24 \\
\hline $\begin{array}{l}\text { UN Convention on } \\
\text { the Law of the Sea }\end{array}$ & 환경(환경) & 58 & 20 & 24 & 50 & 12 & - & 2 & 30 & - & 3 & 199 \\
\hline $\begin{array}{l}\text { UN Convention to } \\
\text { Combat Desertification }\end{array}$ & $\begin{array}{c}\text { 환경 } \\
\text { (생물다양성) }\end{array}$ & - & - & - & - & 14 & - & - & - & - & - & 14 \\
\hline UNDRIP & 인권(원주민) & - & 6 & - & - & 2 & - & - & - & 6 & - & 14 \\
\hline UNFCCC & $\begin{array}{c}\text { 환경 } \\
\text { (기후변화) }\end{array}$ & - & 10 & - & - & - & - & - & - & - & - & 10 \\
\hline 합계 & & 102 & 156 & 60 & 96 & 74 & 20 & 24 & 93 & 30 & 36 & 691 \\
\hline
\end{tabular}


- SDG15: 육상 생태계의 보호, 복원 및 지속가능한 사용 증진, 삼림의 지속가능한 관리, 사막화 방지, 토지 황폐화 방지와 복구 및 생물다양성 손실 방지

- SDG15 세부목표 중 인권기준 반영률: $100 \%$

\begin{tabular}{|c|c|c|c|c|c|c|c|c|c|c|c|c|c|c|}
\hline \multirow{2}{*}{ 국제인권기준 } & \multirow{2}{*}{ 세부주제 } & \multicolumn{13}{|c|}{ SDG15 세부목표(targets) } \\
\hline & & 15.1 & 15.2 & 15.3 & 15.4 & 15.5 & 15.6 & 15.7 & 15.8 & 15.9 & $15 . a$ & $15 . b$ & $15 . c$ & 합계 \\
\hline ACHPR & 인권(기본권) & 8 & 8 & 6 & 6 & 6 & 4 & - & - & 4 & 6 & 6 & 6 & 60 \\
\hline $\begin{array}{l}\text { ACHPR } \\
\text { Women's }\end{array}$ & 인권(기본권) & 6 & 6 & 6 & 6 & 6 & 6 & - & - & - & 9 & 6 & 6 & 57 \\
\hline ACHR & 인권(인권) & - & - & - & - & - & 2 & - & - & - & - & - & - & 2 \\
\hline CBD & $\begin{array}{c}\text { 환경 } \\
\text { (생물다양성) }\end{array}$ & 100 & 104 & - & 90 & 90 & 14 & 14 & 6 & 16 & 30 & 30 & 21 & 515 \\
\hline ICCPR & 인권(정치권) & 2 & 2 & 2 & 2 & 2 & - & - & - & - & - & - & - & 10 \\
\hline ICESCR & 인권(사회권) & 6 & 6 & 6 & 6 & 6 & 4 & - & - & - & 18 & 18 & - & 70 \\
\hline NAGOYA & $\begin{array}{c}\text { 환경 } \\
\text { (생물다양성) }\end{array}$ & - & - & - & - & - & 2 & - & - & - & - & - & - & 2 \\
\hline Paris Agreement & 환경(기후변화) & 2 & 6 & - & - & - & - & - & - & - & - & 3 & - & 11 \\
\hline $\begin{array}{l}\text { Protocol of San } \\
\text { Salvador }\end{array}$ & 인권(사회권) & 4 & 2 & 2 & 2 & 2 & 2 & 2 & 2 & - & 3 & 3 & 3 & 27 \\
\hline Ramsar convention & $\begin{array}{c}\text { 환경 } \\
\text { (생물다양성) }\end{array}$ & 2 & - & - & - & 12 & - & 2 & 2 & 2 & - & - & - & 20 \\
\hline UDHR & 인권 & - & - & - & - & - & - & - & - & - & 6 & 6 & - & 12 \\
\hline $\begin{array}{l}\text { UN Convention to } \\
\text { Combat Desertification }\end{array}$ & $\begin{array}{c}\text { 환경 } \\
\text { (생물다양성) }\end{array}$ & 14 & 4 & 2 & 6 & 16 & - & - & - & 2 & - & - & - & 44 \\
\hline UNDRIP & 인권(원주민) & 8 & 8 & 8 & 8 & 8 & 2 & - & - & - & 3 & 3 & 6 & 54 \\
\hline UNFCCC & 환경(기후변화) & 10 & 10 & 10 & - & - & - & - & - & - & - & 6 & & 36 \\
\hline 합계 & & 162 & 156 & 42 & 126 & 148 & 36 & 18 & 10 & 24 & 75 & 81 & 42 & 920 \\
\hline
\end{tabular}


- SDG16: 지속가능발전을 위한 평화롭고 포용적인 사회 증진 모두에게 정의에 대한 접근성 제공, 모든 수준에서 효과적이고 책무성있고 포용적인 제도 구축

- SDG16 세부목표 중 인권기준 반영률: $100 \%$

\begin{tabular}{|c|c|c|c|c|c|c|c|c|c|c|c|c|c|c|}
\hline \multirow{2}{*}{ 국제인권기준 } & \multirow{2}{*}{ 세부주제 } & \multicolumn{13}{|c|}{ SDG16 세부목표(targets) } \\
\hline & & 16.1 & 16.2 & 16.3 & 16.4 & 16.5 & 16.6 & 16.7 & 16.8 & 16.9 & 16.10 & 16.a & 16.b & 합계 \\
\hline ACHPR & 인권(기본권) & 6 & 6 & 20 & 8 & - & 4 & 4 & - & 4 & 10 & 3 & 24 & 89 \\
\hline $\begin{array}{l}\text { ACHPR } \\
\text { Protocol on } \\
\text { Women's } \\
\text { Rights }\end{array}$ & 인권(기본권) & 18 & 18 & 20 & - & - & 8 & 22 & - & 2 & - & 3 & 33 & 124 \\
\hline ACHR & 인권(인권) & 2 & 8 & 54 & - & - & 8 & 10 & - & 10 & 6 & - & 9 & 107 \\
\hline ACRWC & $\begin{array}{c}\text { 인권 } \\
\text { (아동권리) }\end{array}$ & 14 & 22 & 26 & - & - & 2 & 2 & - & 4 & 6 & - & 9 & 85 \\
\hline ADRDM & $\begin{array}{c}\text { 인권 } \\
\text { (인권과 의무) }\end{array}$ & 2 & 2 & 8 & - & - & 2 & 2 & - & 4 & 2 & - & 3 & 25 \\
\hline CAT & $\begin{array}{c}\text { 인권 } \\
\text { (고문방지) }\end{array}$ & - & 2 & - & - & - & - & - & - & - & 2 & - & - & 4 \\
\hline CBD & $\begin{array}{c}\text { 환경 } \\
\text { (생물다양성) }\end{array}$ & - & - & - & - & - & - & 8 & - & - & - & - & - & 8 \\
\hline CEDAW & 인권(여성) & - & 2 & 4 & - & - & 2 & 6 & - & 4 & - & - & 57 & 75 \\
\hline $\begin{array}{l}\text { Convention of } \\
\text { Bel챕m do } \\
\text { Par찼 }\end{array}$ & 인권(여성) & 2 & 8 & 6 & - & - & - & - & - & - & 2 & - & - & 18 \\
\hline CPPCG & $\begin{array}{c}\text { 인권 } \\
\text { (집단살해죄) }\end{array}$ & 2 & - & - & - & - & - & - & - & - & - & - & - & 2 \\
\hline $\mathrm{CRC}$ & 인권(아동) & 12 & 18 & 2 & - & - & 2 & 2 & - & 4 & 14 & - & 21 & 75 \\
\hline CRPD & 인권(장애) & 8 & 8 & 4 & - & - & - & 2 & - & 6 & 8 & - & 24 & 60 \\
\hline CTOC & $\begin{array}{c}\text { 노동 } \\
\text { (조직범죄) }\end{array}$ & - & 2 & & 2 & - & - & - & - & - & - & - & - & 4 \\
\hline DEVAW & $\begin{array}{c}\text { 인권 } \\
\text { (여성폭력) }\end{array}$ & 2 & - & - & - & - & - & - & - & - & 2 & - & - & 4 \\
\hline ECHR & 인권(기본권) & 4 & 6 & 42 & - & - & - & - & - & - & 6 & - & 3 & 61 \\
\hline ECHR Protocol & 인권(기본권) & - & - & - & - & - & - & 2 & - & - & - & - & - & 2 \\
\hline $\begin{array}{l}\text { ECHR Protocol } \\
\text { No. } 12\end{array}$ & 인권(기본권) & - & - & - & - & - & - & - & - & - & - & - & 6 & 6 \\
\hline $\begin{array}{l}\text { ECHR Protocol } \\
\text { No. } 4\end{array}$ & 인권(기본권) & - & 2 & - & - & - & - & - & - & - & - & - & - & 2 \\
\hline $\begin{array}{l}\text { ECHR Protocol } \\
\text { No. } 6\end{array}$ & 인권(기본권) & - & - & 2 & - & - & - & - & - & - & - & - & - & 2 \\
\hline $\begin{array}{l}\text { ECHR Protocol } \\
\text { No. } 7\end{array}$ & 인권(기본권) & - & - & 20 & - & - & - & - & - & - & - & - & - & 20 \\
\hline $\begin{array}{l}\text { Framework } \\
\text { Convention on } \\
\text { Minorities }\end{array}$ & $\begin{array}{c}\text { 인권 } \\
\text { (소수민족) }\end{array}$ & 2 & 2 & 2 & - & - & 2 & 2 & - & 4 & 10 & - & 9 & 33 \\
\hline ICCPR & 인권(정치권) & 6 & 10 & 34 & - & - & 2 & 6 & 2 & 4 & 10 & 3 & 15 & 92 \\
\hline
\end{tabular}

\section{제 I 장}

제II장

제III장 
Journal of International Development Cooperation

\begin{tabular}{|c|c|c|c|c|c|c|c|c|c|c|c|c|c|c|}
\hline \multirow{2}{*}{ 국제인권기준 } & \multirow{2}{*}{ 세부주제 } & \multicolumn{13}{|c|}{ SDG16 세부목표(targets) } \\
\hline & & 16.1 & 16.2 & 16.3 & 16.4 & 16.5 & 16.6 & 16.7 & 16.8 & 16.9 & 16.10 & $16 . a$ & $16 . b$ & 합계 \\
\hline ICERD & $\begin{array}{c}\text { 인권 } \\
\text { (인종차별) }\end{array}$ & 2 & 2 & 4 & - & - & 2 & 2 & - & 2 & 6 & - & 21 & 41 \\
\hline ICESCR & 인권(사회권) & - & 2 & & - & 2 & 2 & - & 2 & - & - & 3 & 15 & 26 \\
\hline ICPPED & $\begin{array}{c}\text { 인권 } \\
\text { (실종방지) }\end{array}$ & 8 & - & - & - & - & - & - & - & - & 8 & - & - & 16 \\
\hline ICRMW & $\begin{array}{c}\text { 인권 } \\
\text { (이주노동자) }\end{array}$ & 8 & 10 & - & - & - & - & 10 & - & - & 10 & - & 15 & 53 \\
\hline ILO 102 & $\begin{array}{l}\text { 노동(노동 } \\
\text { 최저기준) }\end{array}$ & - & - & - & - & - & - & - & - & - & - & - & 3 & 3 \\
\hline ILO 105 & $\begin{array}{c}\text { 노동 } \\
\text { (강제근로) }\end{array}$ & - & 2 & - & - & - & - & - & - & - & - & - & - & 2 \\
\hline ILO 111 & $\begin{array}{c}\text { 노동 } \\
\text { (고용차별) }\end{array}$ & - & - & - & - & - & - & - & - & - & - & - & 3 & 3 \\
\hline ILO 118 & $\begin{array}{c}\text { 노동 } \\
\text { (균등대우) }\end{array}$ & - & - & - & - & - & - & - & - & - & - & - & 3 & 3 \\
\hline ILO 143 & $\begin{array}{c}\text { 노동 } \\
\text { (이주근로자) }\end{array}$ & - & 2 & - & - & - & - & - & - & - & - & - & - & 2 \\
\hline ILO 181 & $\begin{array}{c}\text { 노동 } \\
\text { (직업소개소) }\end{array}$ & - & 2 & - & - & - & - & - & - & - & - & - & - & 2 \\
\hline ILO 182 & $\begin{array}{c}\text { 노동 } \\
\text { (아동노동) }\end{array}$ & - & 2 & - & - & - & - & - & - & - & - & - & - & 2 \\
\hline ILO 29 & $\begin{array}{c}\text { 노동 } \\
\text { (강제근로) }\end{array}$ & - & 2 & - & - & - & - & - & - & - & - & - & - & 2 \\
\hline ILO 97 & $\begin{array}{c}\text { 노동 } \\
\text { (취업이주) }\end{array}$ & - & 2 & - & - & - & - & - & - & - & - & - & - & 2 \\
\hline ILO Protocol 29 & $\begin{array}{c}\text { 노동 } \\
\text { (강제근로) }\end{array}$ & - & 2 & - & - & - & - & - & - & - & - & - & - & 2 \\
\hline ILO Rec 151 & $\begin{array}{c}\text { 노동 } \\
\text { (이주근로자) }\end{array}$ & - & 2 & - & - & - & - & - & - & - & - & - & - & 2 \\
\hline ILO Rec 202 & $\begin{array}{c}\text { 노동 } \\
\text { (사회적보장) }\end{array}$ & - & - & - & - & - & - & - & - & - & - & - & 3 & 3 \\
\hline ILO Rec 203 & $\begin{array}{c}\text { 노동 } \\
\text { (강제근로) }\end{array}$ & - & 2 & - & - & - & - & - & - & - & - & - & - & 2 \\
\hline ILO Rec 86 & $\begin{array}{c}\text { 노동 } \\
\text { (취업이주) }\end{array}$ & - & 2 & - & - & - & - & - & - & - & - & - & - & 2 \\
\hline IACDPD & $\begin{array}{c}\text { 인권 } \\
\text { (장애인) }\end{array}$ & - & - & - & - & - & 10 & 2 & - & - & - & - & - & 12 \\
\hline $\begin{array}{l}\text { Protocol of San } \\
\text { Salvador }\end{array}$ & 인권(사회권) & - & 6 & - & - & - & - & - & - & - & - & - & 9 & 15 \\
\hline UDHR & 인권 & 4 & 6 & 8 & - & - & - & 2 & 2 & 2 & 8 & - & 15 & 47 \\
\hline UNCAC & 인권(반부패) & - & - & - & - & 2 & - & - & - & - & - & - & - & 2 \\
\hline UNDRIP & 인권(원주민) & 6 & 8 & - & - & - & - & 4 & - & 4 & 6 & - & 21 & 49 \\
\hline UNFCCC & $\begin{array}{c}\text { 환경 } \\
\text { (기후변화) }\end{array}$ & - & - & - & - & - & - & 20 & - & - & - & - & - & 20 \\
\hline 합 & & 108 & 170 & 256 & 10 & 4 & 46 & 108 & 6 & 54 & 116 & 12 & 321 & 1,211 \\
\hline
\end{tabular}


- SDG17: 이행수단 강화와 지속가능발전을 위한 글로벌 파트너십 활성화

- SDG17 세부목표 중 인권기준 반영률: $100 \%$

\begin{tabular}{|c|c|c|c|c|c|c|c|c|c|c|c|c|c|c|c|c|c|c|c|c|c|}
\hline \multirow{2}{*}{ 국제인권기준 } & \multirow{2}{*}{ 세부주제 } & \multicolumn{20}{|c|}{ SDG17 세부목표 } \\
\hline & & \begin{tabular}{l|l}
17.1 & 1
\end{tabular} & 17.2 & 17.3 & 17.4 & 17.5 & 17.6 & 17.7 & 17.8 & 17.9 & 17.101 & 17.111 & 17.12 & 17.131 & 17.141 & 17.15 & 17.161 & 17.171 & 17.18 & 17.19 & 합계 \\
\hline ACHPR & $\begin{array}{c}\text { 인권 } \\
\text { (기본권) }\end{array}$ & 6 & - & - & - & - & 4 & 4 & 4 & 2 & 4 & - & - & - & 6 & - & 4 & 2 & - & 4 & 40 \\
\hline $\begin{array}{l}\text { ACHPR Protocol on } \\
\text { Women's Rights }\end{array}$ & $\begin{array}{l}\text { 인권 } \\
\text { (기본권) }\end{array}$ & - & - & - & - & - & - & 4 & - & - & - & - & - & - & 4 & - & - & - & - & - & 8 \\
\hline $\mathrm{ACHR}$ & $\begin{array}{l}\text { 인권 } \\
\text { (인권) }\end{array}$ & 2 & - & - & - & - & - & - & - & - & 2 & 2 & - & - & - & - & - & 2 & 2 & - & 8 \\
\hline ACRWC & $\begin{array}{c}\text { 인권 } \\
\text { (아동권리) }\end{array}$ & - & - & - & - & - & - & - & - & - & - & - & - & - & - & - & - & - & 2 & - & 2 \\
\hline Basel Convention & 환경(환경) & - & - & 4 & - & - & - & 14 & - & 6 & - & - & - & - & - & - & - & - & & - & 24 \\
\hline CEDAW & 인권(여성) & - & - & - & - & - & - & & 2 & - & - & - & - & - & - & - & - & - & 2 & - & 4 \\
\hline CRC & 인권(아동) & - & - & - & - & - & - & 2 & - & - & - & - & - & - & - & - & - & - & 2 & - & 4 \\
\hline CRPD & 인권(장애) & - & - & - & - & - & 10 & 2 & 16 & - & - & - & - & - & - & - & - & - & 10 & - & 38 \\
\hline ECHR & $\begin{array}{c}\text { 인권 } \\
\text { (기본권) }\end{array}$ & - & - & - & - & - & 2 & - & - & - & - & - & - & - & - & - & - & - & - & - & 2 \\
\hline $\begin{array}{l}\text { Framework } \\
\text { Convention on } \\
\text { Minorities }\end{array}$ & $\begin{array}{c}\text { 인권 } \\
\text { (소수민족) }\end{array}$ & - & - & - & - & - & 2 & - & 2 & - & - & - & - & - & - & - & - & - & - & - & 4 \\
\hline ICCPR & $\begin{array}{c}\text { 인권 } \\
\text { (정치권) }\end{array}$ & - & - & - & - & 2 & 2 & - & 4 & 2 & & 2 & 2 & 2 & - & 2 & - & - & 4 & 2 & 26 \\
\hline ICERD & $\begin{array}{c}\text { 인권 } \\
\text { (인종차별) }\end{array}$ & - & - & - & - & - & - & - & - & - & - & - & - & - & - & - & - & - & 2 & - & 2 \\
\hline ICESCR & $\begin{array}{c}\text { 인권 } \\
\text { (사회권) }\end{array}$ & 4 & 4 & 4 & 2 & 2 & 10 & 12 & 8 & 2 & 4 & 4 & 4 & 4 & - & 2 & 6 & - & 2 & 4 & 78 \\
\hline ICRMW & $\begin{array}{c}\text { 인권(이주 } \\
\text { 노동자) }\end{array}$ & - & - & - & - & - & - & - & - & - & - & - & - & - & - & - & - & - & 2 & - & 2 \\
\hline IACDPD & $\begin{array}{c}\text { 인권 } \\
\text { (장애인) }\end{array}$ & - & - & - & - & - & - & - & - & - & - & - & - & - & - & - & - & - & 2 & - & 2 \\
\hline Paris Agreement & $\begin{array}{c}\text { 환경 } \\
\text { (기후변화) }\end{array}$ & - & - & 4 & - & - & 6 & - & - & - & - & - & - & - & - & - & - & - & - & - & 10 \\
\hline $\begin{array}{l}\text { Protocol of San } \\
\text { Salvador }\end{array}$ & $\begin{array}{c}\text { 인권 } \\
\text { (사회권) }\end{array}$ & - & - & - & - & - & 2 & - & - & - & - & - & - & - & - & - & - & - & 2 & - & 4 \\
\hline UDHR & 인권 & 2 & 2 & 2 & 2 & 2 & 6 & 4 & 6 & 2 & 2 & 2 & 2 & 2 & - & - & 2 & & 4 & - & 42 \\
\hline $\begin{array}{l}\text { UN Convention on } \\
\text { the Law of the Sea }\end{array}$ & 환경(환경) & - & - & - & - & - & 20 & - & - & - & - & - & - & - & - & - & - & - & - & - & 20 \\
\hline UNDRIP & $\begin{array}{c}\text { 인권 } \\
\text { (원주민) }\end{array}$ & - & - & 2 & - & - & - & - & - & - & - & - & - & - & - & - & - & - & - & - & 2 \\
\hline UNFCCC & $\begin{array}{c}\text { 환경 } \\
\text { (기후변화) }\end{array}$ & - & - & 6 & - & - & 4 & 4 & - & - & - & - & - & - & 4 & - & - & - & - & - & 18 \\
\hline UNGP & $\begin{array}{c}\text { 인권 } \\
\text { (기업인권) }\end{array}$ & - & - & 4 & - & 4 & - & - & - & - & - & - & - & - & - & - & - & 4 & - & - & 12 \\
\hline 합계 & & 14 & 6 & 26 & 4 & 10 & 68 & 46 & 42 & 14 & 12 & 10 & 8 & 8 & 14 & 4 & 12 & 8 & 36 & 10 & 352 \\
\hline
\end{tabular}




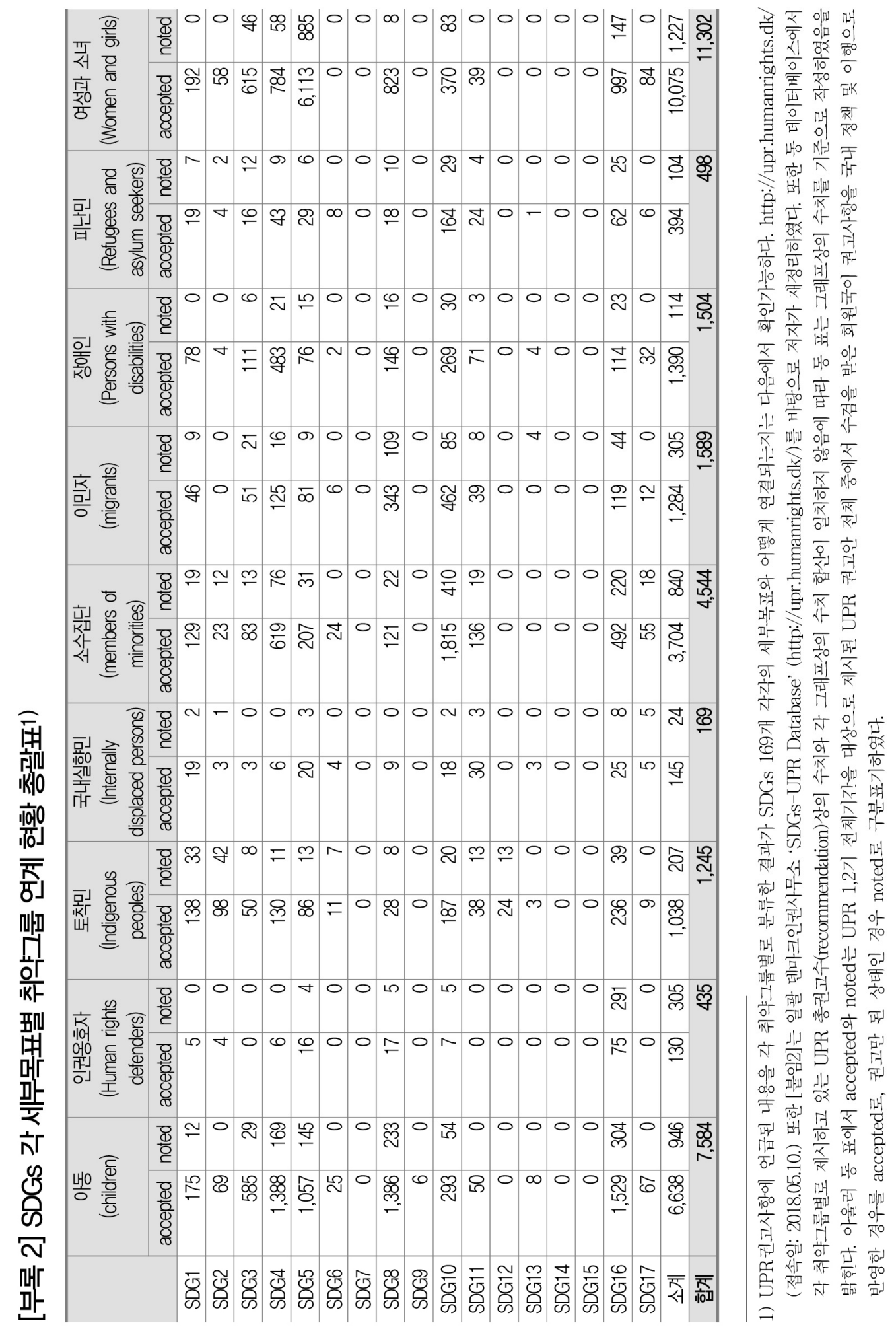

